\title{
Abhandlung
}

Angela Kreuz, Tanja Märkle, Elena Marinova, Manfred Rösch, Eva Schäfer, Silke Schamuhn, Tanja Zerl

\section{The Late Neolithic Michelsberg culture - just ramparts and ditches? A supraregional comparison of agricultural and environmental data}

\begin{abstract}
Der archäobotanische Forschungsstand zur Michelsberger und zur Bischheimer Kultur (5./4. Jahrtausend BC) wurde zusammengetragen und in Zusammenhang mit archäologischen, klimatologischen und biologischen Daten diskutiert. Verglichen mit Bischheim und dem Mittelneolithikum hat die Michelsberger Kultur ein reduziertes Kulturpflanzenspektrum genutzt, mit einem Schwerpunkt bei Getreideanbau. Die Herkunft des tetraploiden Nacktweizens konnte dabei noch nicht abschließend geklärt werden. Möglicherweise wurde der Anbau von Öl-/ Faserpflanzen aufgegeben. Dieses reduzierte Michelsberger Spektrum findet sich interessanterweise etwas später analog im Verbreitungsgebiet der Trichterbecherkultur und bei den neolithischen Fundstellen auf den britischen Inseln. Klimatische Ursachen sind dafür wohl nicht als ursächlich anzusehen. Stattdessen könnte es sich nach den vegetationsgeschichtlichen und archäozoologischen
\end{abstract}

Prof. Dr. Angela Kreuz, Archäologische und Paläontologische Denkmalpflege, Landesamt für Denkmalpflege Hessen, hessenARCHÄOLOGIE, Schloß Biebrich/Ostflügel, D-65203 Wiesbaden. E-Mail: a.kreuz@hessen-archaeologie.de

Tanja Märkle M. A., Landesamt für Denkmalpflege, Fischersteig 9, D-78343 Gaienhofen-Hemmenhofen. E-Mail: tanja.maerkle@rps. bwl.de

PD Dr. Elena Marinova, Royal Belgian Institute for Natural Sciences, Rue Vautier 29, B-1000 Brüssel. E-Mail: elena.marinova@ naturalsciences.be

Prof. Dr. Manfred Rösch, Landesamt für Denkmalpflege, Fischersteig 9, D-78343 Gaienhofen-Hemmenhofen. E-Mail: Manfred.roesch@rps.bwl.de

Dr. Eva Schäfer, Archäologische und Paläontologische Denkmalpflege, Landesamt für Denkmalpflege Hessen, hessenARCHÄOLOGIE, Schloß Biebrich/Ostflügel, D-65203 Wiesbaden. E-Mail: e.schaefer@hessen-archaeologie.de

Silke Schamuhn M. A., Labor für Archäobotanik, Institut für Ur- und Frühgeschichte, Universität zu Köln, Weyertal 125, D-50923 Köln. E-Mail: schamuhn@netcologne.de

Tanja Zerl M. A., Labor für Archäobotanik, Institut für Ur- und Frühgeschichte, Universität zu Köln, Weyertal 125, D-50923 Köln. E-Mail: tzerl@uni-koeln.de
Ergebnissen um eine kulturelle Entscheidung zu einem Landwirtschaftssystem mit Schwerpunkt bei der Viehzucht handeln.

Keywords: Westliches Mitteleuropa; Neolithikum; Bischheim; Michelsberg; Erdwerke; tetraploider Nacktweizen; reduziertes Kulturpflanzenspektrum.

Résumé: Les données carpologiques issues des sites de la culture Michelsberg et du complexe culturel de Bischheim $\left(5^{\text {th }} / 4^{\text {th }}\right.$ millénaire $\left.\mathrm{BC}\right)$ provenant de la France, de Belgique, du Pays-Bas et de l'Allemagne ont été mises en perspective avec des données archéologiques, climatologiques et des données biologiques. Au contraire des cultures archéologiques du complexe Bischheim et du Néolithique moyen les communautés paysannes du Michelsberg commençaient à cultiver un spectre des plantes réduit. Les résultats archéobotaniques rendent possible la reconstruction d'un mode de subsistance avec une orientation des activités vers l'élevage. Des changements importants viennent de l'exploitation surtout des céréales et peu des légumineuses et l'abandon de la culture des plantes oléagineuses, un spectre qui se retrouve également un peu plus tard dans la région de la Culture des vases à entonnoir et du Néolithique en Angleterre et en Irlande. Les recherches futures devront s'attacher à vérifier cette hypothèse. Peutêtre est-ce un exemple d'une décision culturelle comme adaptation aux changements des besoins et des structures sociales?

Mots-clefs: Europe du centre-ouest; Néolithique; Bischheim; Michelsberg; camps à fossés interrompus; blé nu tétraploïde; spectre de plantes cultivées réduit.

Abstract: The archaeobotanical state of research from sites of the Michelsberg and the Bischheim culture $\left(5^{\text {th }} / 4^{\text {th }}\right.$ millenium BC) in France, Belgium, southern Netherlands and Germany has been compiled and discussed in the 
context of archaeological, climatological and biological data. Compared with Bischheim and the Middle Neolithic the farmers of the Michelsberg culture had a reduced crop spectrum with emphasis on cereal growing. It is still under debate, from where the tetraploid wheat has been introduced. Possibly the growing of oil/fibre plants was abandoned by the Michelsberg farmers. Interestingly the same reduced crop spectrum is found somewhat later in the distribution area of the Funnelbeaker culture as well as in the Neolithic sites of Great Britain and Ireland. Climatic causes are not likely for this phenomenon. Instead, zoologial and botanical results point to an agricultural system with more emphasis on stock farming, which might have been based on a cultural decision.

Keywords: Western Central Europe; Neolithic; Bischheim; Michelsberg; causewayed enclosures; tetraploid naked wheat; reduced crop spectrum.

DOI 10.1515/pz-2014-0006

\section{Introduction}

The Late Neolithic Michelsberg culture belongs to a prehistoric time segment with important cultural changes comprising the neolithisation of north-western Central Europe as well as of the British Isles and parts of the northern Alpine foreland ${ }^{1}$. Recently archaeological and archaeobiological research was conducted within a Franco-German Michelsberg research program co-funded by the ANR (French National Research Agency) and the DFG (German Research Association) entitled "Emergence of social complexity: enclosures, resources and territoriality during the Neolithic"2. To answer the question of the interaction of man and environment, and to discuss the agricultural basis of the Michelsberg culture ${ }^{3}$, in 2012 a workgroup was constituted, with the aim of compiling the archaeological and archaeobotanical state of research and discussing it in a supraregional context ${ }^{4}$. The results are presented in the following.

1 Bradley 2007; Brown 2007; Denaire et al. 2011; Ebersbach et al. 2012; Furholt et al. 2011; Hinz/Müller 2012; Jeunesse et al. 2004; Jöns 2013; Louwe Kooijmans 2005; Schier 1993, 2009; Vanmontfort 2004. 2 http://www.anr-mk-projekt.fr/spip.php?lang=en\&page=sommaire 3 "Culture" is meant here as "archaeological culture", comprising a typical combination of artefacts, archaeological features and archaeobiological finds in a certain distribution area (for the discussion see e.g. Lüning 1972).

4 Kreuz 2012. Participants of the workgroup have been Angela Kreuz and Eva Schäfer (Wiesbaden) for the region of Hesse, Elena Marinova

\section{Archaeology}

The Late Neolithic Michelsberg culture of the loess landscapes in western Central Europe succeeded the Middle Neolithic Rössen culture and the transitional Middle/LateNeolithic Bischheim culture (Fig. 1). Following B. Höhn ${ }^{5}$, Michelsberg phases II-V ${ }^{6}$ probably lasted from about 4380/4340 until 3540/3530 cal BC. The precise dating of the Michelsberg phases is hampered by the plateaus of the calibration curve in the centuries around $4000 \mathrm{cal}$ BC. Bischheim seems to be about 200 years older than Michelsberg, although too few ${ }^{14} \mathrm{C}$-dates are available until now. As defined by Denaire et al., Eisenhauer, Höhn, Jeunesse, Kuhlmann, Schier and Seidel ${ }^{7}$, Bischheim starts at about $4600 / 4550 / 4500$ cal BC, followed by a middle and younger phase until 4450/4420/4350/4300 cal BC ${ }^{8}$.

According to the current archaeological state of research the Michelsberg culture has its primary origin in the Paris Basin in France, or more to the north in the border region of France and Belgium ${ }^{9}$. From there it spread to the Alsace, Belgium, the southern Netherlands, the Lower Rhine Area and further south into Germany. Sites from the earliest Michelsberg phase I are lacking in Hesse until now, for Baden-Württemberg it is still under discussion ${ }^{10}$. Perhaps Michelsberg started several hundred years later in these areas. Both Michelsberg and Bischheim have strong stylistic affinities with the western Chasséen of France ${ }^{11}$.

(Brussels) for Belgium, Manfred Rösch and Tanja Märkle (Hemmenhofen) for Baden-Württemberg, Aurélie Salavert (Paris) for France, Tanja Zerl, Silke Schamuhn and Jutta Meurers-Balke (Cologne) for North Rhine-Westphalia. Charcoal results from France, not included here, have been provided by Aurélie Salavert. Other unpublished archaeobotanical data from France have not been available for this compilation.

5 Höhn 2002, e.g. 193.

6 After Lüning 1967/1968.

7 Denaire et al. 2011; Eisenhauer/Daszkiewicz 2003, 172f., Fig. 4; Höhn 2002, 193; Jeunesse et al. 2004, 75; Kuhlmann 2008, 6; Schier 2009, 20; Seidel 2011.

8 Dating difficulties are apparent among the often high standard deviations of the ${ }^{14} \mathrm{C}$-dates; see also the discussion of the dating of Cerny, Épi-Roessen, Proto-Menneville and Bischheim occidental in Vanmontfort 2004, 285 ff. and 350; Raetzel-Fabian 2006.

9 Badisches Landesmuseum Karlsruhe 2010; Dubouloz 1998, 19; Jeunesse 1998, 42f.; Jeunesse et al. 2004; Knoche 2008, 126; Louwe Kooijmans 2005; Lüning 1967/1968; Schier 1993, 2009, 20; Vanmontfort 2004; more references there.

10 Höhn 2002; Regner-Kamlah 2010; Schlichtherle 1998, 170 ; Seidel 2012 and personal comm. 2013.

11 See references above as well as Gross 1990, $61 \mathrm{ff}$. 
ca. cal BC

Archaeological culture

Wartberg

$3.540 / 3.530$

\section{Neolithic}

Michelsberg

4.380/4.340

- - - - - - - - - - - - - -

$4.450 / 4.420 / 4.350 / 4.300$

\section{Bischheim}

\subsection{0/4.550/4.500}

\section{Rössen}

Großgartach

Hinkelstein

\subsection{0}

\section{Bandkeramik}

\section{Early}

\subsection{0}

Fig. 1: Chronology of the Early to Late Neolithic in the investigation area (absolute datings following Eisenhauer 2003; Geschwinde and Raetzel-Fabian 2009; Höhn 2002; Jeunesse 2004; Jeunesse et al; 2003; Knoche 2008; Kuhlmann 2008; Schier 2009; Seidel 2011; more references there)

More or less monumental causewayed enclosures - consisting of palisades, walls and ditches - are one of the most obvious characteristics of the Michelsberg culture ${ }^{12}$. They are situated either on hilltops or in the lowlands. Regularly the ditches have several interruptions or entrances. In addition, open sites without enclosures occur in the lowlands. At the end of Michelsberg the enclosures

12 Geschwinde/Raetzel-Fabian 2009; Jeunesse/Seidel 2010; Meyer 1992/1993; Seidel 2008; Wotzka 2000. are built preponderantly on hilltops and perhaps developed a more defensive character ${ }^{13}$.

It is still under discussion, which Michelsberg site types represent permanent settlements where people lived. Apart from settlement structures like pits, especially regular houses, of the Michelsberg culture are almost

13 E.g. Biel 1998; Knoche 2008, 151; critical for the Wetterau region: Raetzel-Fabian 2006. 
unknown ${ }^{14}$. Burnt daub with imprints of wood regularly provides evidence for building structures which - in contrast to earlier ones - left almost no traces in the ground and probably were now smaller - implying another form of residential sharing. The tradition of longhouses (Bandkeramik until Rössen) had (gradually? ${ }^{15}$ ) been abandoned by the Bischheim culture ${ }^{16}$. As for Michelsberg village structures, small houses in rows along roads are expected like those that existed before at the southern sites of Bischheim ${ }^{17}$ and at the Neolithic sites of the northern Alpine foreland ${ }^{18}$, but this has not been proven until now. Very few small buildings (partly sunken floor buildings) have been excavated ${ }^{19}$. In addition, 23 extremely large buildings have been uncovered in France at „Haute Chanvières“ Mairy/Ardennes ${ }^{20}$. Three of these have been dated by ${ }^{14} \mathrm{C}$ to a younger Michelsberg phase (before $3800 \mathrm{cal} \mathrm{BC)}$. The character of this completely exceptional site is still under discussion. Unfortunately no archaeobotanical investigations have been conducted there.

As for the burials of the deceased, Michelsberg graves are also almost unknown. Rare exceptions are graves from Hofheim (Hesse), Bad Kreuznach (Rhineland-Palatinate), Stuttgart and Bruchsal (Baden-Württemberg) ${ }^{21}$. Instead, whole human skeletons as well as parts of one or several individuals are found above all in the ditches of the earthworks, but also in related pits.

According to anthropological data, the body height of Michelsberg men was between 1,63-1,75 m, of women $1,55-1,62 \mathrm{~m}^{22}$. Adults reached on average an age of 40 years, but occasionally ages of more than 60 years have also been determined. It appears that there is no differentiation in the deposition of males and females ${ }^{23}$.

14 E.g. Vanmontfort 2004, 312.

15 Three exceptional Bischheim longhouses were found at three sites in the Lower Rhine area only (Arora 2002). One of them is not trapezoid - like the Rössen buildings - but rectangular. The dating of the buildings may be problematic, as other prehistoric periods are represented on the site.

16 E.g. Arora 2005; Herrmann/Jockenhövel 1990; Lüning 1981; Schamuhn in prep.; Schier 1993, 36; Schlichtherle 1988.

17 Biel 1984; Knoche 2008; Rademacher 1991; Schlichtherle 1988; Seidel 2012.

18 Matuschik 2011; Strobel 2000.

19 Examples in: Bergmann 2008; de Grooth 1991, 174; Höhn 2002; Knoche 2008; Richter in prep., 42ff.; Schamuhn in prep.; Zeeb-Lanz 2002, 35.

20 Marolle 1998.

21 Probst 1991, 322; Regner-Kamlah written comm. 13. 5. 2013.

22 Wahl 2010, $97 \mathrm{ff}$.

23 Biel 1998; Herrmann/Jockenhövel 1990; Seidel 2008; 2012; Wahl 2008; 2010.
Based on the typo-chronology of the ceramics the Michelsberg culture is differentiated into five phases following Lüning and Höhn ${ }^{24}$. Several of the Michelsberg ceramic forms existed continuously for hundreds of years. Therefore, a site or a feature is archaeologically well datable only when it has an extensive pottery assemblage. In most cases it is only possible to distinguish between "earlier" and later "Michelsberg". Therefore in the following the archaeobotanical data are differentiated into "Earlier Michelsberg" (MK I and/or II) and "Later Michelsberg" (one or several phases of MK III-V) and "Michelsberg undifferentiated" (transition MK II/III included in this group). This makes sense as there are several changes in the material culture between Michelsberg phase II and IIIff. (e.g. the emergence of flat vessel bottoms, carinated bowls ["Knickwandschüsseln"] and barbotine [“Schlickauftrag”]) $)^{25}$.

Among the lithic finds (fragments of) grind stones indicate the availability of tools for preparing flour from cereals and pulses ${ }^{26}$. Michelsberg sites have produced flint tools of a larger dimensions than earlier in the Early and Middle Neolithic, so that for the first time the raw material had to be obtained from flint mines with shafts and gallery complexes over ten metres below surface ${ }^{27}$. Another lithic speciality are the Michelsberg tools made of mountain crystal $^{28}$. As mountain crystal tools are not very useful from a functional point of view, a metaphoric use in ritual contexts is discussed ${ }^{29}$.

Finds of long polished axes made of jade (jadeite) point in the same direction as they are not found as lost objects or settlement waste, but mostly as hoards ${ }^{30}$. The raw material came from extraction sites in the Alps between 1.500 and $2.400 \mathrm{~m}$ above sea level, at Monte Viso $70 \mathrm{~km}$ south-west of Torino and Monte Beigua north of Genova $^{31}$. The difficult access to the raw material, the time consuming production of the tools, and the kind of deposition in hoards, as well as the rareness of these objects allows an interpretation as signs of a conceptual value

24 Lüning 1967/1968; Höhn 2002.

25 Contributions in Badisches Landesmuseum Karlsruhe 2010; Knoche 2008, 125f., 143, 201; more references there.

26 Ramminger 2010.

27 E.g. de Grooth 1991; 2010; Kieselbach 2010; Lichardus 1998, 268; Louwe Kooijmans 2005; more references there.

28 Kieselbach 1998; Vanmontfoort 2004; see also Seifert 2012, 90 for the site of Zizers with Hinkelstein-Keramik in the Alpine Rhine valley, and Manen et al. 2004, 330 for the épicardiale Taï cave in the Gard valley near Avignon.

29 Roth 2000, 286 f.

30 E.g. recently discussed in Knoche 2013a.

31 Pétrequin et al. 2010; 2012. 
within the ritual beliefs and practices of the Michelsberg society.

Digging in the mountains was restricted to the warm period, and it has been calculated the elaborate production perhaps did not exceed a dozen axes annually ${ }^{32}$. At any rate, as these axes obviously were not used for profane work, they could have been (masculine?) symbols, immediately recognisable by everyone and distributed by inter-elite exchange ${ }^{33}$. Maybe such tools indicate a certain ranking within Michelsberg society.

This phenomenon - like the other lithic finds mentioned above - implies long-distance transfer and supraregional trade networks, which are also indicated by local stylistic adaptations and by finds (Kontaktfunde) of imported Michelsberg ceramics, e.g. ceramics from the Hegau region (Baden-Württemberg) at Hornstaad, ThayngenWeier and Wangen-Hinterhorn/Lake Constance, as mineralogical analysis has shown ${ }^{34}$. A comparable phenomenon are the Michelsberg finds in the sandy regions of the southern Netherlands ${ }^{35}$, in Belgium ${ }^{36}$ and in Switzerland ${ }^{37}$.

There were also routes for import from the south to the north as evidenced for example by - apart from the jadeite tools - pieces of antler tools (Hirschgeweih-Zwischenfutter), which are found all across the Alpine lakeshore sites but just as single finds in the Michelsberg earthworks, e.g. in Zornheim/Mayence (Rhineland-Palatinate) and in Heilbronn-Klingenberg (Baden-Württemberg) ${ }^{38}$, indicating knowledge, but no fundamental adoption of this technical possibility. In contrast to the cultures of Southern Europe and the Alpine foreland, copper finds are almost lacking at Michelsberg sites $^{39}$, demonstrating again the existence of "cultural borders" of exchange in terms of certain objects and practices.

\section{Material and methods}

Archaeobotanical data from 31 Michelsberg investigated sites in France, Belgium, southern Netherlands and Germany are available (Fig. 2, Tab.1-2). More than 800

32 Pétrequin et al. 2010; 2012.

33 Pétrequin et al. 2012, $1431 \mathrm{ff}$.

34 Knoche 2013b, 284, 287/foodnote 96; Lüning 1998, 281-285, Lüning 2000, 16 ff.; Matuschick 2011, 312; Schlichtherle 1998, 173; more references there.

35 Louwe Kooijmans 2005, 258.

36 Vanmontfoort 2004.

37 Doppler/Ebersbach 2011, 209.

38 Kieselbach 2010, 209; Schlichtherle 1998, 173 and pers. comm. 2013.

39 Pétrequin et al. 2010; 2012. samples from 228 archaeological features ${ }^{40}$ have been investigated and about 36000 plant remains from 113 plant taxa determined (Tab.4). In Tab. 2 the 27 archaeobotanical sites included in the calculations are listed ${ }^{41}$. All data were archived and circulated among the authors with the archaeobotanical database program of the Landesamt für Denkmalpflege Hessen/Wiesbaden ArboDat 2013.

The results from Bazoches (Yvelines), Cuiry-lèsChaudardes (Aisne), Heerlen-Schelsberg (Limbourg) and Maastricht-Klinkers (Limbourg) could not be included in the calculations as the data are too few or not fully avail$a_{b l e}{ }^{42}$. There are archaeobotanical data from two further Michelsberg sites (Schorisse "Bosstraat" (Oost-Vlanderen) and Enines "Chêne au Raux" (Orp-Jauche, Brabant) which were not available, as they have not yet been published by the archaeologists responsible ${ }^{43}$. In addition, mixing of material from different periods may occur, especially within the ditches of earthworks. Therefore we had to exclude the data from Heilbronn-Klingenberg, where the plant remains are partly mixed with material from the earlier Bandkeramik settlement. This was indicated by several ${ }^{14} \mathrm{C}$-dates and by Bandkeramik sherds regularly found within the ditches, but which unfortunately came to light after Stika had finished his work on the numerous plant-remain ${ }^{44}$.

Clearly, the state of research is not satisfactory, particularly with regard to the unequal numbers of features and samples per Michelsberg phase (Tab. 2). In most cases the areas excavated were small and therefore comprise just a small number of features or samples as shown by Fig. 3 and 4. Therefore, the chance of finding plant remains and a representative number of taxa is further limited, and the available data may not be representative for the site as a whole.

Concentration values have been calculated for features with an available sample volume ${ }^{45}$. The density of charred seeds/fruits and/or chaff is rather low at Michelsberg sites, as expected under dry mineral soil conditions: less than one to 36 charred remains per litre per site, or 5,9 per litre from 149 pits and similar features. Even lower values $(1,7 / 1)$ are calculated from the 154 samples from the Michelsberg banks and the ditches. More than 10 charred

40 Features sampled are mostly ditches, ramparts, pits and postholes (Tab.1). Former ground levels are not preserved, apart from the bases of the ramparts. Due to the dry mineral soil conditions just charred material is available.

41 Bruchsal-Aue BRA has three archaeological phases but is counted as one site here.

42 Bakels 1984; 1999, 74; 2003; Schreurs 1992, 140.

43 Corrie Bakels, Leiden, written comm. 12.4. 2013.

44 Seidel 2008, catalogue; Stika 1996 a and b.

45 Sample volumes are lacking at three sites. 


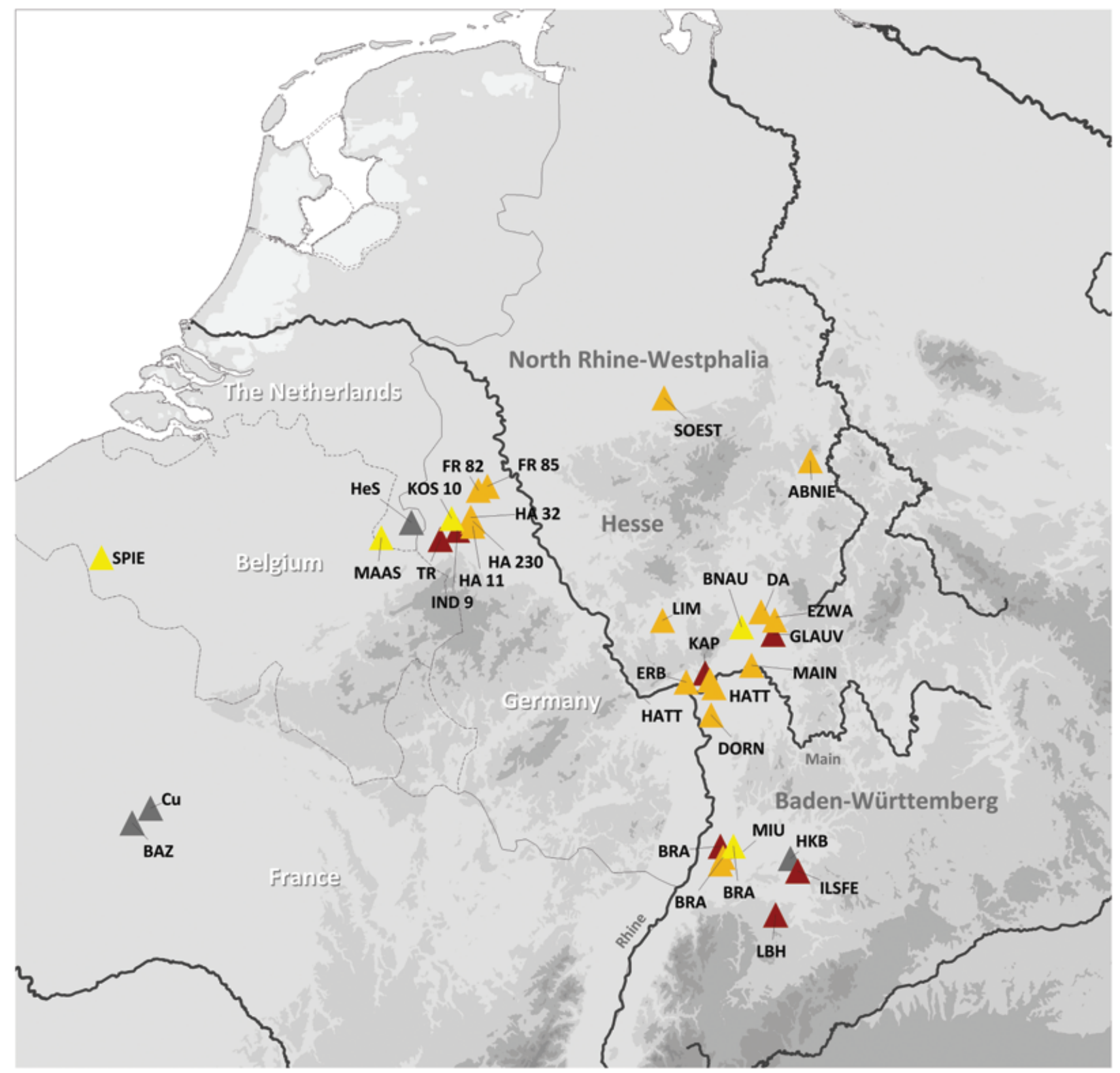

Earlier MK

\section{Younger MK}

\section{MK undiff.}

\section{A site not included}

Fig. 2: Distribution map of the Michelsberg sites with archaeobotanical investigations. Calculations and statistics are based on sites, which are marked in yellow, orange or red according to their archaeological dating. Sites marked in grey are only mentioned in the text. Abbreviations: ABNIE Altenburg, Niedenstein; BAZ Bazoches, Aisne; BNAU Bad Nauheim; BRA Bruchsal, Aue; CU Cuiry-lès-Chaudardes; DA Dauernheim, Ranstadt; DORN Dornheim, Groß-Gerau; ERB Erbenheim, Wiesbaden; EZWA Echzell „Wannkopf“; FR 82 Jüchen-Garzweiler, Elfgen; FR 85 Jüchen-Garzweiler, Belmen; GLAUV Glauberg-Vorwall; HA 230, HA 11 and HA 32: Hambach, Niederzier; HATT Hattersheim; HeS Heerlen-Schelsberg; HKB Heilbronn-Klingenberg; ILSFE Ilsfeld, Ebene; IND 9 Inden Geuenich; KAP Kapellenberg, Hofheim; KOS 10 Koslar; LBH Leonberg-Höfingen; LIM Limburg, Greifenberg; MAAS Maastricht-Vogelzang; MAIN Maintal-Hochstadt; MIU Michaelsberg/ Untergrombach; SOEST Soest Altstadt; SPIE Spiere de Hel; TR Tank \& Rast Aachen 
remains per litre (calculated average) occur at no more than $33 \%$ of the sites. Mass finds ("Vorratsfunde"), as defined by more than 100 pieces of crop seed remains per litre, have been found at three Michelsberg sites only: Jüchen-Garzweiler "Elfgen" and "Belmen" (naked wheat T. aestivum s.l./durum/turgidum and emmer T. dicoccum) and Ilsfeld "Ebene" (barley Hordeum distichon/vulgare).

As the archaeological excavations often have been constrained to the ramparts and the ditches of the enclosures, the question arose as to whether plant assemblages from Michelsberg refuse pits differ qualitatively from those from ditches and banks, especially with respect to the representation of the crop species. In order to answer this question a canonical correspondence analysis based on the number of taxa per Ecological Group per feature was conducted (Fig. 5-6) ${ }^{46}$. As expected there is a clear relationship between the volume investigated and the number of wild taxa found. On the other hand, it is important for the following argumentation that crop taxa (Ecological Group "crops" marked in yellow) are reasonably well represented (Fig. 5), as they occur in more than $65 \%$ of the features investigated.

Fig. 6 shows the same canonical correspondence analysis. Again, every symbol marks one feature, now with the pits and the ramparts or ditches indicated as feature types. It is evident that there is no qualitative separation of the two feature groups. Therefore both can be used equally well for the calculations. In addition, for a better control of the results calculated, in the following in some cases the Michelsberg data are compared with data from 151 further prehistoric sites of the Hessian data base ArboDat (Tab. 3).

\section{The Michelsberg crops}

The Michelsberg farmers grew four cereals: emmer Triticum dicoccum and einkorn T. monococcum, as well as naked wheat, apparently the tetraploid form T. durum/turgidum (see chapter below), and barley Hordeum distichon/ vulgare (Fig. 7). Interestingly there is no sure evidence for the cultivation of oil- or fibre-plants by the Michelsberg farmers until now ${ }^{47}$. This is surprising, as in the agricul-

46 As for the definition of the Ecological Groups and their critical use see Kreuz (2004/2005, 122 Tab. 8 and 147 ff.).

47 There are just two single charred finds of "cf. Linum usitatissimum" at the site Bruchsal-Aue BRA in one sample of the ditch system, and another in a grave (determined by Manfred Rösch). As for the latter, it is an inhumation burial so that the charred material must come from other contexts. According to Birgit Regner-Kamlah, LDA tural system of the southern contemporaneous neighbours of Michelsberg poppy Papaver somniferum and flax Linum usitatissimum clearly played a major role ${ }^{48}$.

To counter the objection that the lack of oil plants is only due to their bad preservation as charred material ${ }^{49}$, Tab. 3 shows the Hessian diachronic evidence for oil and fibre plants from 151 sites for other prehistoric periods. It is evident that even under the (from experience) bad preservation conditions of Bandkeramik sites, charred flax or poppy remains are present in the samples if these crop plants were in use $\mathrm{e}^{50}$. Therefore the lack of oil plants within Michelsberg features could be of significance, although the state of research still needs improvement.

There is rather scarce evidence in the Michelsberg area for pea Pisum sativum and lentil Lens culinaris. Here again, a diachronic comparison of the frequencies per site reveals that pulses were indeed rare at Michelsberg sites compared for example with their occurrence at Bandkeramik sites (Tab. 3).

\section{Origin of the tetraploid naked wheat?}

As already noticed by C.C. Bakels ${ }^{51}$, the Late Neolithic occurrence of tetraploid naked wheat is a break with the Middle Neolithic Rössen tradition of hexaploid naked wheat. The latter appeared in the investigation area at the end of the Bandkeramik culture ${ }^{52}$. Tetraploid naked

Baden-Württemberg (written comm. 13. 5. 2013), there are secondary dislocations of Bandkeramik sherds, especially in the Michelsberg ditches. Therefore it is quite possible that Bandkeramik flax seeds went into the filling of Michelsberg features too. ${ }^{14} \mathrm{C}$-datings of the seeds are needed to clarify the situation.

In addition there is the unusual find of 267 charred poppy seeds Papaver somniferum at Cuiry-lès-Chaudardes. As described by the author, they were partly indistinguishable from Papaver rhoeas (Bakels 1984, 4). In later publications they are just referred to as Papaver somniferum (Bakels 1991, Tab.3/284; Bakels 1999). Most features of this site are again of Bandkeramik origin. Therefore an intrusion of Bandkeramik material into the Michelsberg pit cannot be ruled out. ${ }^{14} \mathrm{C}$-datings of the seeds are needed here as well.

48 E.g. Jacomet 2007; Maier/Vogt 2001; Maier 2004; further references there.

49 E.g. Märkle/Rösch 2003.

50 The lack of opium poppy during the Earliest Bandkeramik is due to western Mediterranean influences not starting before the Flomborn period (LBK II; Bakels 1982; Kreuz 2010/2012). For the representation of crop species within the Michelsberg features see above and Fig. 5-6.

51 Bakels 2003, 23; see also Bakels 1990; 1994.

52 Kreuz 2010/2012, 141; Maier 1998. 


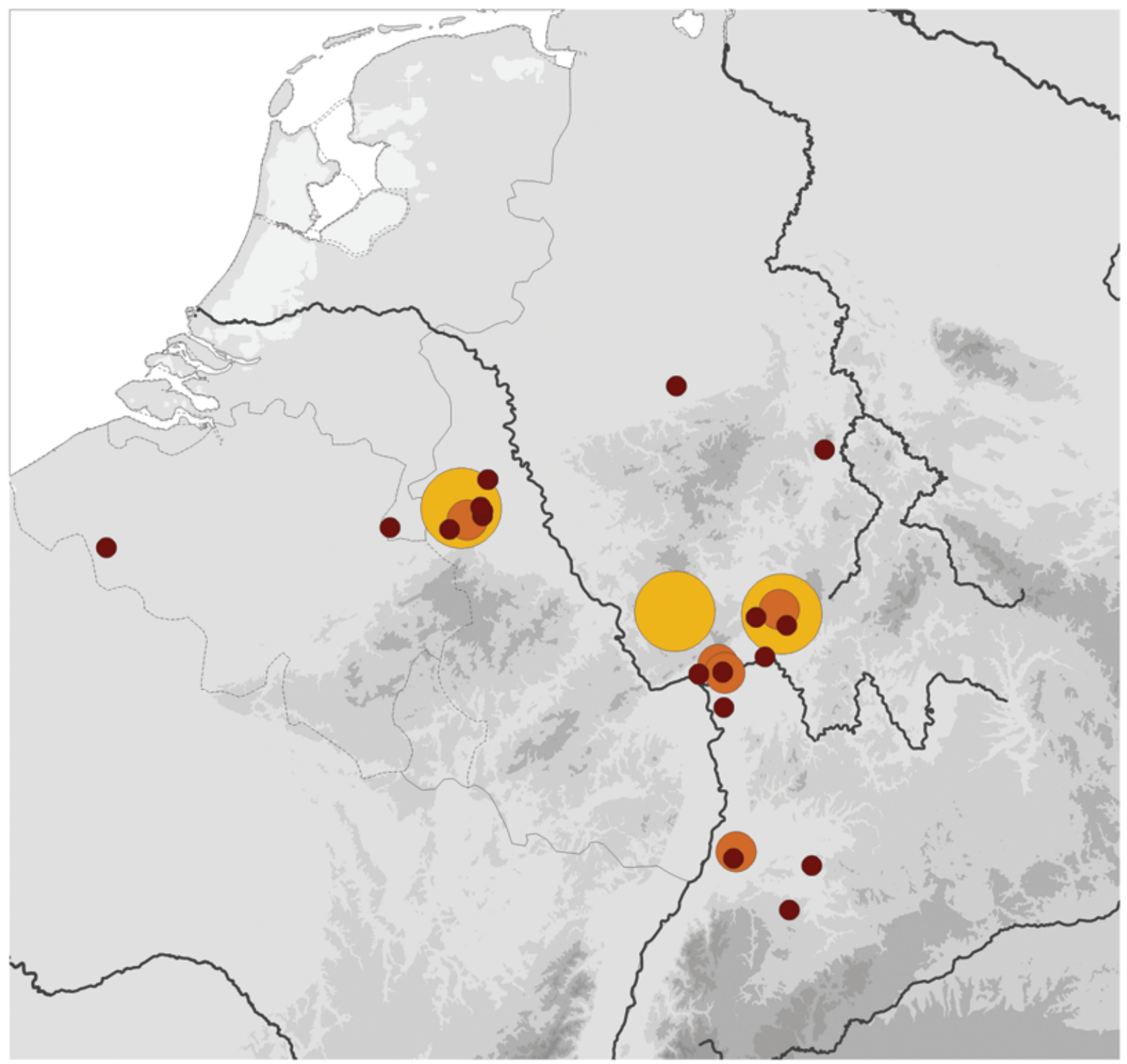

- < 10 features

10 - 20 features

\section{$>20$ features}

Fig. 3: Number of features investigated archaeobotanically mapped per Michelsberg site (see Fig. 4) 


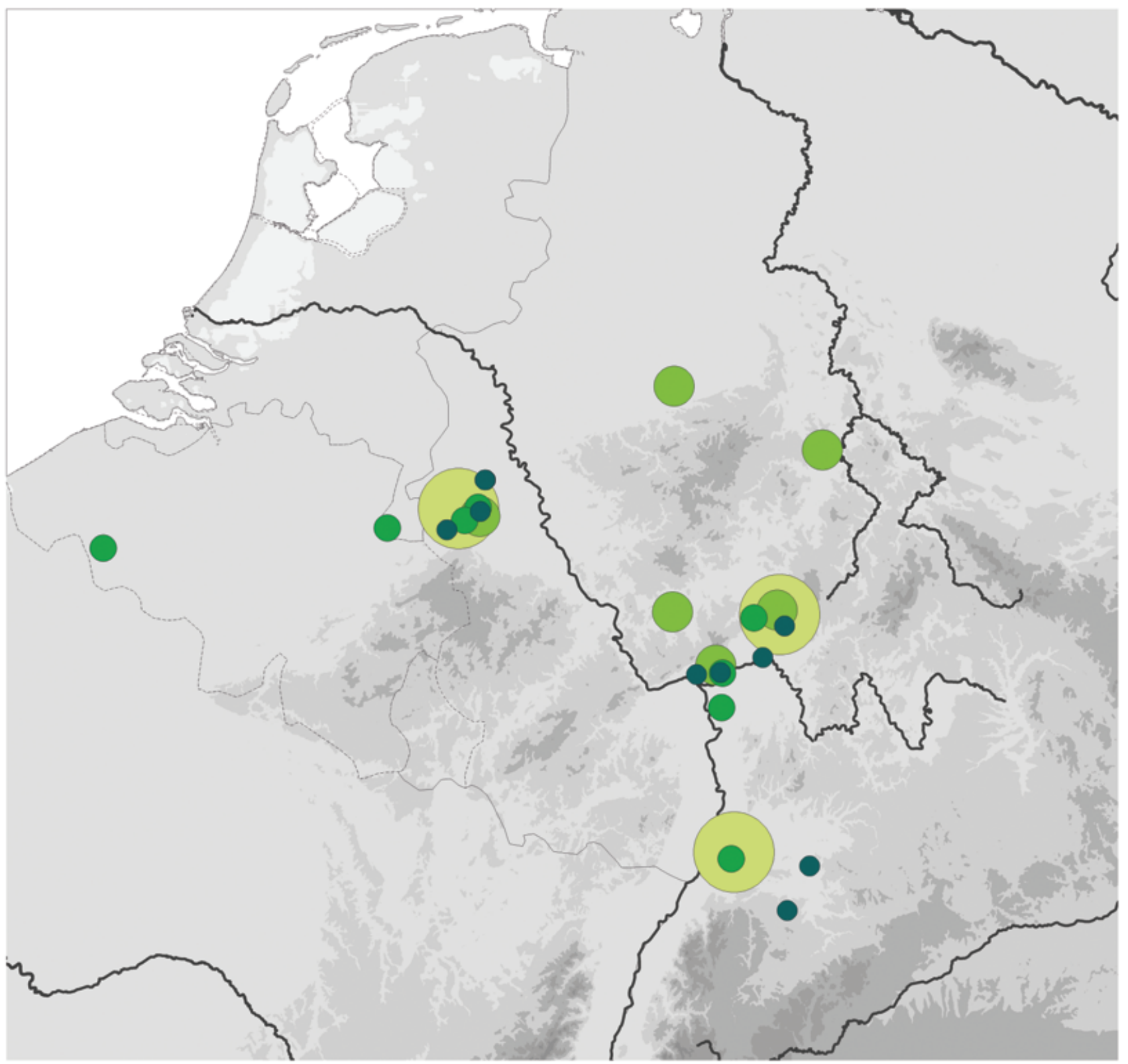

< 10 samples

\section{0 - 20 samples}

21 - 50 samples

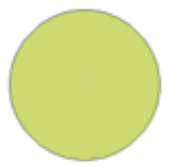

\section{$>\mathbf{5 0}$ samples}

Fig. 4: Number of samples investigated archaeobotanically mapped per Michelsberg site (see Fig. 3). The state of archaeobotanical research for the Michelsberg culture is supraregionally unequal and therefore in need of improvement 

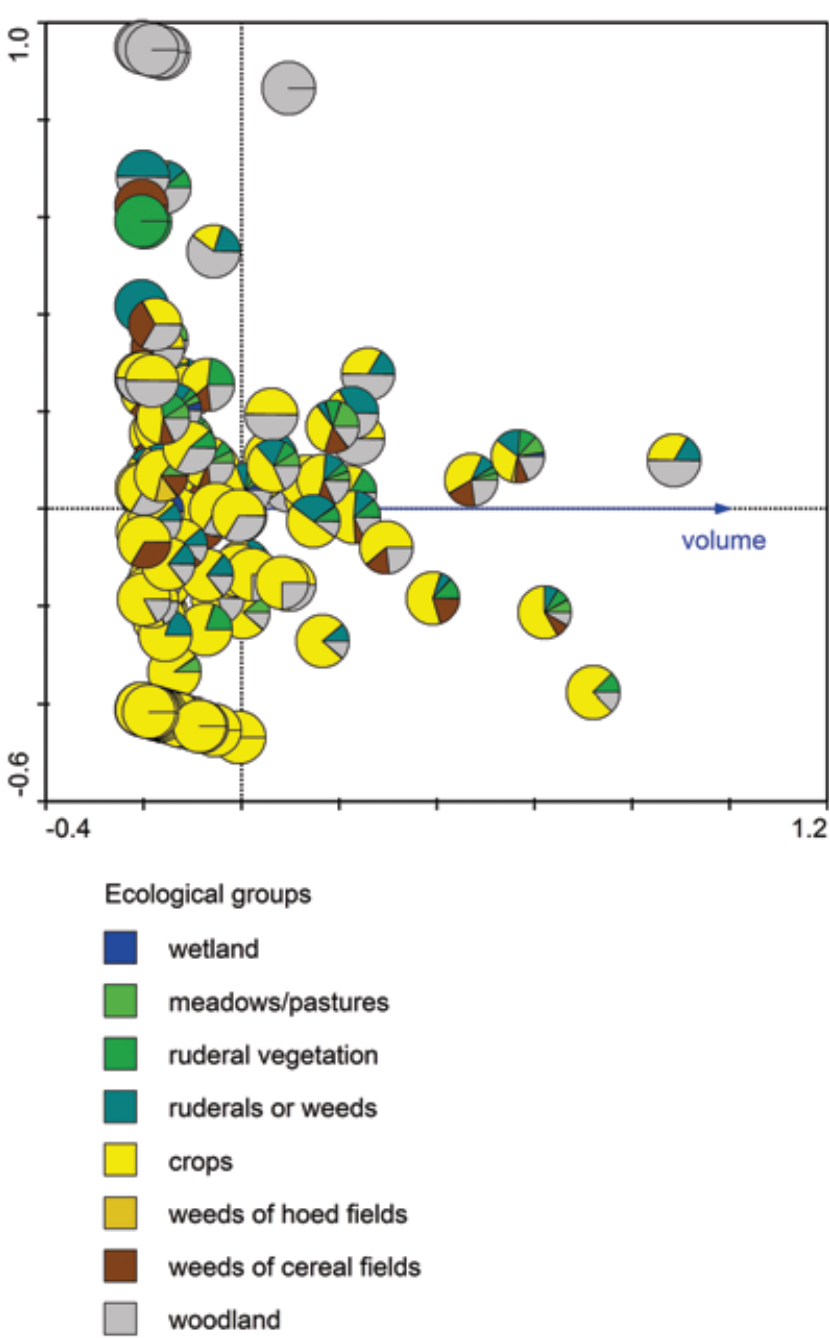

Fig. 5: Canonical correspondence analysis of features and the number of taxa per ecological group, constrained by the sample volume on the first axis. The pie charts represent the percentages of the numbers of taxa per ecological group per feature. Features with no sample volume available have been excluded. Marked in yellow are the crops, in orange and brown the "real weeds", in blue and green the other wild plants (see also Fig. 6)

wheat - the T. durum/turgidum form - has been identified by finds of rachis fragments at the two early Michelsberg sites Maastricht-Vogelzang/The Netherlands and Spiere/ Belgium (MK I/II), as well as in younger Michelsberg features from Heilbronn-Klingenberg, Baden-Württemberg/ Germany $^{53}$. The question remains, where the Michelsberg farmers adopted their tetraploid naked wheat from.

53 Bakels 2008; Bakels in Vanmontfort et al. 2001/2002; see also Bakels 2007, Tab.19.1; Stika 1996a and b; Vanmontfort 2004, 52; for the rachis fragments see Fig. 7; the other Michelsberg sites produced evidence for grains of naked wheat only, which cannot be differentiated further.

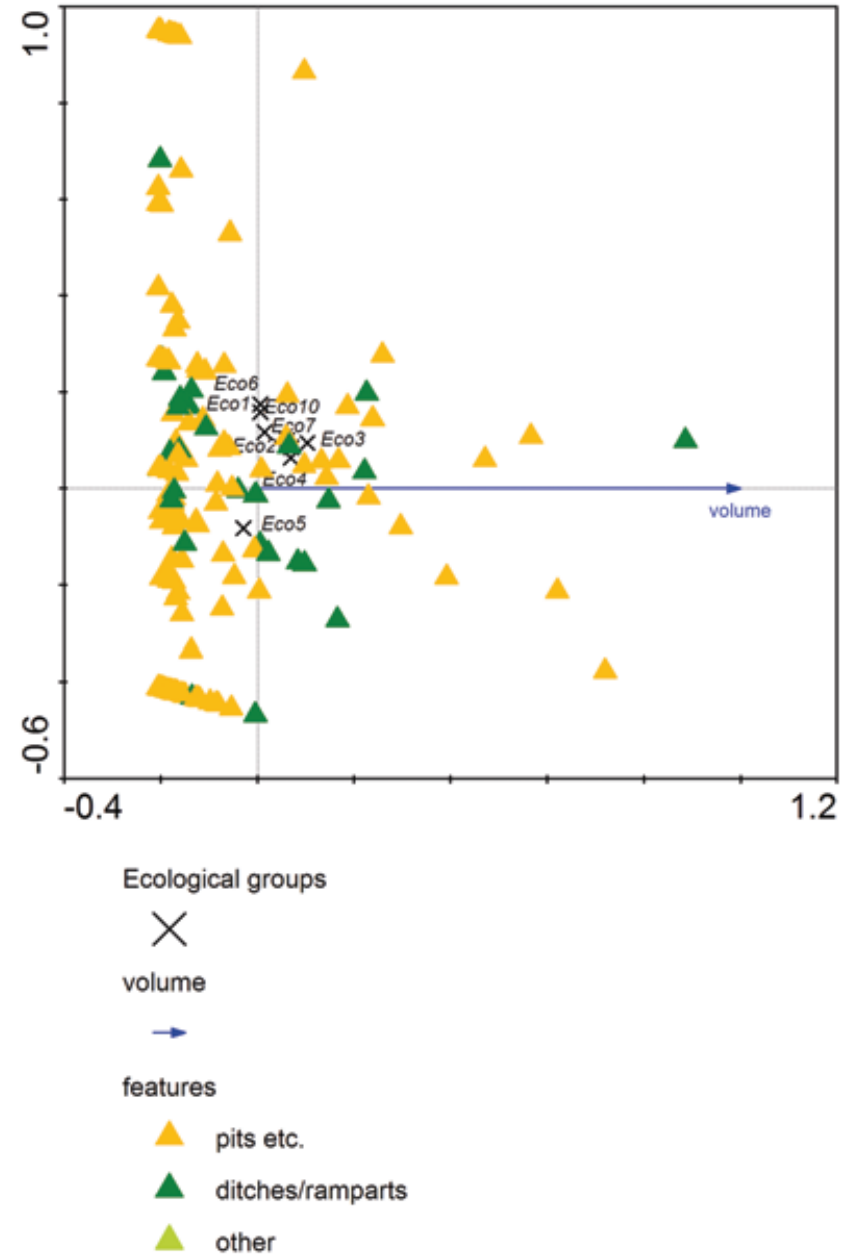

Fig. 6: Canonical correspondence analysis of features and taxa per ecological group, constrained by the sample volume on the first axis (see also Fig. 5). Here, features are classified according to the feature types pits (in the broadest sense), ditches/ramparts and other features. It is evident that there is no data separation related to the different feature types

Tetraploid naked wheat also is found in the early lakeshore sites of the northern Alpine foreland ${ }^{54}$, and it has been discussed as an introduction from the South-West ${ }^{55}$. The earliest three of these lakeshore/island sites, Zürich "Kleiner Hafner" (layers 5A, B and 4A-C/D), Egolzwil 3 und Cham-Eslen - belonging to the Egolzwil culture - do not date earlier, but are probably contemporaneous with early Michelsberg. The two earliest layers of "Kleiner Hafner"

54 E.g. Jacomet 2007; Martinoli/Jacomet 2002; Jacomet/Schlichtherle 1983; Maier 1996, 1999, 1998; see also Bakels 2003, 231. 55 E.g. Jacomet 2007, 246; Maier 1998. 

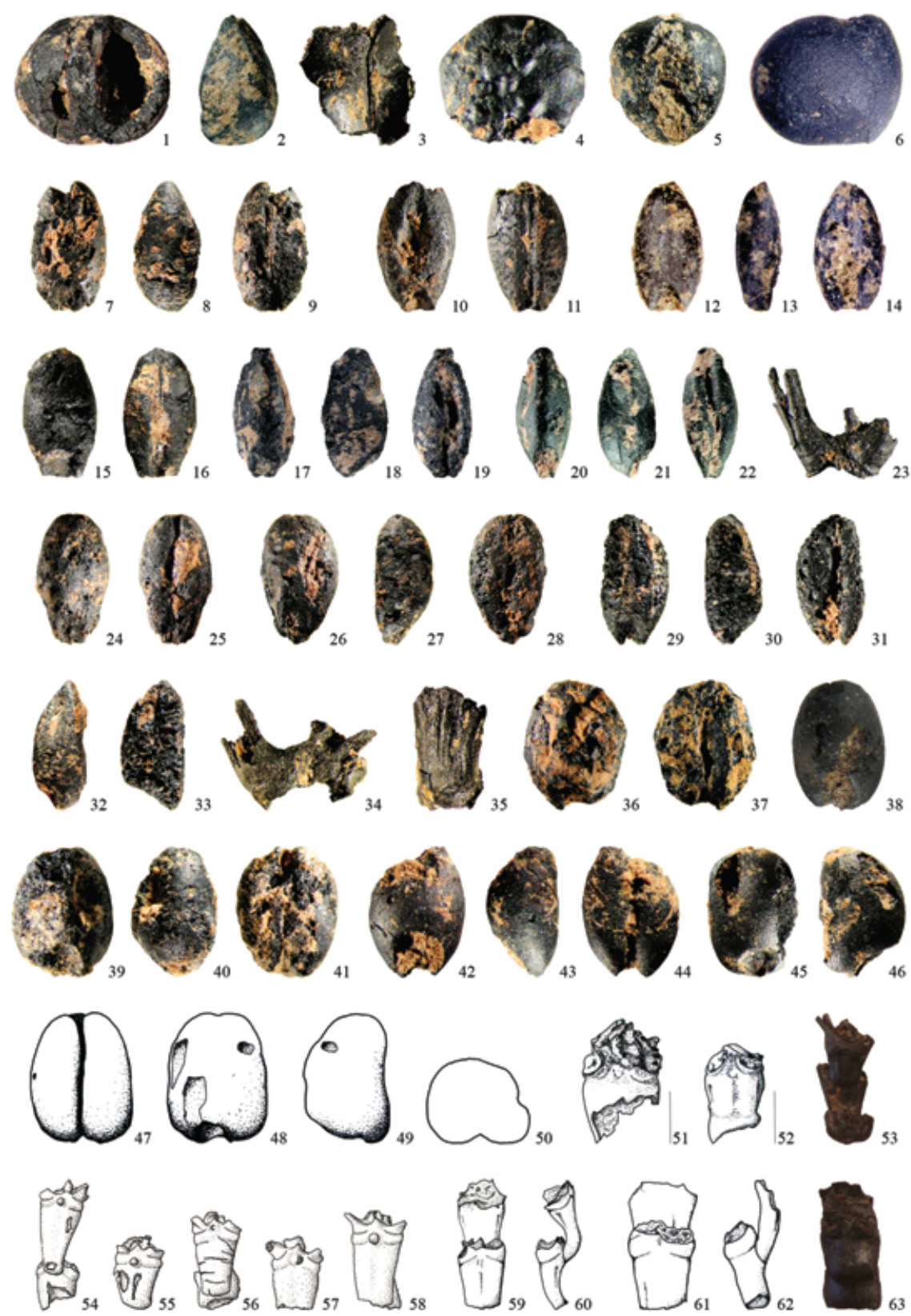

Fig. 7: Charred plant remains from several Michelsberg sites (L length in mm; for the location of the sites see Fig. 2): 1 Cornus sanguinea, pit (L 4,0), AK42 DA 1995, Pr. 90-2B; 2-3 Malus cf. sylvestris: 2 seed (L 6,75), AK 42 DA 1995, Pr. 1-3B; 3 fragment of pericarp (L 4,9), AK 42 DA 1995, Pr. 75-3B; 4 cf. Lens culinaris, seed (L 2,5), AK 320 HATT, Pr. 15; 5-6 Pisum sativum: seeds 5 (L 3,6), AK 42 DA 1995, Pr. 45-6EF; 6 (L 3,6), AK 8 SU 1, Pr. 110; 7-16 Hordeum distichon/vulgare: 7-9 grain: dorsal, lateral, ventral (L 5,7), AK 331 MAIN, Pr. 301-32; 10-11 grain: dorsal, ventral (L 4,05), AK 4 Echzell, Pr. 69-7; 12-14 grain: dorsal, lateral, ventral (L 5,2), AK 42 DA, Pr. 72-128; 15-16 grain: dorsal, ventral (L 4,3), AK 331 MAIN, Pr. 301-32; 17-23 Triticum monococcum: 17-19 grain: dorsal, lateral, ventral (L 4,8), AK 42 DA 1995, Pr. 65-3B; 20-22 grain: dorsal, lateral, ventral (L 5,5), AK 42 DA 1995, Pr. 30-2B; 23 spikelet fork (L 2,1), AK 42 DA 1995, Pr. 34-5B; 24-35 Triticum dicoccum: 24-25 grain dorsal, ventral (L 5,8), AK 42 DA 1995, Pr. 1-2A; 26-28 grain: dorsal, lateral, ventral (L 5,9), AK 331 MAIN, Pr. 301-32; 29-31 grain: dorsal, lateral, ventral (L 4,95), AK 331 MAIN, Pr. 304-25; 32 grain: lateral (L 3,5), AK 276 BN-Sie, Pr. 213; 33 grain: lateral (L 5,65), AK 331 MAIN, Pr. 304-25; 34 spikelet fork (L 1,8), AK 42 DA 1995, Pr. 34-5B; 35 glume base (L 2,0), AK 42 DA 1995, Pr. 45-6EF; 36-37 Triticum aestivum s.l./durum/turgidum, grain: dorsal, ventral (L 4,55), AK 42 DA 1995, Pr. 72-2B; 38 Triticum durum/turgidum, grain: dorsal, determined by rachis segments, material from Spiere (prov. West-Vlaandern/Belgium); 39-50 Triticum aestivum s.l./durum/turgidum: 39-41 grain: dorsal, lateral, ventral (L 4,0), AK 281 KAP 2008, Pr. 8; 42-44 grain: dorsal, lateral, ventral (L 3,2), AK 276 BN-Sie 2008, Pr. 213; 45-46 grain: dorsal, lateral (L 3,3), AK 276 BN-Sie, Pr. 213; 47-50 grain FR 2001 (Zerl 2003, Fig. 17); 51-52 Triticum aestivum s.l., rachis segments; 53-63 Triticum durum/turgidum rachis segments: 53-58, 63, Heilbronn Klingenberg; 59-62 FR 2001 (Zerl 2003, Fig. 19-20). (pictures: 1-5, 7-11, 15-37, 39-46 S. Gehner, HessenArchäologie; 6, 12-14 H. v. Schlieben, HessenArchäologie; 38 C. C. Bakels unpubl.; 47-50 (Fig. 17), 51-52 (Figs. 22-23), 59-62 (Figs. 19-20) Zerl (2003); 53, 63 Manfred Rösch/Tanja Märkle unpubl. (3631-3639); 54-58 Stika (1996, Fig. 25 detail) 
in Zürich are dated by E. Gross ${ }^{56}$ between 4375 and 4250 cal BC, corresponding approximately with Michelsberg phase $\mathrm{II}^{57}$.

Tetraploid naked wheat also comes from the subsequent Early Cortaillod sites of Central Switzerland (corresponding to phase MK II too), as well as at Lake Constance at Hornstaad-Hörnle IA (corresponding to MK II/ $\mathrm{III}^{58}$ ), and at the sites of the Pfyn/Altheim group of southern Bavaria $^{59}$, which is parallel to later Michelsberg (after 3.900 cal BC; MK III ff.).

The Rössen culture marks the end of the Middle Neolithic in the loess landscapes of the investigation area, where in between Rössen and Michelsberg the transitional Bischheim culture occurs (Fig. 1) ${ }^{60}$. Both Bischheim and Michelsberg ceramics were influenced stylistically by the western Chasséen traditions ${ }^{61}$. Notably, tetraploid naked wheat is already present in sites of the Bischheim culture $^{62}$.

In contrast to the Michelsberg farmers, those from the Bischheim group cultivated a more diverse crop spectrum with opium poppy Papaver somniferum and flax Linum usitatissimum, as well as naked barley Hordeum distichon/ vulgare, hexaploid and tetraploid naked wheat Triticum aestivum s.l. and Triticum durum/turgidum, glume wheats Triticum dicoccum and monococcum, lentil Lens culinaris and pea Pisum sativum as additional crops ${ }^{63}$. As Bischheim is earlier than Egolzwil and Michelsberg, Bischheim and/ or its cultural roots could have been a catalyser for the agricultural adoption by the Egolzwil lakeshore settlers of the northern Alpine foreland, where tetraploid naked wheat and oil plants have been found regularly from the second half of the $5^{\text {th }}$ millenium cal BC onwards. Actually,

56 Eda Gross, Amt für Denkmalpflege und Archäologie Zug, written comm. 31. 5. 13.

57 Following Höhn 2002.

58 Following Matuschik 2011.

59 Jacomet 2007, 244 f.; Rösch 2013; more references there.

60 E.g. Herrmann/Jockenhövel 1990, 151 ff.; Jeunesse 1998; Lüning 1981; Schier 1993; critical e.g. Raetzel-Fabian 2006, 181.

61 E.g. Gross-Klee 1998; Jeunesse et al. 2004, maps in Fig. $186 \mathrm{ff}$;; Knoche 2008, 123 ff.; Vanmontfort 2004.

62 Evidence comes from Schernau (Hopf 1981), Creglingen-Frauental (Rösch 2014) and Oberderdingen-Großvillars “Seeberg” (M. Rösch unpublished data) and from two sites near Jüchen-Garzweiler/Lower Rhine valley (Frimmersdorf 2001/103 and Frimmersdorf 137; Zerl 2003; see also Arora/Zerl 2004; Päffgen/Zerl 2005). In addition there is a find of three rachis remains from the probably "late Rössen" site Oespeler Bach, feature 202. There is a ${ }^{14} \mathrm{C}$-date from the same feature (KN-4573, 4488-4374 cal BC [1б], which might be contemporaneous with Bischheim (Brink-Kloke/Meurers-Balke 2003, Tab. 1, determinations by Rainer Pasternak).

63 Becker 1991; Hopf 1981; Rösch 2014; M. Rösch unpubl.; Zerl 2003, 62.
Egolzwil pottery shows similarities to those of Bischheim, but also direct contacts to the (South-) West ${ }^{64}$. This leads to the question of the formation of farming settlements in the first half of the $5^{\text {th }}$ millennium cal BC in the Alpine region of Switzerland and France.

Unfortunately, in France and Switzerland the state of archaeological research for the period prior to the lakeshore settlements is rather vague and archaeobotanical investigations are rare until now, although promising new investigations have just started ${ }^{65}$. Some sites on mineral soil with archaeological traces of contact to the North and/or South-West during the $5^{\text {th }}$ millennium cal BC will be considered here.

The earliest of these sites with archaeobotanical investigations is situated in the Alpine Rhine valley at ZizersFriedau near Chur (GR, Switzerland), and dates to the first half of the $5^{\text {th }}$ millennium cal BC. In addition there is the find of some sherds of a small Rössen vessel $(15 \mathrm{~cm}$ height, $17 \mathrm{~cm}$ diameter) from the castle of Gutenberg-Balzers (Liechtenstein) nearby in the Rhine valley, $50 \mathrm{~km}$ from Lake Constance and of unclear taphonomic origin ${ }^{66}$.

The site Zizers-Friedau is situated on the dry mineral soil of an alluvial fan ("Rüfenfächer") at the border of the Rhine terrace. It produced a culture layer, on average $10 \mathrm{~cm}$ thick, with two activity zones comprising hearth pits with heating stones and lithic finds, as well as 15 round-bottomed pottery vessels reminiscent of the Hinkelstein style, in part influenced stylistically from the area south of the $\mathrm{Alps}^{67}$. In this context the provenance of the lithic finds is of interest, coming from, among other areas, Bavaria ( $8 \%$ ) and Upper Italy $(11 \%)^{68}$.

Depressions in the ground of $4-25 \mathrm{~cm}$ diameters are no evidence for the structure of a building at Zizers. Unexplained are 36 small "hills" consisting of humic material with diameters of $20-60 \mathrm{~cm}$ protruding from the culturelayer ${ }^{69}$. The bone fragments, which perhaps were so small due to the soil conditions, could not be determined. Important finds are 2539 charred plant remains, including 365 barley grains Hordeum distichon/vulgare, 22 grains and 56 chaff-remains from emmer Triticum dicoccum, three grains and six chaff remains from einkorn Triticum monococcum as well as five grains of naked wheat Triticum aestivum s.l./durum/turgidum, 21 seeds of pea Pisum sativum

64 E.g. Denaire et al. 2011, 35 ff., Fig. $11 \mathrm{ff}$.; for the discussion of Neolithic cultural influences see e.g. Jeunesse/van Willigen 2010.

65 Stefanie Jacomet, Basel, personal comm. September 2013.

66 Commented critically by the author himself (von Merhart 1936, 29).

67 Seifert 2012.

68 Seifert 2012, Fig. 13.

69 Seifert 2012, $80 \mathrm{f}$. 
and one seed of opium poppy Papaver somniferum ${ }^{70}$. This crop spectrum fits well into the Middle Neolithic tradition from the loess landscapes more to the North (see above). Due to the lack of rachis fragments the naked wheat could not be differentiated further. ${ }^{14} \mathrm{C}$-dates obtained from hazelnut shells gave an age of around $5900 \mathrm{BP}^{71}$.

A further important site of the first half of the $5^{\text {th }}$ millenium cal BC that has been archaeobotanically investigated is situated at Sion in the Rhône valley east of Lake Geneva (lac de Genève) in the canton Valais (Wallis) ${ }^{72}$. The naked wheat at this site was again preserved as grains only. This important archaeobotanical material was recovered long ago by the late Karen Lundström-Baudais, and is now under examination by Lucie Martin, Université de Genève $^{73}$. The results have to be awaited from there.

Three further Neolithic sites situated in the region of the Alpine Rhine valley date to the second half of the $5^{\text {th }}$ millenium cal BC (Sevelen-Pfäfersbüel and Sevelen-Geissberg ("Epi-Rössen"74), and Schellenberg-Borscht" ${ }^{75}$ ("EpiRössen" until "Horgen") ${ }^{76}$.

Sevelen-Pfäfersbüel is a well-documented hill-top site bordering the Rhine valley east of Lake Zürich (4.3604.040 cal BC; contemporaneous with Early Michelsberg and Egolzwil), again with a culture layer, based here on the local loess sediment. The culture layer contained several fire-places with heating stones, a considerable amount of ceramics (type Borscht, Aichbühl and Lutzengüetle/Early Pfyn), as well as lithic artefacts with supraregional proveniences ${ }^{77}$. At this site the reconstruction of a house is not convincing, as there are no clear building structures and the distribution of the artefacts and several fireplaces in an excavated area of ca. $20 \mathrm{~m}^{2}$ does not really sustain the hypothesis ${ }^{78}$.

The bone artefacts and fragments identified belong to wild and domestic animals, with cattle dominating, followed by pig and in smaller quantities sheep/goat. This result is interpreted by R. Ebersbach as representing the

70 Brombacher/Vandorpe 2012.

71 Brombacher/Vandorpe 2012, 95.

72 Ebersbach et al. 2012, Fig. 6 and Tab. 2; According to Winiger 2009 (e.g. Fig. 14) further Neolithic sites in this region date to the second half of the 5th, or to the first half of the 4th millenium cal BC.

73 Personal comm. by Stefanie Jacomet/IPNA Basel, September 2013.

74 "Epi-Rössen" is characterized by so-called "Kugelbecher" of the Borscht-Izighofen type from the site Schellenberg-Borscht (Rigert et al. 2005, 42).

75 Seifert 2004.

76 Following the maps in Denaire et al. 2011 and Seifert 2012, Fig. 1; discussed also in Rigert et al. 2005.

77 Rigert et al. 2005, $52 \mathrm{ff}$.

78 Rigert et al. 2005, 46 and Fig. 6-7.
"Balkan tradition" of stock-breeding, in contrast to the dominance of sheep/goat at the sites from southern and western Switzerland ${ }^{79}$. Rigert et al. ${ }^{80}$ discuss the relationship of different cultural influences based on the typochronology of the ceramics, concluding the "Epi-Rössen" finds resemble more the Late Neolithic group of Aichbühl in south-western Germany than the contemporaneous Egolzwil culture of the Swiss Plateau ("Mittelland").

The archaeobotanical investigation of the two samples from Sevelen-Pfäfersbüel by Akeret revealed crop finds, with barley Hordeum distichon/vulgare, naked wheat Triticum aestivum s.l./durum/turgidum, emmer Triticum dicoccum and einkorn Triticum monococcum, as well as flax Linum usitatissimum and opium poppy Papaver somniferum. Due to the lack of rachis fragments, again the naked wheat could not be determined further. In this case a tetraploid form could be expected, as is known from the Egolzwil sites at the lakeshores ${ }^{81}$.

Further Neolithic sites on mineral soil have been partly excavated on the plateau de Bevaix, near the Lac de Neuchâtel. Two of these sites have been investigated archaeobotanically: Saint-Aubin (parcel: Derrière la Croix) and Bevaix (two neighbouring parcels: Les Maladiéres and Treytel-Á Sugiez) ${ }^{82}$.

The older features of Saint-Aubin and Bevaix represent a site type possibly not occupied permanently ${ }^{83}$. As for the "Néolithique moyen I" of Saint-Aubin/Derrière la Croix, again a culture layer with a maximum thickness of $15 \mathrm{~cm}$ has been excavated lined by a row of five menhirs, and with several fire-places and hearth-pits with cooking stones $^{84}$. Notably the proveniences of the lithic finds from this site point to the North-East, judging by imports from the region of Basel ${ }^{85}$. The site of Bevaix, with similar features to Saint-Aubin, is convincingly interpreted by the archaeologists in charge as a site for ritual, sacred functions ${ }^{86}$.

At Saint-Aubin, apart from barley Hordeum distichon/ vulgare, emmer and einkorn Triticum dicoccum and monococcum, pea Pisum sativum and one seed of flax Linum

79 Ebersbach in Rigert et al. 2005, 60.

80 Rigert et al. 2005, $60 \mathrm{ff}$.

81 Akeret in Rigert et al. 2005, 57 f.; Jacomet 2007.

82 Akeret/Geith-Chauvière 2003; Akeret/Geith-Chauvière 2011a, see 29 ff. and Fig. 13; Akeret/Geith-Chauvière 2011b; Grau Bitterli/FierzDayer 2011; Wüthrich 2003.

83 Akeret/Geith-Chauvière 2003, 292; Grau Bitterli/Fierz-Dayer 2011, e.g. $345 \mathrm{ff}$.

84 Wüthrich 2003, e.g. Fig. 87.

85 Wüthrich 2003, Fig. 109.

86 Grau Bitterli/Fierz-Dayer 2011, e.g. $345 \mathrm{ff}$; see also the inpressive pictures of the menhirs and surrounding features $\mathrm{p} .95 \mathrm{ff}$. 
usitatissimum, as well as tetraploid naked wheat Triticum durum/turgidum have been identified within four structures. At Bevaix oil plants are lacking, but instead pea Pisum sativum was identified. Tetraploid naked wheat has also been found at Bevaix/Les Maladières, within somewhat younger features archaeologically dated to Cortaillod Ancien ${ }^{87}$.

The excavation at Saint-Aubin gave ${ }^{14} \mathrm{C}$-dates in the range of $4.800-4040^{88}$. Unfortunately just two of these dates from features St-39 and St-28, which did not contain remains of tetraploid naked wheat, belong to the first half of the $5^{\text {th }}$ millenium cal $\mathrm{BC}$, while seven to eight dates are later, clearly belonging to the second half of the $5^{\text {th }}$ millenium ${ }^{89}$. Therefore this site does not allow to date the introduction of tetraploid naked wheat into the Swiss Plateau.

To summarise, the earliest archaeological sites of the $5^{\text {th }}$ millenium cal BC in France and Switzerland compiled by Denaire et al. and Ebersbach et al. ${ }^{90}$ are either cave sites and abri (often published by the excavators without clear profile drawings or plans), which might have been hunting or (later) herdsmen camps ${ }^{91}$, or they comprise mineral soil sites consisting of "culture-layers" with fire places and hearth pits with cooking stones and sometimes menhirs (see above), which do not fit to the known Middle Neolithic tradition of, for example, Rössen settlement structures. On the contrary, hearth pits with charcoal, heating stones and flint remains are a common phenomenon at Mesolithic sites, for example in western Lower Saxony and in the northern Netherlands, as recently mapped by Fries et $a .^{92}$. In this context the widespread phenomenon of the stone bordered graves ("cistes de Chamblandes") ${ }^{93}$ in midwest France and Switzerland is remarkable, beginning in the first half of the $5^{\text {th }}$ millennium BC and never appearing combined with "real" settlement structures. This phenomenon is connected by Denaire et al. ${ }^{94}$ with the roundbottomed and - in contrast to the Chasséen - undecorated pottery of the Saint-Uze style (syn. Proto-Cortaillod, Chasséen ancien).

87 Akeret/Geith-Chauvière 2011a, 29 ff. and Fig. 13.

88 4810-4460, 4550-4250, 4500-4220, 4780-4400, 4460-4040 and 4770-4360 cal BC; Akeret/Geith-Chauvière 2003, 285; Wüthrich 2003, 104 f., Fig. 132 and Fig. 133.

89 Wüthrich 2003, 104 f., Fig. 132-133.

90 Denaire et al. 2011, Fig. 9; Ebersbach et al. 2012, Tab. 1-2; see also Manen et al. 2004.

91 See e.g. Chaffenet/Cordier (1999) as well as the discussion in Bréhard et al. (2010) for the Rhône valley.

92 Fries et al. 2013, e.g. Fig. 7.

93 Gallay 1977; contributions in Moinat/Chambon 2007.

94 Denaire et al. 2011, 38.
Possibly the phenomenon of the "Chamblandes", as well as the "fire place-sites" mentioned above, represent a transitional phase of a local (Late-Mesolithic?) population, influenced by the north and the south-west. This "substrate" may in the end have led to the farming system of the Swiss Egolzwil and subsequent lakeshore settlers that differed, for example, to that of the earlier settled loess landscapes in the North ${ }^{95}$.

During the $5^{\text {th }}$ millenium cal BC (and before), thanks to the archaeological finds there is no doubt about direct or indirect trans-Alpine exchanges and cultural influences: on the one hand with the culture of Bocca Quadrata, e.g. from the southern Alpine foreland through the Adige-/South Tyrol (Etsch-Tal) and the Rhône-valleys ${ }^{96}$, on the other hand via long distance contacts to the north, for example with the Middle-Neolithic Hinkelstein and Rössen contexts (see above).

Due to the present state of research, the diffusion of tetraploid naked wheat to the North cannot be traced at the moment. Different scenarios are possible: Jacomet, Maier and Schlichtherle ${ }^{97}$ discussed a possible origin of tetraploid naked wheat in the west-mediterranean Cardial culture. Definite finds with rachis remains are in fact known from La Draga in Catalonia/Spain, dating to the second half of the $6^{\text {th }}$ millenium cal $\mathrm{BC}^{98}$. Tetraploid naked wheat is expected to be found in southern France from the early Neolithic onwards. Unfortunately, the naked wheat finds from there have so far been just grains, which cannot be determined further ${ }^{99}$.

During the $5^{\text {th }}$ millenium cal BC tetraploid naked wheat may have been distributed as far as the Paris basin in northern France, and from there to the Bischheim and Michelsberg zone of Germany. Alternative routes might have run either along the Rhône/Saône and/or the Doubs/ Rhine valleys (Belfort Gap), or crossing the Alpine region

95 See also the "pre-Cortaillod" datings in Boisaubert et al. (2008, Annexe 2.2) and the interesting contextual discussion in Nicod/ Coutard (2009) of the "Grotte du Gardon", west of lake Geneva at the northern border of the Rhône valley, and by Thiériot and Saintot (1999) from the pit with "Saint-Uze" and "Bocca-Quadrata" material (2. half of 5th millenium cal BC) at Estournelles à Simandres south of Lyon/Rhône, which is interpreted as trans-Alpine "French/Italian" exchanges with the regions of Piedmont and Liguria; see also Winiger (2009, 268 ff.) for Saint-Léonard Sur-le Gran-Pré/Valais/Rhône and the typo-chronologial relationship with the Chasséen.

96 E.g. Denaire et al. 2011; Nicod/Coutard 2009, 520; Nisbet 2008; Rottoli/Castiglioni 2009; Thiériot/Saintot 1999.

97 Jacomet/Schlichtherle 1983; Jacomet 2007, 246; Maier 1996, 1998. 98 Ferran Antolín, written comm. 13. 8. 2013; Antolín/Buxó 2011; Bogdanovic/Piqué 2012, Tab. 1; Buxó 2007; Pena-Chocarro et al. 2005. 99 E.g. Bouby in Manen et al. 2004; Maier 1998, 213 and Tab 1; Marinval 1988, 2007. 
from the south-west, for example by the Rhône and Aare valleys and/or through the Alpine Rhine valley.

Egolzwil and the subsequent cultures of the Alpine lakeshore sites either introduced tetraploid naked wheat by direct contact from south-west France, or from the Bischheim zone in the North. In any case, the material culture of Bischheim and Michelsberg was apparently influenced by French cultural connections (Chasséen complex) ${ }^{100}$.

In this context it may be significant that the earliest Michelsberg sites seem to provide more evidence of naked wheat than the younger sites. Fig. 8 shows a comparison of the numbers of cereal grain finds mapped for 29 Michelsberg sites. Four sites with too few grains had to be excluded, therefore the database used is smaller. It is evident that there is a slight difference between the areas to the right and the left of the river Rhine, which might be related to the different archaeological dating of the sites (Tab.1). A bit more more naked wheat occurs in the earlier sites to the west, and more glume wheat at the younger sites (MK III ff.) in the east. A further hint in the same direction is given by a correspondence analysis based on the abundance of grain/seed numbers per site (Fig. 9). Again a certain tendency of separation is evident, indicated by the position of the earlier Michelsberg sites marked in yellow influenced by naked wheat ${ }^{101}$.

A better archaeobotanical data set is needed in the future for testing this hypothesis. In the following it will be discussed if all the developments of crop growing mentioned above were driven by cultural decisions or by ecological factors, for example climatic development?

\section{Climate as a trigger for agricultural developments?}

A progressive decline in summer temperature from the Middle Holocene is documented by pollen and plant macrofossil data in Northern and Central Europe ${ }^{102}$. The age of the Michelsberg culture coincides with periods considered to be characterized by rapid global climatic changes (RCC). The interval 6000-5000 cal BP (4050-3050 cal BC)

100 E.g. Gross 1990, 61 ff.; Jeunesse et al. 2004; see also the discussion of Michelsberg vessels with perforated ledges in the context of the French Neolithic (Knoche 2013b, e.g. 293).

101 The fact that the site of Bruchsal Aue is not in the "right" position among the earlier sites might be due to the fact that there is also a mixing of different MK phases (and Bandkeramik, Regner-Kamlah written comm. 13. 5. 2013) on site, therefore we cannot be completely sure of the archaeological dating of the samples from there.

102 Brewer et al. 2009; Davies et al. 2003. features North Atlantic icerafting events ${ }^{103}$, alpine glacier advances ${ }^{104}$ and stronger westerlies over the North Atlantic and Siberia ${ }^{105}$. A data set of radiocarbon, tree-ring and archaeological dates obtained from sediment sequences in 26 lakes in the Jura mountains, the northern French PreAlps and the Swiss Plateau was used by Magny ${ }^{106}$ as evidence of a rather unstable Holocene climate punctuated by phases of higher lake levels, including at the beginning and at the end of the Michelsberg culture: 4400-4310, 3700-3250 cal. BC/6350-5900, 5650-5200 cal. BP (Magny episodes 10 and 9, corresponding in part with the Piora or Rotmoos I and Piora or Rotmoos II oscillations ${ }^{107}$; Fig. 10). However, such global climatic events could have caused locally different effects. On the scale of western Central Europe they are not always clearly detectable ${ }^{108}$.

The evidence from the Eifel maar lakes provides an opportunity of tracing possibly climate induced environmental change ${ }^{109}$. Kühl and Moschen ${ }^{110}$ investigated pollen and oxygen isotopes of moss cellulose $\left(\delta^{18} \mathrm{O}_{\text {Spagnum }}\right)$ from the peat bog "Dürres Maar" in the Eifel (low mountain range, Germany, $450 \mathrm{~m}$ a.s.l.): "Around $6000 \mathrm{cal} \mathrm{BP}$ [4050 cal BC], the pollen-based reconstructions indicate mean July temperatures $\sim 1{ }^{\circ} \mathrm{C}$ decreased, which is confirmed also by $\delta^{18} \mathrm{O}_{\text {Sphagnum }}$ values pointing at decreasing continentality for this period ... After $\sim 5500$ cal BP [3550 cal BC] the pollen-based reconstructions indicate little variability in summer temperature, while, winter temperatures show several pronounced cold excursions (lowering of the mean January temperature with $\sim 2-4^{\circ} \mathrm{C}$ ) in this period, which was likely accompanied by changes in precipitation patterns indicated by the $\delta^{18} \mathrm{O}_{\text {Sphagnum }}$ values"111. The latter coincides with the end of the Michelsberg period.

The occurrence of Hedera and Viscum pollen types in the diagrams of the Vogelsberg mountain area, Hesse, can be interpreted as locally grown as they are insect pollinated taxa. Their Neolithic occurrence there is evidence for more favourable climatic conditions than exist today $^{112}$. Viscum vanishes in the early Subboreal (around $3700 \mathrm{BC}$ ), which probably indicates a decrease of summer

103 Bond et al. 1997; Bond et al. 2001.

104 Denton/Karlen 1973; Haas et al. 1998; Nussbaumer et al. 2011.

105 Meeker/Mayewski 2002.

106 Magny 2004, 2013; see also Magny et al. 2006.

107 Magny 2013, Fig. 4; Seidel 2012, 300.

108 E.g. Bittmann 2001, 102 ff.; Wanner et al. 2008; Wanner et al. 2011.

109 Litt et al. 2009; Kühl/Moschen 2012.

$110 \mathrm{Kühl} /$ Moschen 2012

111 Kühl/Moschen 2012, 1075 and Fig. 4.

112 Schäfer 1996, 180. 

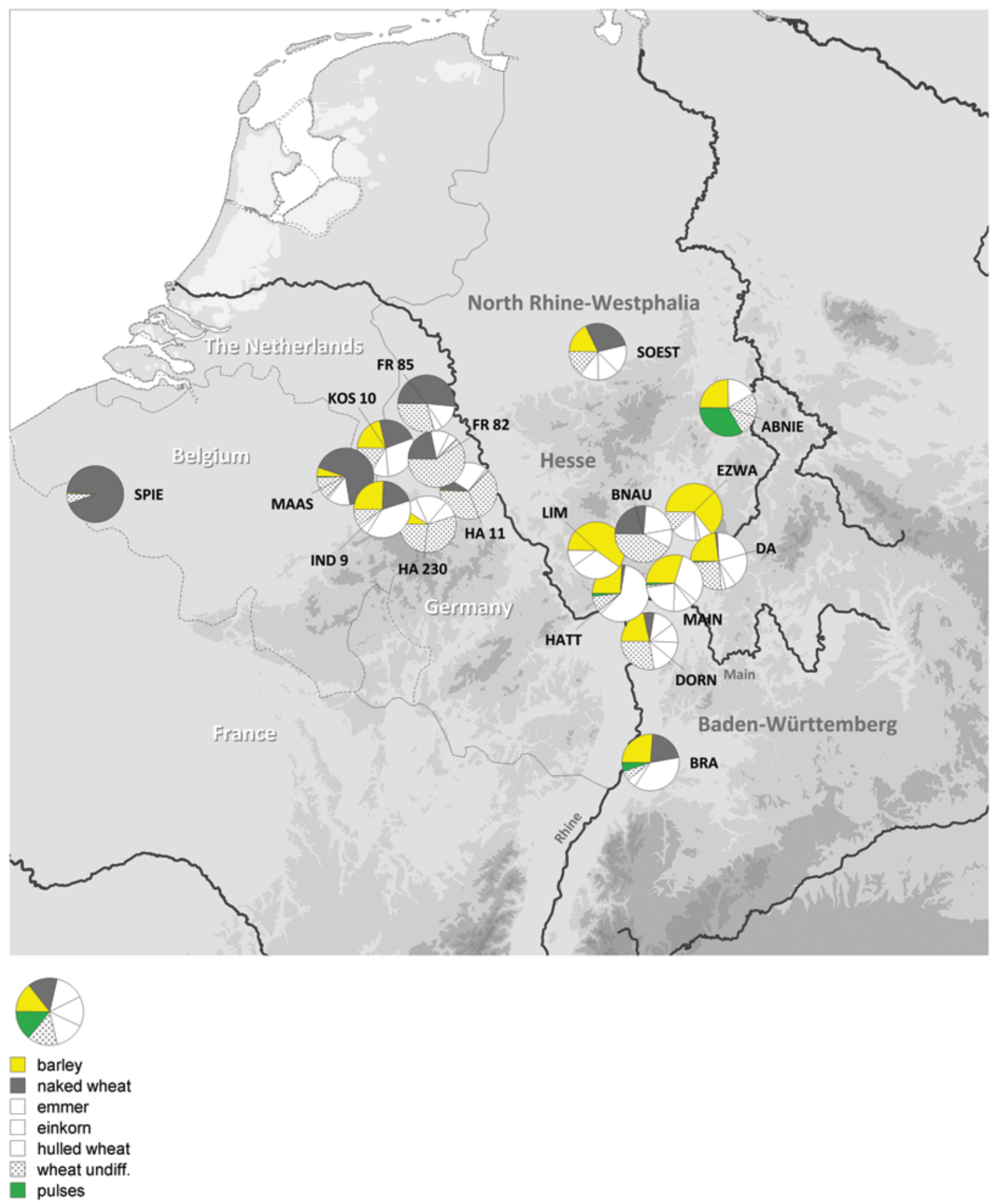

Fig. 8: Percentages of crop species (number of seeds) mapped per site with a minimum of ten crop seeds. Abbreviations: ABNIE Altenburg, Niedenstein; BNAU Bad Nauheim; BRA Bruchsal, Aue; DA Dauernheim, Ranstadt; DORN Dornheim, Groß-Gerau; EZWA Echzell „Wannkopf“; FR 82 Jüchen-Garzweiler, Elfgen; FR 85 Jüchen-Garzweiler, Belmen; HA 230 Hambach; HA 11 Hambach, Niederzier; HATT Hattersheim; IND 9 Inden Geuenich; KOS 10 Koslar; LIM Limburg-Greifenberg; MAAS Maastricht-Vogelzang; MAIN Maintal-Hochstadt; SOEST Soest Altstadt; SPIE Spiere de Hel 
temperatures as it needs July temperatures $\geq 16^{\circ 113}$. This might be connected with the second climatic decline in later Michelsberg (Fig. 10). Hedera disappears in the middle Subboreal, probably due to sinking winter temperatures. It requires $a \geq-1,5 /-2^{\circ}$ January temperature ${ }^{114}$. The same holds true for Ilex.

The applicability of these palaeoclimatic data for the archaeobotanical interpretation of Michelsberg agriculture is difficult. For example, for cereal growing the time and the amount of precipitation in spring and summer, and the temperatures at the beginning and end of the vegetation period, as well as during the harvest period, are decisive for the yields achievable, while long lasting snow cover is disadvantageous for animal breeding ${ }^{115}$.

To understand the modern climatic potential of the landscapes concerned, the 33 Michelsberg sites were plotted on maps with the contemporaneous average temperature and precipitation. The sites are situated today in the zone of predominantly 9-10 degrees average temperature per year and of predominantly $600-800 \mathrm{~mm}$ annual precipitation $^{116}$ (Fig. $11 \mathrm{a}$ and b). We can state that all Michelsberg sites investigated archaeobotanically are situated today in loess landscapes with a favourable climate, well suited for agriculture.

In case of global climatic deterioration in the $5^{\text {th }}$ and $4^{\text {th }}$ millenium BC, the climate would still have been better in the Michelsberg area than in the northern Alpine foreland, where the earliest Egolzwil farmers and their successors continued growing naked wheat - as a winter cereal -, as well as flax and poppy. Therefore the reduction in crop species grown by the Michelsberg farmers probably points to cultural decisions that were not enforced by climatic changes. As for the growing characteristics of the crops, tetraploid naked wheat, emmer and barley might have been grown as summer crops, as the pulses certainly were. Einkorn can be grown as summer or winter cereal. Possibly the Michelsberg growing strategy with its reduced crop spectrum was based on summer crop growing due to more emphasis on stock breeding (see below).

113 See also the pollen diagram Herrenwieser See in the Black

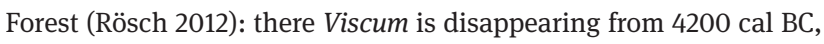
Hedera from $2700 \mathrm{cal}$. BC onwards and is again evidenced for the Medieval period.

114 Schäfer 1996, 180.

115 For the discussion see e.g. Maise 1998.

116 If compared with older climate data, for example from 1891-1930 from the "Geschichtlicher Atlas von Hessen" (1978), the landscapes are characterised by precipitation of less than100 $\mathrm{mm}$ on average, and higher average temperatures. Such modern climate data cannot be transferred to the prehistoric periods directly, but they provide an indication of the ecological potential of the landscapes settled by the Michelsberg farmers compared with other areas of Central Europe.

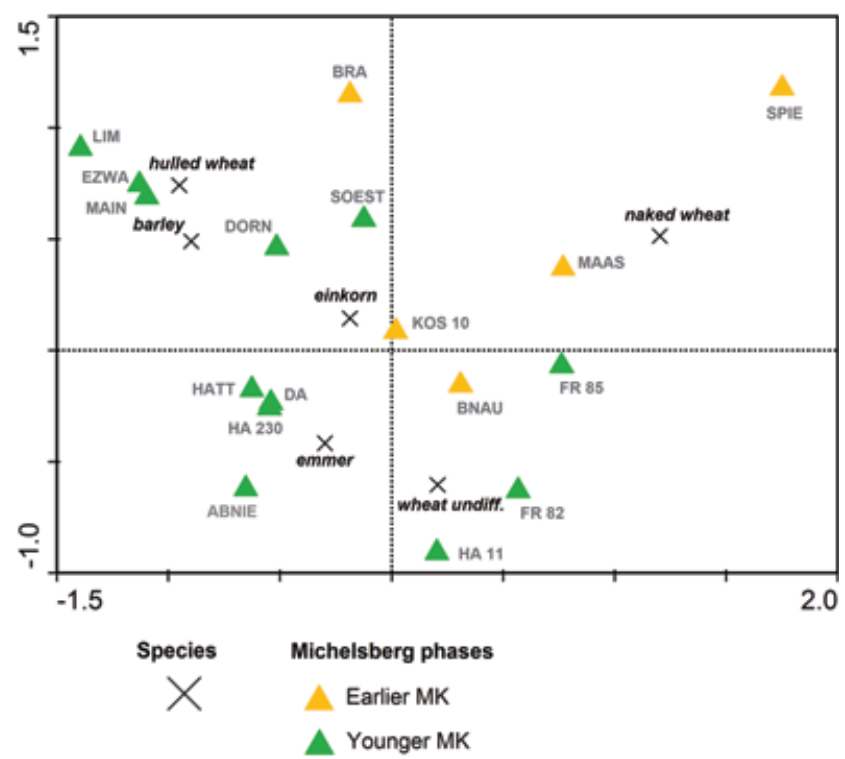

Fig. 9: Biplot with sites and cereal taxa based on a correspondence analysis of the number of seeds per cereal taxon and per site (minimum number of ten cereal seeds per site). Sites are labelled by archaeological dating to Earlier or to Younger Michelsberg (see Tab. 2)

A sudden general increase in the amount of wild plants of certain nutritional value collected could be interpreted as a reaction to some sort of crisis in the supply with food products, induced for example by climate deterioration ${ }^{117}$. The species most frequently found as charred finds are hazel Corylus avellana, apple Malus cf. sylvestris and sloe Prunus spinosa. As evidenced by their remains, the occurrence of edible fruits, nuts and berries of nutritional value does not increase from the Earliest Neolithic Bandkeramik to the Michelsberg period in our investigation area. Hazel Corylus avellana is always quite frequent at Michelsberg settlement sites, as well as before (Fig 12), but there is no difference between the individual Michelsberg phases, which could be related to known climatic changes (see above). Perhaps this question should be revised when the archaeobotanical database for the different Michelsberg phases has been improved in future.

\section{Human impact and vegetation cover}

As far as they were available, pollen diagrams from the lowlands, where the Michelsberg sites and related fields were situated, can be compared with those of the adjacent low mountain areas (Mittelgebirge) having been potential

117 As argued e.g. by Arbogast et al. 2006; Schibler et al. 1997. 


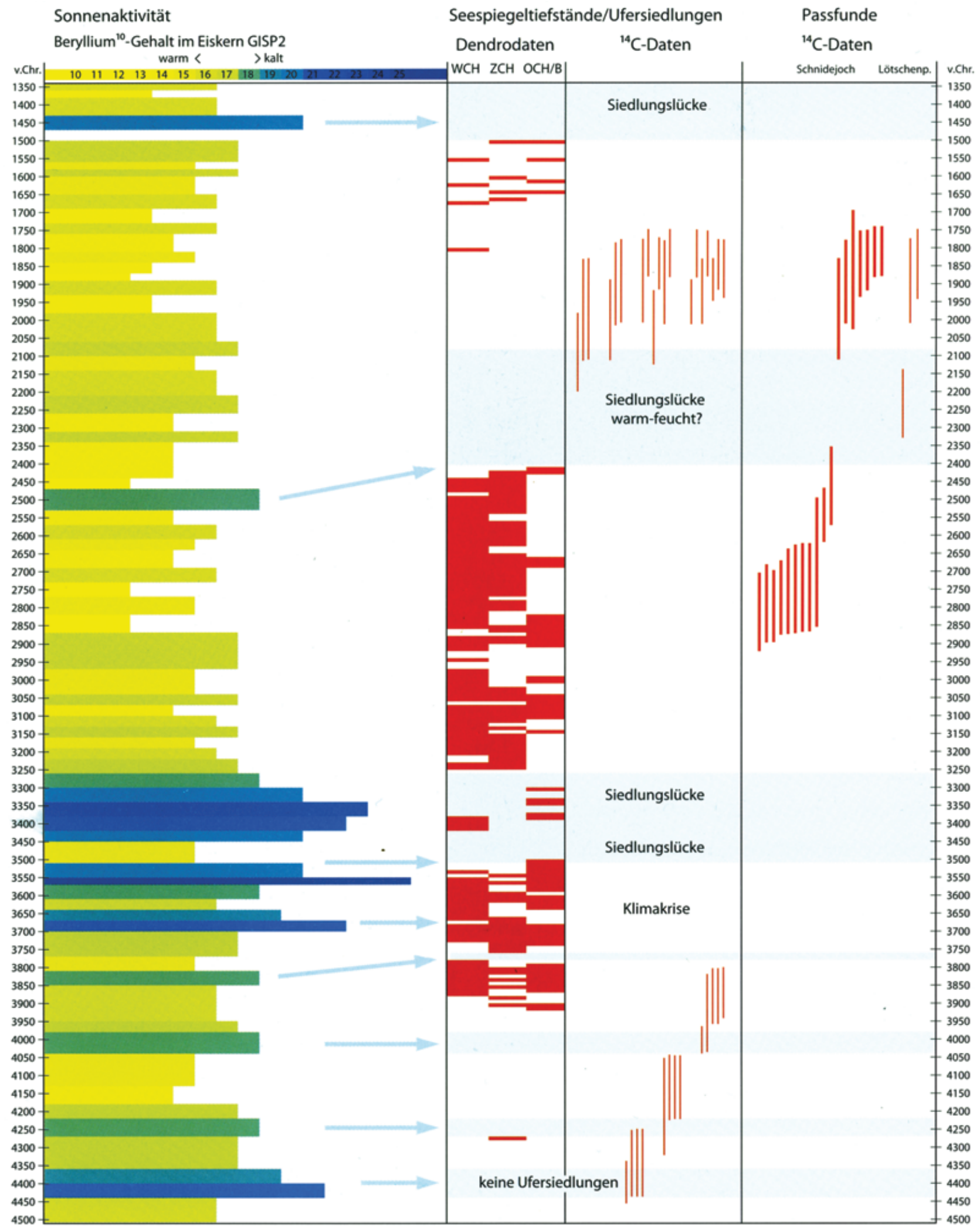

Fig. 10: Reconstruction of the climate between 4500 and $1350 \mathrm{BC}$. To the left: intensity of solar insolation based on the ${ }^{10} \mathrm{BE}-\mathrm{content}$ from the Greenland icecore GISP. Middle: sea levels of the lakeshore sites from Swizzerland and the region of Lake Constance based on ${ }^{14} \mathrm{C}$ - and dendrochronologically dated settlement phases. To the right: ${ }^{14} \mathrm{C}$-dated (1-sigma) finds from the Schnidejoch (thicker line) and the Lötschenpass (thin line; from Seidel 2012, Fig. 10, following Suter et al. 2005) 

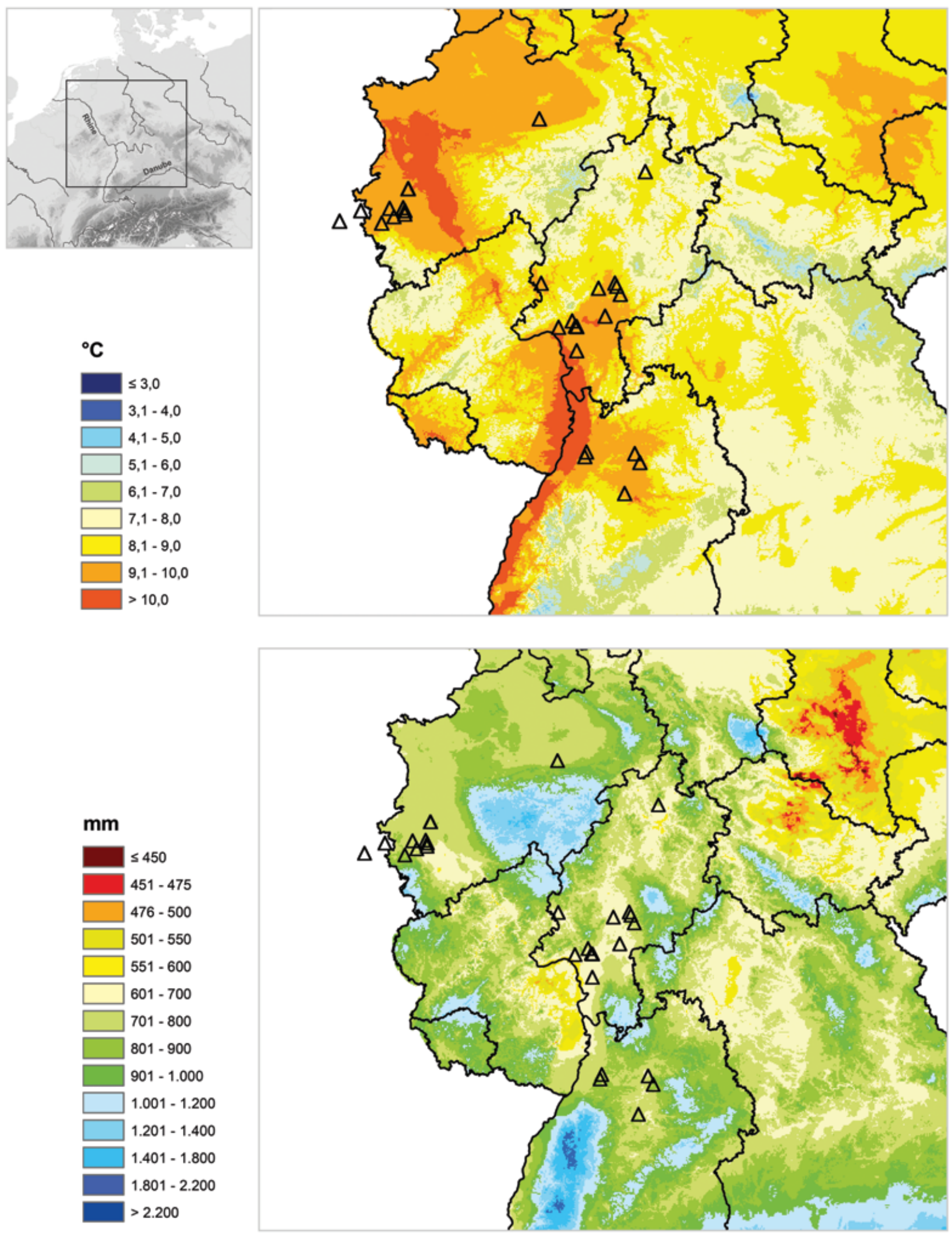

Fig. 11: Maps with $\boldsymbol{a}$ mean annual temperature $\left({ }^{\circ} \mathrm{C}\right)$ and $\boldsymbol{b}$ mean annual precipitation (mm), both 1961-1990 in Germany. The Michelsberg sites investigated archaeobotanically are located in areas with a mean annual precipitation between 600 and $800 \mathrm{~mm}$ and a mean annual temperature of $9-10^{\circ} \mathrm{C}$ (except ABNIE Altenburg-Niedenstein $7,1-8^{\circ} \mathrm{C}$ ). Maps kindly provided by the German Weather Service (Deutscher Wetterdienst DWD, Offenbach) 


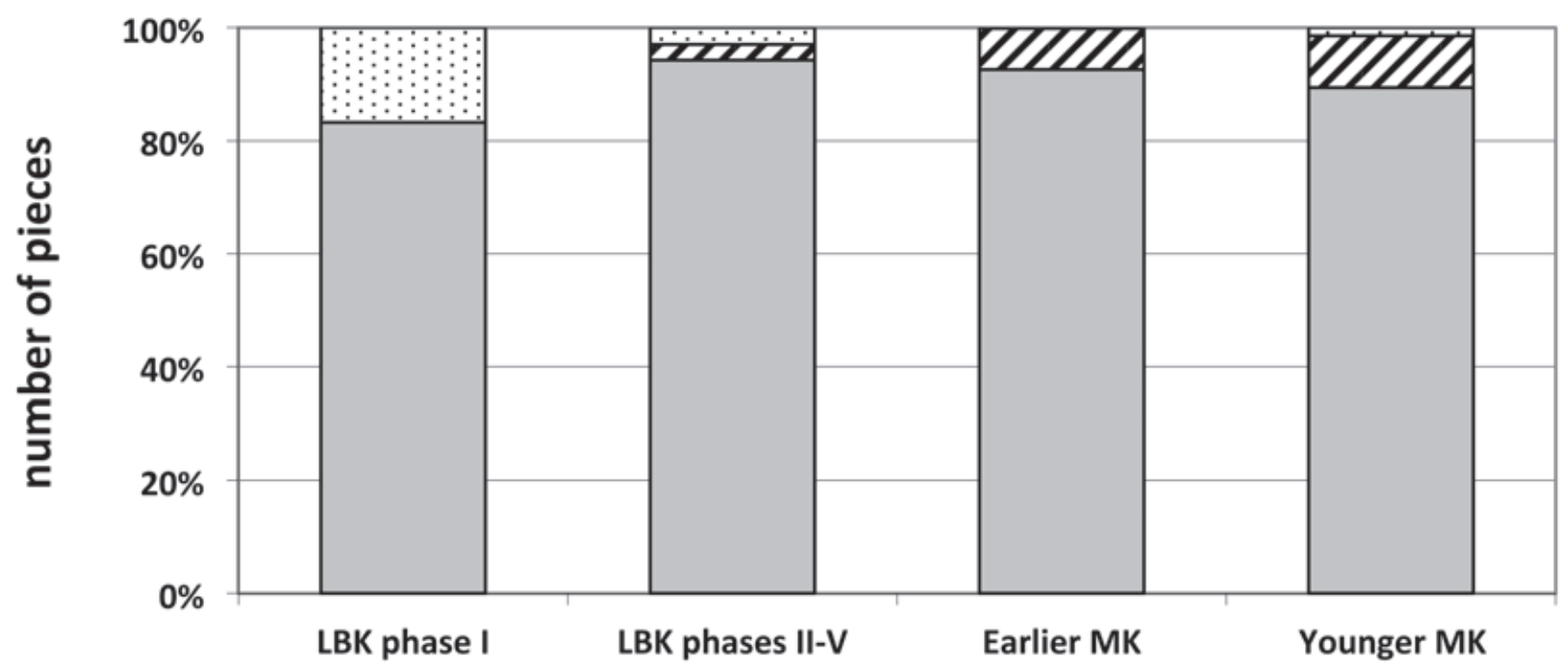

\section{$\square$ Corylus avellana $\square$ Malus sylvestris $\square$ Prunus spinosa}

Fig. 12: Comparison of the percentages of charred plant remains of hazel Corylus avellana, apple Malus sylvestris and sloe Prunus spinosa for different archaeological phases of the Michelsberg culture (MK) and the Bandkeramik culture (LBK). The sample volumes analysed range from 556 litres (Earlier MK) and 3.899 I (Later MK) to 10.095 I (LBK phases II-V) and 18.392 I (LBK I), which is important for the interpretation (LBK data from the ArboDat database Wiesbaden)

zones of transhumance during the vegetation period. Dependant on the diameter of the deposits, their surrounding terrain and the distance to human activities, the available pollen diagrams do not show the same vegetation development. On the other hand, we can observe certain comparable supraregional phenomena.

The woodland in the distribution area of the Michelsberg settlements of the lowlands was still without hornbeam Carpinus betulus and beech Fagus sylvatica probably was slowly advancing in the South ${ }^{118}$. The most debated supraregional vegetation phenomenon of the centuries around $4000 \mathrm{BC} / 5000 \mathrm{BP}$ involves the elm decline and related changes ${ }^{119}$. If we compare data from the lowlands with those of the lower mountain range, the elm pollen types and some other pollen taxa that were determined might not represent the same species with the same ecological behaviour, which complicates the discussion. In addition, due to the problems in calibration of the ${ }^{14} \mathrm{C}$-datings (plateaus etc.) even in one and the same landscape it is difficult to decide if the elm decline in two diagrams happened at the same time or

118 Pollen diagrams comprising this period are lacking in the lowlands of the southern distribution area of the Michelsberg culture. 119 E.g. Kalis 2010, 37 f.; Kubitz 2000; Rösch 2012; Schäfer 1996, 175; further references there. not. There is a variation of datings from about 5200 until $4900 \mathrm{BP}^{120}$.

The elm decline regularly occurs synchronously to an increase of the percentages of hazel and oak pollen type. Therefore it is rather unlikely that the elm decline happened in connection with climatic deterioration. A pathogen attack could have played a major role as recently discussed again by Nielsen et al. for northern Central Europe $^{121}$. Selective use of elm for leaf fodder seems to be less likely as a cause, as lots of other tree or shrub species are suited for this purpose too ${ }^{122}$.

For example, in the pollen diagrams from the Vogelsberg lower mountain area in Hesse, adjacent to the Wetterau loess landscape settled by Michelsberg farmers, the elm decline is clearly visible and is connected with an increase in Corylus and anthropogenic indicators, as well as pollen types such as Plantago lanceolata (e.g. site "Forellenteiche”, $713 \mathrm{~m}$ a.s.l., ca. 0,24 ha) ${ }^{123}$. A slight charcoal peak is also visible. Single Cerealia-type, Picea and Abies pollen grains that appear are probably the result

120 E.g. Herbig/Sirocko 2012; Rösch 2012; Schäfer 1996, 175; further references there.

121 Nielsen et al. 2012 (further references there), 143; see also the discussion in e.g. Kubitz 2000, 67 ff.; Schäfer 1996, 175 ff.

122 E.g. Haas/Rasmussen 1993; Rackham 2003; Vera 2002; more references there.

123 Schäfer 1996, $175 \mathrm{ff}$. 
of long distance transport. This pollen assemblage can be interpreted as a sign of an opening up of the forest, maybe by burning, which encouraged undergrowth and therefore wood pasture and the availability of gathered plants. A further indicator for wood pasture is the occurrence of Pteridium, a "pasture weed" which is avoided by the animals ${ }^{124}$. The growth of Pteridum is encouraged by burning too.

Another Vogelsberg diagram, "Breungesheiner Heide”, comes from to a raised bog ( $715 \mathrm{~m}$ a.s.l., ca. $\left.5 \mathrm{ha}^{125}\right)$. Due to its size it is more regionally influenced. Here too the elm decline is visible and combined with an increase of anthropogenic indicators, etc. Similar phenomena are found in other mountain regions, for example the Black Forest (diagram Herrenwieser See, $840 \mathrm{~m}$ a.s.l., 1,2 ha) or the Eifel region ${ }^{126}$. The Plantago lanceolata curve is not always closed, which might be connected with the number of pollen counted per sample or the distance to - possibly pastoral - activities (see below) ${ }^{127}$.

Plantago lanceolata is present in the vegetation of the investigation area at least from the Mesolithic or early Holocene $^{128}$. It occurs sometimes on-site as charred seeds in settlement samples from the Bandkeramik onwards, but it is very rare ${ }^{129}$. If it had been a weed current in the fields or fallows, it should occur regularly with the crop remains as for example Bromus, Chenopodium or Polygonum species do. As this is not the case during the Neolithic this pollentype most likely can be interpreted as an indicator for pasture there. Important for this interpretation is the occurrence of the elm decline and related phenomena even in pollen diagrams of deposits far from Neolithic settlements, such as all the diagrams of the lower mountain range, especially those with small diameter and therefore stronger local (/extralocal) impact. This also makes it unlikely the elm decline having been connected with arable activities. Instead, the coincidence of the elm decline and the increase of shrubs and trees that require light, and the beginning of a more or less closed Plantago lanceolata curve combined with the occurrence of other signals (Pteridium, Taxus, Corylus, Salix, Populus, Poaceae, micro-charcaol usw.), could be linked with a significant increase in widespread wood pasture. This might have been connected

124 E.g. Schäfer 1996, $181 \mathrm{ff}$.

125 Schäfer 1996.

126 Kalis/Meurers-Balke 1997, $41 \mathrm{ff}$.; Kühl/Moschen 2012; Litt et al. 2009; Rösch 2012.

127 For the methodological discussion see e.g. Hellman et al. 2009.

128 Evidence e.g. from pollen diagrams by Knörzer/Meurers-Balke 1999, 123.

129 Knörzer 1997; Kreuz 2010/2012; Willerding 1986, 186 ff. with burning activities by the herdsmen to encourage undergrowth and likewise fodder supply for the animals as indicated e.g. by micro-charcoal and Pteridium pollen type. Unfortunately it is not possible to check this systematically at present, as micro-charcoal has seldom been counted for the pollen diagrams in the Michelsberg distribution area of the loess landscapes ${ }^{130}$. In addition, the deposit of microcharcoal might have different causes in the mountain area compared with the lowlands (see next chapter).

Another indication for an opening up of the landscapes is an increase in the occurrence of Malus sylvestris as plant macro-remains over time (Fig. 12). This might be explained as the result of an increase in open stands suited for crab apple trees, which require light, to grow. Further indications of an opening up of the landscapes are provided by the archaeozoological results (see below).

\section{Burning the fields?}

Strikingly, in general charred wild plant species, representing potential field weeds, are extremely rare among the archaeobotanical finds from Michelsberg sites (Fig. 13 and Tab.4). This result has to be explained, and it connects the Michelsberg culture not only with the farmers of the Alpine foreland but also with the Funnelbeaker culture in the north ${ }^{131}$ and with the Neolithic archaeobotanical data from Great Britain and Ireland ${ }^{132}$.

Schier ${ }^{133}$ suggests the delayed ("tertiary") introduction of the Neolithic subsistence into the Alpine foreland and to northern Central Europe as a consequence of the delayed introduction of the "slash and burn" cultivation method, which might have been necessary to get satisfying yields on the qualitatively worse soils there. The "disadvantage" of this method is the demand for land and labour - as the field areas are shifted regularly and the abandoned areas are wooded quickly again from the wood trunks and roots remaining in the fields, with the resulting necessity to cut the woodland again and again every maybe ten or more years ${ }^{134}$.

130 See also the discussion in Kreuz 2010/2012, $57 \mathrm{ff}$. and $112 \mathrm{ff}$. 131 See the archaeobotanical data compilation in Kirleis et al. 2012, 225.

132 ABCD database state 2013, see http://intarch.ac.uk/journal/ issue1/tomlinson_toc.html; personal comm. July 2013 and internal reports kindly provided by Angela Monckton (Univ. Leicester) and Ruth Pelling (English Heritage, Portsmouth); see also Jones/RowleyConwy 2007; McClatchie et al. 2013; Moffett et al. 1989.

133 Schier 2009.

134 E.g. Rösch et al. 2011; critically: Hosch/Jacomet 2004, $128 \mathrm{ff}$;; Maier 1999. 


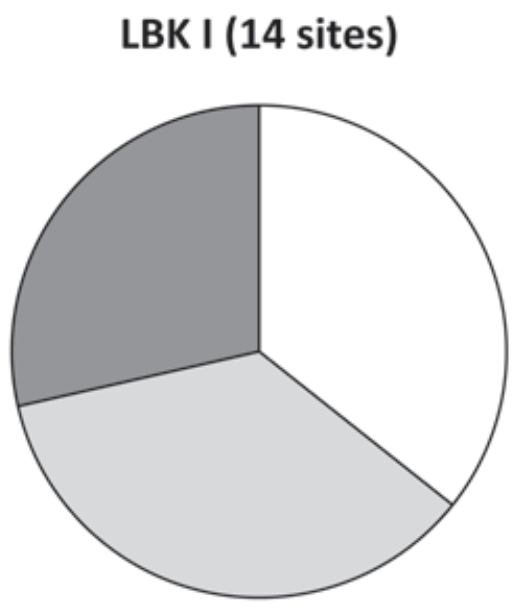

\section{LBK II-V (25 sites)}

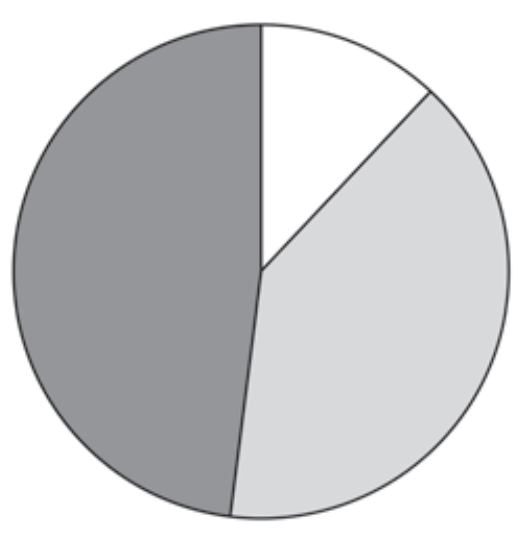

MK (27 sites)

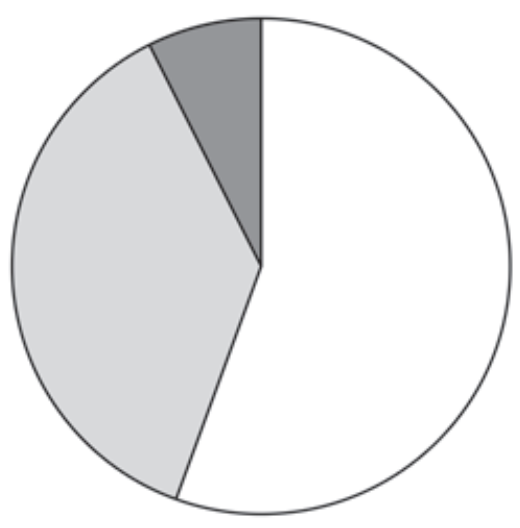

0-3 $\square$ 4-10 $\square>10$

Fig. 13: Number of potential weed taxa from Michelsberg sites compared with Earliest Bandkeramik (LBK I) and Younger Bandkeramik data (LBK II-V). Included are the Ecological Groups 1-4, 6 and 7 (for the Ecological Groups used see Tab. 4 as well as Kreuz 2004/2005, 122 Tab. 8 and $147 \mathrm{ff}$.). Michelsberg sites predominantly have lower numbers of weed taxa
At the moment, there is no evidence making likely a serious degradation of the Loess soils during the time of the Michelsberg culture, which would provide the basis for the necessity of such a field management there. On the other hand one aspect of this method is worth considering, which might have been useful for the Michelsberg farmers in the loess landscapes too: As revealed by the results of the Forchtenberg experiments, the technique of preparing the field area with a fire roll before sowing the seed (Fig. 14) reduces the amount of weeds in the first year considerably ${ }^{135}$. In addition fire, in any case, promotes the suppression of pests and diseases. Such a management of the fields might be a possible explanation for the phenomenon of low densities of weed seeds and weed species at Michelsberg sites, compared with Bandkeramik assemblages (Fig. 13). High resolution pollen diagrams with micro-charcoal counts within or adjacent to the loess landscapes settled by the Michelsberg farmers are urgently needed, to discuss such a cultivation method. Actually, regular burning of the stubble fields has been a traditional and widespread praxis, e.g. in Germany until the seventies, which then - alleged due to the fire risk for nearby villages and buildings - has been forbidden by law and replaced by the management of herbicides and insecticides.

\section{Wild and domestic animals}

Cattle Bos primigenius taurus, pig Sus scrofa domestica, sheep Ovis orientalis aries, goat Capra aegagrus hircus and dog Canis lupus familiaris are the domestic animals regularly found at Michelsberg sites where bones are preserved and determined. However, bones are not preserved at all in the whole Lower Rhine area, for example, due to higher precipitation and therefore stronger decalcification of the soil. That is why it is not possible to prove at present whether regional variations in Michelsberg stock farming existed or not.

Cattle is often, but not always, the dominating species among domestic animals, followed by pig, sheep/goat and dog. Where it can be determined, remarkably more sheep occur than goat at the Michelsberg sites ${ }^{136}$.

135 Ehrmann/Rösch 2005; Schier 2009, 23 ff.; see also the discussion in Eckmeier et al. 2007.

136 E.g. Arbogast 1998, Fig. 3; Benecke/Wotzka 1998, 92; Beyer 1972; Höltkemeier/Fetsch in prep.; Knoche 2013c, 192ff.; Kokabi 2008 a and b; Schlenker 2008; Stephan 2008a and b; Steppan 1998; 2003; 2007; 2010; Vanmontfort 2004; Vanmontfort et al. 2001/2002, 59. 


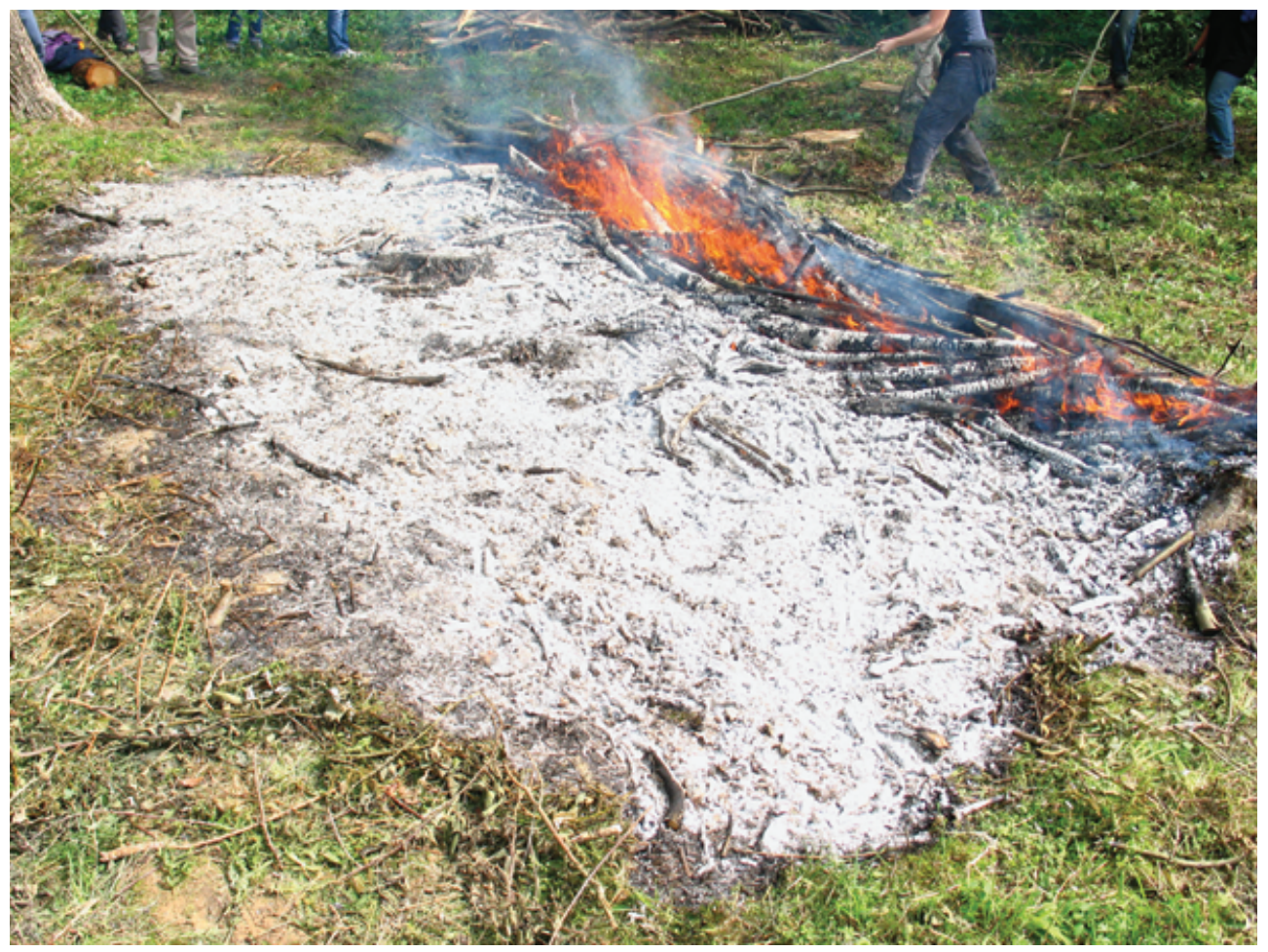

Fig. 14: Burning the fields, as demonstrated at the experimental cereal growing site Forchtenberg (Baden-Württemberg/Germany), not only manures the soil but also reduces pests, diseases and weeds (photo Angela Kreuz 13. 6. 2012)

Horse has been discussed as an innovative element of Michelsberg stock farming ${ }^{137}$. The state of research does not allow at the moment to decide if the bone finds are from domestic horse Equus caballus or from wild horse Equus ferus due to the difficulties of morphometric determinations. Apparently the amount of horse finds increases in southwest and southern Germany during the Late Neolithic. There are more horse finds at Michelsberg sites than for example in Bandkeramik ones, which is discussed as the result of influences from the Pfyn-Altheim group of Upper Swabia (Oberschwaben) ${ }^{138}$.

Horses, like cattle and sheep, are (and probably were) so-called grazers, as they favour predominantly grass as fodder ${ }^{139}$. Therefore an increase in wild horse finds indicates an increased opening of the woodland, which allowed more grasses requiring light to grow. Other wild animal finds point in the same direction, for example hare, or beavers which - under "natural" conditions - create

137 E.g. Benecke/Wotzka 1998, 92; Grefen-Peters, cited in Geschwinde/Raetzel-Fabian 2009, 265 ff.; Herrmann/Jockenhövel 1990, 160; Steppan 2007.

138 Benecke/Wotzka 1998, 834; Benecke 2002; Stephan 2008a, $235 \mathrm{ff}$.

139 E.g. Vera 2002; discussion in Kreuz 2008, 2010/2012. extended meadows in the river valleys. It is quite possible, that the increase of horse finds is related to an increase in the availability of horse as kill due to an opening up of the woodland by burning and wood pasture ${ }^{140}$ as part of the Middle Neolithic, and especially of the Late Neolithic, farming systems.

\section{Final remarks}

Michelsberg daily life is difficult to comprehend, as the remains are so patchy. The archaeobiological and archaeological state of research is not sufficient to arrive at a final hypothesis, but it allows confirmation of some old and formulation of some new ideas, as well as some research desiderata for the future.

Compared with previous and contemporaneous neighbouring cultures, Michelsberg farmers grew a reduced crop spectrum, probably without cultivation of oil-/fibre plants. As there is very little evidence for pulses, emphasis was obviously placed on cereal cultivation. Like the small amount of weed species found, this fact connects Michels-

140 Kreuz 2010/2012, 73; more references there. 
berg agriculture with the Funnelbeaker culture and the Early Neolithic of Great Britain and Ireland ${ }^{141}$. The naked wheat grown seems to have been of the tetraploid form, which was probably adopted from the previous Bischheim culture. Due to the state of research, the introduction of tetraploid naked wheat to the Bischheim and Michelsberg distribution areas still needs further investigation. Both archaeological cultures have strong stylistic affinities to the French Chasséen (see above).

On question is, what replaced flax and poppy and why? As for flax Linum usitatissimum as a fibre plant, one explanation worth considering might be the occurrence of the wool-sheep, not to forget the possibility of the woolpig already in the Late Neolithic. This is of course difficult to proof in view of the rarity of archaeological finds as a result of the problems of (organic) preservation ${ }^{142}$. The find of the zoomorphic figurine of a ram from Jordansmühl (Jordanów Śląski, Poland) has also been discussed in this context. It is contemporary with younger Michelsberg and is interpreted as wearing a "fleece"143.

On the other hand, flax is a time consuming and demanding crop plant. Within the Michelsberg distribution area diverse other natural fibres were available, like nettle Urtica, the bast of trees etc., which might also have been used too, as is suggested for example by the manifold ethnographic evidence for such crafts ${ }^{144}$. As for poppy and flax as crop plants providing oil or fat, evidence for the Neolithic use of wild oil-plants like (apart from hazel nut) Brassica campestris, Descurainia sophia and Camelina sativa var. microcarpa was presented by Maier, Schlichtherle and Villaret-von Rochow ${ }^{145}$. Jacomet et al..$^{146}$ discuss the possible substitution of oil crop plants by animal fat in general.

The current state of research - although just pieces of a puzzle - seems to confirm an old hypothesis about Michelsberg subsistence: palynological and archaeozoological data are indicating a certain opening up of the forest canopy. This might be connected with an increased emphasis on pasture economy. The latter would explain the reduced crop spectrum compared to the Bischheim culture, as well as compared with the contemporaneous

141 For the archaeobotanical data see footnote 134 and Kirleis et al. 2012, McClatchie et al. 2013).

142 E.g. Preuß 1998, 86, 120.

143 Picture of the idol recently published in Siebenmorgen/Lichter 2010, 22.

144 Just as examples: Ertug-Yaras 1997; Godwin 1970; Meligren 2012; Kunst- und Ausstellungshalle Bonn 2013.

145 Maier 2011, 98 ff.; Schlichtherle 1981; Villaret-von Rochow 1967. 146 Jacomet et al. 1989, 207. cultures of the lakeshore sites in the northern Alpine foreland.

In this context the inspiring "Braunschweiger Modell”, hypothesized by Geschwinde and Raetzel-Fabian must be mentioned ${ }^{147}$. It favours the model of a society comprising two groups of people: sedentary farmers on one hand, and itinerating herdsmen practising transhumance with large flocks on the other, both groups returning to the enclosures for seasonal communal feasting and related social and religious activities ${ }^{148}$. The alternative of the use of the enclosures as simple domestic animal fences (Viehkrale) is quite unlikely, because - from experience - herds can be easily controlled with a few well trained shepherd $\mathrm{dogs}^{149}$. In any case, such big constructions are not necessary for fencing in domestic animals.

The function of the Michelsberg causewayed enclosures is still under discussion. There is no doubt that they represent a cooperative, communal performance as "large working parties had to cooperate for a considerable amount of time"150. It cannot be ruled out that at the time of their construction the remains of the rarer earlier Neolithic earthworks were still "visible remains of 'ancestral' occupations in the landscape"151. Following Jeunesse and Seidel, the construction of the earthworks and the deposition of deer heads, aurochs horns, sometimes whole vessels, human bones or skeletons and parts of animal carcasses are evidence for the practice of rituals ${ }^{152}$. In many cases several ditches have been dug one after the other instead of repairing the first one. Müller ${ }^{153}$ therefore also discusses ritual centres as one potential function of earthworks. Seidel ${ }^{154}$ argues in a similar way by comparing the numbers of enclosures and open settlements in the region of Middle Neckar and Kraichgau, Baden-Württemberg. The ratio of 12 earthworks to 78 unfortified settlements led her to assume earthworks as places for activities sustaining social cohesion, such as rituals, feasts or markets. The same holds true for the Scheldt basin, Belgium, where 68 Michelsberg unfortified sites (settlements?) and 14 enclosure sites reflect the state of research ${ }^{155}$. In any case, these

147 Geschwinde/Raetzel-Fabian 2009, e.g. 253.

148 See also the discussion in Knoche 2013c, 190 ff.; Vanmontfort 2004, 331 as well as the comments by Müller 2011; Furholt and Müller 2011 about "ritual cooperation", "ritual collectivity" and earthworks as an expression of cultural identity.

149 Kreuz 2010/2012, chapter 8, more references there.

150 De Grooth 1991, 174 f.; see also Vermeersch/Burnez-Lanotte 1998, 51.

151 Vanmontfort 2004, 311.

152 Jeunesse 2010, 55; Jeunesse/Seidel 2010, $63 \mathrm{ff}$.

153 Müller 2010, $255 \mathrm{ff}$.

154 Seidel 2010, 87.

155 Vanmontfort 2004, 314. 
enclosures "must also have created and enforced a sense of group identity" within the Michelsberg distribution area $^{156}$.

In future, large-scale excavations in suitable site types and features, accompanied by systematic archaeobiological investigations and more absolute datings are needed in order to advance research on the Michelsberg culture. And last but not least, archaeobotanical data from the French Michelsberg settlement sites, as well as from the French Chasséen and St. Uze complex and subsequent archaeological cultures, could contribute to a better understanding of the western Central European Late Neolithic and its southern connections.

\section{Acknowledgments}

Many thanks to Örni Akeret, Ferran Antolin, Corrie Bakels, Laurent Bouby, Christoph Brombacher, Deutscher Wetterdienst Offenbach, Thomas Doppler, Renate Ebersbach, Sandra Fetsch, Detlef Gronenborn, Eda Gross, Monika Hellmund, Stefanie Jacomet, Benedikt Knoche, Sabine Kuhlmann, Uschi Maier, Meriel McClatchie, Angela Monckton, Ruth Pelling, Birgit Regner-Kamlah, Wolfram Schier, Helmut Schlichtherle, Aurélie Salavert, Ute Seidel, Hans-Peter Stika, Bart Vanmontfort, Nicola Whitehouse and Samuel van Willingen for useful informations, to the German Research Association DFG for funding, to David Wigg-Wolf for improving the English and to Julian Wiethold as referee for useful remarks.

\section{References}

Akeret/Geith-Chauvière 2011a: Ö. Akeret/I. Geith-Chauvière,. L'histoire de la relation entre hommes et plantes utiles: synthèse des données carpologiques (Plateau de Bevaix 7). Arch. neuchâteloise numérique 7 (Neuchâtel 2011) 1-81.

-/- 2011b: -/-, Les macrorestes végétaux. In: M.-H. Grau Bitterli/ E. Fierz-Dayer (Eds) Bevaix/Treytel-à Sugiez: histoire d'un complexe mégalithique néolithique, témoins d'habitats du Campaniforme et du Bronze ancien (Plateau de Bevaix 6). Arch. neuchâteloise 47 (Hauterive 2011) 311-321.

-/- 2003: -/-, Les macrorestes végétaux. In: S. Wüthrich (Ed.) Saint-Aubin/Derrière la Croix. Un complexe mégalithique durant le Néolithique moyen et final. Arch. neuchâteloise 29 (Hauterive 2003) 281-293.

Antolín/Buxó 2011: F. Antolín/R. Buxó, “L’explotació de les plantes: contribució a la història de l'agricultura i de l'alimentació vegetal del Neolític a Catalunya”. In: A. Bosch/J. Chinchilla/
J. Tarrús (eds), El poblat lacustre del Neolític antic de La Draga. Excavacions 2000-2005. Monogr. Centre Arqu. Subaquàtica Catalunya 9, (Girona 2011) 147-174.

Arbogast 1998: R.-M. Arbogast, Contribution de l'archéozoologie du site Michelsberg de Mairy (Ardennes) á l'étude de l'origine de la variabilité des faunes du Néolithique récent du Nord de la France. In: J. Biel/H. Schlichtherle/M. Strobel/A. Zeeb (Eds.), Die Michelsberger Kultur und ihre Randgebiete - Probleme der Entstehung, Chronologie und des Siedlungswesens. Math. z. Arch. Baden-Württemberg 43 (Stuttgart 1998) 135-142.

Arbogast et al. 2006: R.-M. Arbogast/S. Jacomet/M. Magny/J. Schibler, The significance of climate fluctuations for lake level changes and shifts in subsistence economy during the late Neolithic (4300-2400 B. C.) in central Europe. In: P. van der Knaap/W. Tinner/A. F. Lotter/S. Hicks (Eds.), Multidisciplinary reconstructions in palaeoecology - the diversity of ways and means. Vegetation Hist. Archaeobot. 15, 4, 2006, 403-418.

Arora 2002: S. K. Arora, Ein weiterer Bischheimer Großbau bei Garzweiler entdeckt. Archäologie im Rheinland 2001 (Stuttgart 2002) 31-33.

- 2005: -, Hofplätze der Bischheimer Kultur im Tagebau Garzweiler. Archäologie im Rheinland 2004 (Stuttgart 2005) 45-47.

-/Zerl 2004: -/T. Zerl, Bischheimer Siedlungen - archäobotanische Ergebnisse und ein fraglicher Perlenfund. Archäologie im Rheinland 2003 (Stuttgart 2004) 48-50.

Badisches Landesmuseum Karlsruhe 2010: Badisches Landesmuseum Karlsruhe, Jungsteinzeit im Umbruch. Die “Michelsberger Kultur” und Mitteleuropa vor 6000 Jahren (Karlsruhe 2010).

Bakels 1982: C. C. Bakels, Der Mohn, die Linearbandkeramik und das westliche Mittelmeergebiet. Arch. Korrbl. 12, 1982, 11-13.

- 1984: -, Carbonized seeds from Northern France. Analecta Praehist. Leidensia, 1984, 1-27.

-1990: -, The crops of the Rössen Culture: significantly different from their Bandkeramik predecessors - French influence? In: D. Cahen/M. Otte (Eds.), Rubané et Cardial. Études et recherches arch.Univ. Liège 39 (Liége 1990) 83-87.

- 1991: -, Western Continental Europe. In: W. van Zeist/ K. Wasylikowa/K.-E. Behre (Eds.), Progress in Old World Palaeoethnobotany (A. A. Balkema, Rotterdam, Brookfield 1991) 279-298.

-1994: -, Botanische Untersuchungen in der Rössener Siedlung Maastricht-Randwijck. In: A. J. Kalis/J. Meurers-Balke (Eds.), 7000 Jahre bäuerliche Landschaft: Entstehung, Erforschung, Erhaltung. Zwanzig Aufsätze zu Ehren Karl-Heinz Knörzer. Archaeo-Physika 13 (Bonn 1994), 35-47.

Bakels 1999: C. C. Bakels, Archaeobotanical investigations in the Aisne valley, northern France, from the Neolithic up to the early Middle Ages. Vegetation Hist. Archaeobot. 8, 71-77.

- 2003: -, Die neolithischen Weizenarten des südlimburgischen Lößgebiets in den Niederlanden. In: J. Eckert/U. Eisenhauer/ A. Zimmermann (Eds.), Archäologische Perspektiven. Analysen und Interpretationen im Wandel. Festschrift für Jens Lüning zum 65. Geburtstag. Internat. Arch. Stud. honoraria 20 (Rahden/Westf. 2003) 225-232.

- 2007: -, Nature or culture? Cereal crops raised by Neolithic farmers on Dutch loess soils. In: S. Colledge/J. Conolly (Eds.), The origins and spread of domestic plant in southwest Asia and Europe. Publications Inst. Arch. Univ College London. (Walnut Creek 2007) 343-349. 
- 2008: -, Maastricht-Vogelzang, the Netherlands, a Michelsberg site in the valley of the Meuse seen from a botanicle angle. In: H. Fokkens, B. J. Coles, A. van Gijn, J. P. Kleijne, H. H. Ponjee, C. G. Slapp Endel (Eds.), Between foraging and farming an extended broad spectrum of papers presented to Leendert Louwe Kooijmans. Analecta Praehist. Leidensia 40 (Leiden 2008) 111-122.

Becker 1991: W.-D. Becker, Die Pflanzenfunde der mittelneolithischen und eisenzeitlichen Besiedlungen von Hambach 502. Unpubl. Diplomarbeit im Fach der Biologie der MathematischNaturwissenschaftlichen Fakultät der Universität zu Köln (Köln 1991).

Benecke 2002: N. Benecke, Zu den Anfängen der Pferdehaltung in Eurasien. Aktuelle archäozoologische Beiträge aus drei Regionen. Ethnogr.-Arch. Zeitschr. 43/2, 2002, 187-226.

Benecke/Wotzka 1998: N. Benecke/H.-P. Wotzka, Die Tierknochenfunde von der jungneolithischen Höhenanlage mit Grabenwerk “Auf der Alteburg” in Dauernheim, Gde. Ranstadt (Wetteraukreis). Germania 76, 2, 1998, 823-838.

Bergmann 2008: C. Bergmann, Grubenhaus? Kellergrube? Oder ...? Ein michelsbergzeitlicher Baubefund aus Hattersheim am Main. In: F. Falkenstein/S. Schade-Lindig/A. Zeeb-Lanz (Eds.), Kumpf, Kalotte, Pfeilschaftglätter. Zwei Leben für die Archäologie. Gedenkschrift für Annemarie Häußer und Helmut Spatz. Internat. Arch. Stud. honoraria 2 (Rahden/Westf. 2008) 37-46.

Beyer 1972: A. I. Beyer, Die Tierknochenfunde. In: Robert Koch (Ed.), Das Erdwerk der Michelsberger Kultur auf dem Hetzenberg bei Heilbronn-Neckargartach. Forschungen und Ber. z. Vor- u. Frühgesch. Baden-Württemberg 3/2 (Stuttgart 1972) 7-47.

Biel 1984: Biel, J., Eine mittelneolithische Siedlung bei CreglingenFrauental, Main-Tauber-Kreis. Arch. Ausgr. Baden-Württemberg 1983 (1984), 47-50.

- 1998: -, Michelsberger Erdwerke im Raum Heilbronn. In: J. Biel/ H. Schlichtherle/M. Strobel/A. Zeeb (Eds.), Die Michelsberger Kultur und ihre Randgebiete - Probleme der Entstehung, Chronologie und des Siedlungswesens. Math. z. Arch. BadenWürttemberg 43 (Stuttgart 1998) 97-100.

Bittmann 2001: F. Bittmann, Die jungneolithische Feuchtbodensiedlung Pestenacker, Lkr. Landsberg/Lech - Auswirkungen auf die Landschaft aus botanischer Sicht. In: P. Schauer (Eds.) DFG - Graduiertenkolleg 462 "Paläoökosystemforschung und Geschichte”. Beiträge zur Siedlungsarchäologie und zum Landschaftswandel. Regensburger Beitr. z. prähist. Arch. 7 (Regensburg 2001) 93-107.

Bogdanovic/Piqué 2012: I. Bogdanovic/R. Piqué, Les datacions absolutes per C14. In: A. Bosch/R. Buxó/J. Chinchilla/ A. Palomo/R. Piqué/M. Saña/J. Tarrús/X. Terradas (Eds.) El jaciment neolític lacustre de la Draga. Quad. Banyoles 13 (Banyoles 2012) 58-61.

Boisaubert/Bugnon/Mauvilly 2008: J.-L. Boisaubert/D. Bugnon/ M. Mauvilly, Archéologie et autoroute A1, destins croisés. 25 années de fouilles en terres fribourgeoises, premier bilan (1975-2000). Arch. fribourgeoise 22 (Fribourg 2008).

Bond et al. 1997: G. Bond/W. Showers/M. Cheseby/R. Lotti/ P. Almasi/P. de Menocal/P. Priore/H. Cullen/I. Hajdas/ G. Bonani, A pervasive millennial-scale cycle in the North Atlantic Holocene and glacial climates. Science 294, 1997, 2130-2136.
- et al. 2001: -/B. Kromer/J. Beer/R. Muscheler/M. N. Evans/ W. Showers/S. Hoffmann/R. Lotti-Bond/I. Hajdas/G. Bonani, Persistent solar influence on north Atlantic climate during the Holocene. Science 294, 2001, 2130-2136.

Bradley 2007: R. Bradley, The Prehistory of Britain and Ireland (Cambridge 2007).

Bréhard/Beeching/Vigne 2010: S. Bréhard/A. Beeching/J.-D. Vigne, Shepherds, cowherds, and site function on middle Neolithic sites of the Rhône valley: An archaeozoological approach to the organization of territorries and societies. Journal Anthr. Arch. 29/2, 2010, 179-188.

Brewer et al. 2009: S. Brewer/L. Francois/R. Cheddadi/ J.-M. Laurent/E. Favre, Comparison of simulated and observed vegetation for the mid-Holocene in Europe. Climate of the Past Discussions, 5, 965-1011.

Brink-Kloke/Meurers-Balke 2003: H. Brink-Kloke/J. Meurers-Balke mit Beiträgen von W. D. Becker/A. von Bohlen/M. Doll/ H. Heinrich/M. Kunter/E. Lietz/R. Pasternak/C. Poniecki/ E. Schneider/U. Tegtmeier/B. Weninger/F. Wittler, Siedlungen und Gräber am Oespeler Bach (Dortmund) - eine Kulturlandschaft im Wandel der Zeiten. Germania 81, 2003, 47-146.

Brombacher/Vandorpe 2012: C. Brombacher/P. Vandorpe, Untersuchungen zu Wirtschaft und Umwelt aus der mittelneolithischen Fundstelle von Zizers GR-Friedau. In: A. Boschetti-Maradi/A. de Capitani/S. Hochnuli/U. Niffeler (Eds.) Forum, Zeit und Raum. Grundlagen für eine Geschichte aus dem Boden. Festschrift für Werner E. Stöckli zu seinem 65. Geburtstag. Antiqua 50 (Basel 2012) 95-104.

Brown 2007: A. Brown, Dating the onset of cereal cultivation in Britain and Ireland: the evidence from charred cereal grains. Antiquity 81, 2007, 1042-1052.

Buxó 2007: R. Buxó, Crop evolution: new evidence from the Neolithic of west Mediterranean Europe. In: S. Colledge/ J. Conolly (Eds.), The origins and spread of domestic plants in southwest Asia and Europe. Publications Inst. Arch. Univ College London. (Walnut Creek 2007) 155-171.

Chaffenet/Cordier 1999: G. Chaffenet/F. Cordier, L'abri des Corréardes à Lus-La-Croix-Haute (Drôme): un site de chasse du Néolithique ancien dans la haute vallée du Buëch. In: A. Beeching (Ed.), Circulations et identités culturelles alpines à la fin de la préhistoire. Matériaux pour une étude. Programme CIRCALP 1997-1998. Travaux du Centre d'Archéologie Préhistorique de Valence 2 (Valence 1999) 359-371.

Davies et al. 2003: B. A.S. Davis/S. Brewer/A. C. Stevenson/J. Guiot, The temperature of Europe during the Holocene reconstructed from pollen data. Quaternary Scien. Rev. 22, 2003, 1701-1716.

de Grooth 1991: M. E.T. de Grooth, Socio-economic aspects of Neolithic flint mining: a preliminary study. Helinium 31, 1991, 153-189.

- 2003: -, They do things differently there. Flint working at the Early Bandkeramik settlement of Geleen-Janskamperveld (The Netherlands). In: J. Eckert/U. Eisenhauer/A. Zimmermann (Eds.) Archäologische Perspektiven. Analysen und Interpretationen im Wandel. Festschrift für Jens Lüning zum 65. Geburtstag. Internat. Arch.: Stud. honoraria 20 (Rahden/Westf. 2003) 401-406.

- 2010: -, Das Feuersteinbergwerk von Rijckholt-St. Geertruid (Limburg, Niederlande). In: Badisches Landesmuseum Karlsruhe (Ed.), Jungsteinzeit im Umbruch. Die “Michelsberger Kultur" und Mitteleuropa vor 6000 Jahren Kat. Austell. Badisches Landesmus. Karlsruhe (Darmstadt 2010) 210-211. 
Denaire et al. 2011: A. Denaire/T. Doppler/P.-Y. Nicod/S. van Willingen, Espaces culturels, frontières et interactions au 5 ème millénaire entre la plaine du Rhin supérieur et les rivages de la Méditerranée. Jahrb. Arch Suisse 94, 2011, 21-59.

Denton/Karlen 1973: G. H. Denton/W. Karlén, Holocene climatic variations: their pattern and possible cause. Quaternary Res. 3, 1973, 155-205.

Doppler/Ebersbach 2011: T. Doppler/R. Ebersbach, Grenzenlose Jungsteinzeit? Betrachtungen zur kulturellen Heterogenität im schweizerischen Neolithikum - ein Projektbericht. In: T. Doppler/B. Ramminger/D. Schimmelpfennig (Eds.) Grenzen und Grenzräume? Beispiele aus Neolithikum und Bronzezeit. Fokus Jungsteinzeit. Ber. AG Neolithikum 2 (Kerpen-Loogh 2011) 205-215.

Dubouloz 1998: J. Dubouloz, Réflexions sur le Michelsberg ancien en Bassin parisien. In: J. Biel/H. Schlichtherle/

M. Strobel/A. Zeeb (Eds.), Die Michelsberger Kultur und ihre Randgebiete - Probleme der Entstehung, Chronologie und des Siedlungswesens. Math. z. Arch. Baden-Württemberg 43 (Stuttgart 1998) 9-20.

Ebersbach et al. 2012: R. Ebersbach/M. Kühn/B. Stopp/J. Schibler, Die Nutzung neuer Lebensräume in der Schweiz und angrenzenden Gebieten im 5. Jahrtausend v. Chr. - siedlungsund wirtschaftsarchäologische Aspekte. Jahrb. Arch. Schweiz 95, 2012, 7-34.

Eckmeier et al. 2007: E. Eckmeier/M. Rösch/O. Ehrmann/ M. W. Schmidt/W. Schier/R. Gerlach, Conversion of biomass to charcoal and the carbon mass balance from a slash-and-burn experiment in a temperate deciduous forest. The Holocene 17/4, 2007, 539-542.

Ehrmann/Rösch 2005: O. Ehrmann/M. Rösch, Experimente zum neolithischen Wald-Feldbau in Forchtenberg. Einsatz und Auswirkung des Feuers, Erträge und Probleme des Getreideanbaus. In: Regierungspräsidium Stuttgart Landesamt für Denkmalpflege (Ed.), Zu den Wurzeln europäischer Kulturlandschaft -experimentelle Forschungen. Wissenschaftliche Tagung Schöntal 2002. Tagungsband. Gerhard Lang zum 80. Geburtstag gewidmet. Math. z. Arch. Baden-Württemberg 73 (Stuttgart 2005) 109-140.

Eisenhauer/Daszkiewicz 2003: U. Eisenhauer/M. Daszkiewicz, Bischheimer Siedlungskeramik aus Guntersblum (Rheinland Pfalz). Archäologische und technologische Untersuchungen. Arch. Korrbl. 33, 2003, 167-186.

Ertuğ-Yaras 1997: F. Ertuğ-Yaraş, An ethnoarchaeological study of subsistence and plant gathering in Central Anatolia. Diss. Washington University, Dept. of Anthropology (St. Louis, Missouri 1997).

Fries/Jansen/Niekus 2013: J. E. Fries/D. Jansen/M. J.L. T. Niekus, Fire in a hole! First results of the Oldenburg-Eversten excavation and some notes on Mesolithic hearth pits and hearth-pit sites. In: Niedersächsisches Institut für Historische Küstenforschung (Ed.), Marschenratskolloquium 2011. Aktuelle archäologische Forschungen im Küstenraum der südlichen Nordsee: Methoden - Strategien - Projekte. 10. - 12. Februar 2011, Forum der Ostfriesischen Landschaft, Aurich. Siedlungsu. Küstenforsch. südl. Nordseegebiet 36 (Rahden/Westf. 2013) 99-110.

Furholt/Müller 2011: M. Furholt/J. Müller, The earliest monuments in Europe - architecture and social structures (5000-3000 cal BC). In: M. Furholt/F. Lüth/J. Müller (Eds.), Megaliths and identities. Early monuments and Neolithic societies from the Atlantic to the Baltic. 3rd European Megalithics Studies Group meeting 13th-15th of May at Kiel University. Frühe Monumentalität und soziale Differenzierung 1 (Bonn 2011) 15-32.

-/Lüth/Müller 2011: -/F. Lüth/J. Müller, Megaliths and identities. Early monuments and Neolithic societies from the Atlantic to the Baltic. 3rd European Megalithics Studies Group meeting 13th-15th of May at Kiel University. Frühe Monumentalität und soziale Differenzierung 1 (Bonn 2011).

Gallay 1977: A. Gallay, Le Néolithique moyen du Jura et des plaines de la Saône. Contribution à l'étude des relations ChasseyCortaillod-Michelsberg. Antiqua 6 (Frauenfeld 1977).

Geschichtlicher Atlas von Hessen 1978: Geschichtlicher Atlas von Hessen, Hessisches Landesamt für geschichtliche Landeskunde (Marburg 1978).

Geschwinde/Raetzel-Fabian 2009: M. Geschwinde/D. RaetzelFabian, EWBSL. Eine Fallstudie zu den jungneolithischen Erdwerken am Nordrand der Mittelgebirge. Beitr. z. Arch. Niedersachsen 14 (Rahden/Westf. 2009).

Grau Bitterli/Fierz-Dayer 2011: M.-H. Grau Bitterli/E. Fierz-Dayer (eds), Bevaix/Treytel-À Sugiez: histoire d'un complexe mégalithique néolithique, témoins d'habitats du Campaniforme et du Bronze ancien (Plateau de Bevaix 6). Arch. neuchâteloise 47 (Hauterive 2011).

Godwin 1970: H. Godwin, Sambucus nigra, 6 foot $(\sim 2 \mathrm{~m})$ length of bark rope at Bar Hill, Antonine Wall, C. Scotland. In: J. Wild (Ed.) Textile manufacture in the northern Roman provinces. Cambridge Classical Stud. (Cambridge 1970).

Gross 1990: E. Gross, Entwicklungen der neolithischen Kulturen im west- und ostschweizerischen Mittelland. Die ersten Bauern 1. Pfahlbaufunde Europas (Zürich 1990) 61-72.

Gross-Klee 1998: E. Gross-Klee, Michelsberg: Heterogenität und kulturelle Einbindung in Raum und Zeit. In: J. Biel/ H. Schlichtherle/M. Strobel/A. Zeeb (Eds.), Die Michelsberger Kultur und ihre Randgebiete - Probleme der Entstehung, Chronologie und des Siedlungswesens. Math. z. Arch. BadenWürttemberg 43 (Stuttgart 1998) 249-260.

Haas/Rasmussen 1993: J. N. Haas/P. Rasmussen, Zur Geschichte der Schneitel- und Laubfutterwirtschaft in der Schweiz eine alte Landwirtschaftspraxis kurz vor dem Aussterben. In: Ch. Bromacher, S. Jacomet, J. N. Haas (Eds.), Festschrift Zoller - Beiträge zu Philosophie und Geschichte der Naturwissenschaften, Evolution und Systematik, Ökologie und Morphologie, Geobotanik, Pollenanalyse und Archäobotanik Dissertationes Bot. 196 (Berlin, Stuttgart 1993) 469-489.

Haas et al. 1998: J. N. Haas/I. Richoz/W. Tinner/L. Wick, Synchronous Holocene climatic oscillations recorded on the Swiss Plateau and at timberline in the Alps. The Holocene 8/3, 1998, 301-309.

Hellmann/Bunting/Gaillard 2009: S. Hellmann/M. J. Bunting/ A.-J. Gaillard, Relevant Source Area of Pollen in patchy cultural landscapes and signals of anthropogenic landscape disturbance in the pollen record: A simulation approach. Rev. Palaeobot. Palynology 153, 2009, 245-258.

Herbig/Sirocko 2012: C. Herbig/F. Sirocko, Palaeobotanical evidence for agricultural activities in the Eifel region during the Holocene: plant macro-remain and pollen analyses from sediments of three maar lakes in the Quaternary Westeifel Volcanic Field (Germany, Rheinland-Pfalz). Vegetation Hist. Archaeobot. 22/6, 2013, 447-462. 
Herrmann/Jockenhövel 1990: F.-R. Herrmann/A. Jockenhövel, Die Vorgeschichte Hessens (Stuttgart 1990).

Hinz/Müller 2012: M. Hinz/J. Müller, Siedlung, Grabenwerk, Großsteingrab. Studien zu Gesellschaft, Wirtschaft und Umwelt der Trichterbechergruppen im nördlichen Mitteleuropa. Frühe Monumentalität und soziale Differenzierung 2 (Bonn 2012).

Höhn 2002: B. Höhn, Michelsberger Kultur in der Wetterau. Univforsch. prähist. Arch. 87 (Bonn 2002).

Höltkemeier/Fetsch in prep.: S. Höltkemeier/S. Fetsch, Faunenanalysen als Interpretationsansätze zur Funktion michelsbergzeitlicher Erdwerke - Am Beispiel der Fundstellen Limburg a. d. Lahn. “Greifenberg” (Kreis Limburg-Weilburg) und Bad Nauheim "Beim Siechenhaus" (Wetteraukreis). In: D. Gronenborn/L. Manolakis/B. Vanmontfort (Eds.) The Michelsberg culture - Territories, resources and sociopolitical complexity? 18th Annual Meeting EAA Helsinki 2012. (RGZM, Mainz in prep.).

Hopf 1981: M. Hopf, Die Pflanzenreste aus Schernau, LDKR. Kitzingen. In: J. Lüning, Eine Siedlung der mittelneolithischen Gruppe Bischheim in Schernau, Ldkr. Kitzingen. Math. z. Bayer. Vorgesch. R. A. 44 (Kallmünz/Opf. 1981).

Hosch/Jacomet 2004: S. Hosch/S. Jacomet, Ackerbau und Sammelwirtschaft. Ergebnisse der Untersuchung von Samen und Früchten. In: S. Jacomet/U. Leuzinger/J. Schibler, Die jungsteinzeitliche Seeufersiedlung Arbon Bleiche 3. Umwelt und Wirtschaft. Arch. Thurgau 12 (Frauenfeld 2004) 112-157.

Jacomet 2007: S. Jacomet, Neolithic plant economies in the northern Alpine Foreland from 5500-3500 cal BC. In: S. Colledge/J. Conolly (Eds.), The origins and spread of domestic plants in southwest Asia and Europe. Publications Inst. Arch. Univ College London. (Walnut Creek 2007) 221-225.

-/Brombacher/Dick 1989: -/C. Brombacher/M. Dick, Archäobotanik am Zürichsee. Ackerbau, Sammelwirtschaft und Umwelt von neolithischen und bronzezeitlichen Seeufersiedlungen im Raum Zürich: Ergebnisse von Untersuchungen pflanzlicher Makroreste der Jahre 1979-1988. Ber. Zürcher Denkmalpfl. Monogr. 7 (Zürich 1989).

-/Schlichtherle 1983: -/ H. Schlichtherle, Der kleine Pfahlbauweizen Oswald Heers - Neue Untersuchungen zur Morphologie neolithischer Nacktweizen-Ähren. In: W. van Zeist/W. A. Casparie (Eds.), Plants and Ancient Man. Studies in palaeoethnobotany : proceedings of the Sixth Symposium of the International Work Group for Palaeoethnobotany, Groningen, 30 May-3 June 1983 (Rotterdam, Boston 1983) 153-176.

Jeunesse 1998: C. Jeunesse, Pour une origine occidentale de la culture de Michelsberg. In: J. Biel/H. Schlichtherle/M. Strobel/A. Zeeb (Eds.), Die Michelsberger Kultur und ihre Randgebiete - Probleme der Entstehung, Chronologie und des Siedlungswesens. Math. z. Arch. Baden-Württemberg 43 (Stuttgart 1998) 29-46.

- 2010: -, Die Michelsberger Kultur. In: Badisches Landesmuseum Karlsruhe (eds), Jungsteinzeit im Umbruch. Die "Michelsberger Kultur” und Mitteleuropa vor 6000 Jahren. Kat. Austell. Badisches Landesmus. Karlsruhe (Darmstadt 2010) 46-55.

-/Lefranc/Denaire 2004: -/P. Lefranc/A. Denaire/ mit Beiträgen von R.-M. Arbogast/G. Naze, Groupe de Bischheim, origine du Michelsberg, genése du groupe d`Entzheim. La transition entre le Néolithique moyen et le Néolithique récent dans les régions Rhénanes. Cahiers Ass. Promotion Recherche Arch. Alsace 18/19 (Riedisheim 2004) 1-280.
-/Seidel 2010: -/U. Seidel, Die Erdwerke. In: Badisches Landesmuseum Karlsruhe (Ed.), Jungsteinzeit im Umbruch. Die “Michelsberger Kultur" und Mitteleuropa vor 6000 Jahren (Karlsruhe 2010) 58-69.

-/van Willigen 2010: -/S. van Willigen, Westmediterranes Frühneolithikum und westliche Linearbandkeramik: Impulse, Interaktionen, Mischkulturen. In: D. Gronenborn/J. Petrasch (Eds.) Die Neolithisierung Mitteleuropas. Internationale Tagung, Mainz 24. bis 26. Juni 2005. RGZM Tagungen 4/2 (RGZM, Mainz 2010) 569-605.

Jöns 2013: H. Jöns, Aktuelle Forschungen zur Besiedlung Nordwestdeutschlands während der Zeit der Trichterbecherkultur. In: Niedersächsisches Institut für Historische Küstenforschung (Ed.), Marschenratskolloquium 2011. Aktuelle archäologische Forschungen im Küstenraum der südlichen Nordsee: Methoden - Strategien - Projekte. 10. - 12. Februar 2011, Forum der Ostfriesischen Landschaft, Aurich. Siedlungs- u. Küstenforsch. südl. Nordseegebiet 36 (Rahden/Westf. 2013) 131-138.

Jones/Rowley-Conwy 2007: G. Jones/P. Rowley-Conwy, On the importance of cereal cultivation in the British Neolithic. In: S. Colledge/J. Conolly (eds), The origins and spread of domestic plant in southwest Asia and Europe. Publications Inst. Arch. Univ College London. (Walnut Creek 2007) 391-421.

Kalis 2010: A. J. Kalis, Umwelt, Klima und Landnutzung im Jungneolithikum. In: Badisches Landesmuseum Karlsruhe (Ed.), Jungsteinzeit im Umbruch. Die “Michelsberger Kultur” und Mitteleuropa vor 6000 Jahren (Karlsruhe 2010) 37-43.

-/Meurers-Balke 1997: -/J. Meurers-Balke, Landnutzung im Neolithikum. In: J. Richter, Neolithikum. Geschichtlicher Atlas Rheinlande II (Köln 1997) 25-47.

-/- 2003: -/-, Zur pflanzensoziologischen Deutung archäobotanischer Befunde. Zwei Pollendiagramme aus dem Wurmtal (Aldenhovener Platte). In: J. Eckert/U. Eisenhauer/A. Zimmermann (Eds.), Archäologische Perspektiven. Analysen und Interpretationen im Wandel. Festschrift für Jens Lüning zum 65. Geburtstag. Internat. Arch. Stud. honoraria 20 (Rahden/Westf. 2003) 251-277.

Kieselbach 1998: P. Kieselbach, Die Silexversorgung in den Michelsberger Erdwerken des Heilbronner Raumes. In: J. Biel/H. Schlichtherle/M. Strobel/A. Zeeb (Eds.), Die Michelsberger Kultur und ihre Randgebiete - Probleme der Entstehung, Chronologie und des Siedlungswesens. Math. z. Arch. Baden-Württemberg 43 (Stuttgart 1998) 101-108.

- 2010: -, Silex. Elementarer Rohstoff und begehrtes Importgut. In: Badisches Landesmuseum Karlsruhe (Ed.), Jungsteinzeit im Umbruch. Die "Michelsberger Kultur" und Mitteleuropa vor 6000 Jahren. Kat. Austell. Badisches Landesmus. Karlsruhe (Darmstadt 2010) 203-209.

Kirleis et al. 2012: W. Kirleis/S. Klooß/H. Kroll/J. Müller, Crop growing and gathering in the Northern German Neolithic: a review supplemented by new results. Vegetation Hist. Archaeobot. 21/3, 2012, 221-242.

Knoche 2008: B. Knoche, mit Beiträgen von H. Berke/J. MeurersBalke/S.Schamuhn, Die Erdwerke von Soest (Kr. Soest) und Nottuln-Uphoven (Kr. Coesfeld). Studien zum Jungneolithikum in Westfalen. Münstersche Beitr. z. Ur- u. Frühgesch. Arch. 3 (Rahden/Westf. 2008).

- 2013a: -, Eine exzeptionelle Jadeitit-Beilklinge aus Soest. In: W. Melzer (Ed.), Neue Forschungen zum Neolithikum in Soest 
und am Hellweg. Soester Beitr. z. Arch. 13 (Soest 2013), 299-314.

- 2013b: -, Zur Chronologie und Typogenese der jungneolithischen Ösenleistenflaschen. In: W. Melzer (Ed.), Neue Forschungen zum Neolithikum in Soest und am Hellweg. Soester Beitr. z. Arch. 13 (Soest 2013), 275-298.

- 2013c: -, Riten, Routen, Rinder - Das jungneolithische Erdwerk von Soest im Wegenetz eines extensiven Viehwirtschaftssystems. In: W. Melzer (Ed.), Neue Forschungen zum Neolithikum in Soest und am Hellweg. Soester Beitr. z. Arch. 13 (Soest 2013) 119-274.

Knörzer 1997: K.-H. Knörzer, Botanische Untersuchungen von 16 neolithischen Siedlungsplätzen im Bereich der Aldenhovener Platter, Kr. Düren und Aachen. In: J. Lüning (Ed.), Studien zur neolithischen Besiedlung der Aldenhovener Platte und ihrer Umgebung. Rheinische Ausgr. 43 (Bonn 1997) 647-684.

-/Meurers-Balke 1999: -/J. Meurers-Balke/with contributions by R. Gerlach/M. Heinen, Die frühholozäne Flora des Rheintales bei Neuss und der Erftaue bei Hombroich. Decheniana, Beih. 38 (Bonn 1999).

Kokabi 2008a: M. Kokabi, Katalog der Tierknochenfunde von Neckarsulm-Obereisesheim “Hetzenberg”, Grabung 1989/90 (überarbeitet und zusammengestellt von Elisabeth Stephan). In: Regierungspräsidium Stuttgart - Landesamt für Denkmalpflege (Ed.), Michelsberger Erdwerke im Raum Heilbronn. Neckarsulm-Obereisesheim “Hetzenberg”, Ilsfeld "Ebene”, Landkreis Heilbronn und Heilbronn-Klingenberg "Schlossberg", Stadtkreis Heilbronn, Band 3: Osteologische Beiträge (Stuttgart 2008) 383-414.

- 2008b: -, Katalog der Tierknochenfunde von HeilbronnKlingenberg “Schloßberg”, Grabung 1986/87 (überarbeitet und zusammengestellt von Elisabeth Stephan). In: Regierungspräsidium Stuttgart - Landesamt für Denkmalpflege (Ed.), Michelsberger Erdwerke im Raum Heilbronn. NeckarsulmObereisesheim “Hetzenberg”, Ilsfeld "Ebene”, Landkreis Heilbronn und Heilbronn-Klingenberg "Schlossberg", Stadtkreis Heilbronn, Band 3: Osteologische Beiträge (Stuttgart 2008) 419-702.

Kreuz 2004/2005: -, Landwirtschaft im Umbruch? Archäobotanische Untersuchungen zu den Jahrhunderten um Christi Geburt in Hessen und Mainfranken. Ber. RGK 85, 2004 (2005) 97-292.

- 2008:-, Closed forest or open woodland as natural vegetation in the surroundings of Linearbandkeramik settlements? Vegetation Hist. Archaeobot. 17,1, 2008, 51-65.

- 2010/2012: -, Die Vertreibung aus dem Paradies? Archäobiologische Ergebnisse zum Frühneolithikum in Mitteleuropa. Ber. RGK 90, 2010 (2012), 23-196.

- 2012: -, Auf den Spuren der Michelsberger Kultur. Internationales archäobotanisches Forschungskolloquium im Schloß Biebrich in Wiesbaden. Denkmalpfl. u. Kulturgesch. 4, 2012, 39.

Kubitz 2000: B. Kubitz, Die holozäne Vegetations- und Siedlungsgeschichte in der Westeifel am Beispiel eines hochauflösenden Pollendiagrammes aus dem Meerfelder Maar. Dissertationes Botanicae 339 (Berlin, Stuttgart 2000).

Kühl/Moschen 2012: N. Kühl/R. Moschen, A combined pollen and \{delta\} 180 Sphagnum record of mid-Holocene climate variability from Dürres Maar (Eifel, Germany). The Holocene 22/10, 2012, 1075-1085.
Kuhlmann 2008: S. Kuhlmann, Die Fundstellen der Bischheimer Gruppe im Frankfurter Stadtgebiet. Hausarbeit zur Erlangung des Magister Artium, Fachbereich 07, Geschichts- und Kulturwissenschaften der Johannes Gutenberg-Universität (Mainz 2008).

Kunst- und Ausstellungshalle Bonn 2013: Auf den Spuren der Irokesen. Kat. Austell. Bonn (Bonn 2013).

Lichardus 1998: J. Lichardus, Die Michelsberger Kultur strukturell gesehen. In: J. Biel/H. Schlichtherle/M. Strobel/A.Zeeb (Eds.), Die Michelsberger Kultur und ihre Randgebiete - Probleme der Entstehung, Chronologie und des Siedlungswesens. Math. z. Arch. Baden-Württemberg 43 (Stuttgart 1998) 261-276.

Litt et al. 2009: T. Litt/C. Schölzel/N. Kühl/A. Brauer, Vegetation and climate history in the Westeifel Volcanic Field (Germany) during the past 11000 years based on annually laminated lacustrine sediments. Boreas 2009, 2009, 679-690.

Louwe Kooijmans 2005: L. Louwe Kooijmans, Hunters become farmers. Early Neolithic B and Middle Neolithic A. In: L. Louwe Kooijmans/P. W. van den Broeke/H. Fokkens/A. L. van Gijn (Eds.), The prehistory of the Netherlands, vol. 2 (Amsterdam 2005) 249-271.

Lüning 1967/1968: J. Lüning, Die Michelsberger Kultur. Ihre Funde in zeitlicher und räumlicher Gliederung. Ber. RGK 48, 1967/1968, 1-350.

- 1972: -, Zum Kulturbegriff im Neolithikum. Prähistorische Zeitschrift 47(2), 1972, 145-173.

- 1981: -, Eine Siedlung der mittelneolithischen Gruppe Bischheim in Schernau, Ldkr. Kitzingen. Math. z. Bayer. Vorgesch. R. A. 44 (Kallmünz/Opf. 1981).

- 1998: -, Betrachtungen über die Michelsberger Kultur. In: J. Biel/H. Schlichtherle/M. Strobel/A. Zeeb (Eds.), Die Michelsberger Kultur und ihre Randgebiete - Probleme der Entstehung, Chronologie und des Siedlungswesens. Math. z. Arch. Baden-Württemberg 43 (Stuttgart 1998) 277-290.

- 2000: -, Steinzeitliche Bauern in Deutschland. Die Landwirtschaft im Neolithikum. Univforsch. prähist. Arch. 58 (Bonn 2000).

Märkle/Rösch 2003: T. Märkle/M. Rösch, Verkohlungsversuche an Kulturpflanzen. In: M. Fansa (Ed.), Experimentelle Archäologie in Europa. Bilanz 2003 (Oldenburg 2003), 73-80.

Magny 2004: M. Magny, Holocene climate variability as reflected by mid-European lake-level fluctuations and its probable impact on prehistoric human settlements. Quaternary Int. 113, 1, 2004, 65-79.

- 2013: -, Orbital, ice-sheet, and possible solar forcing of Holocene lake-level fluctuations in west-central Europe: A comment on Bleicher. The Holocene 23/8, 2013, 1202-1212.

- et al. 2006: -/U. Leuzinger/S. Bortenschlager/J. N. Haas, Tripartite climate reversal in Central Europe 5600-5300 years ago. Quaternary Res. 65, 2006, 3-19.

Maier 1996: U. Maier, Morphological studies of free-threshing wheat ears from a Neolithic site in southwest Germany, and the history of the naked wheats. Vegetation Hist. Archaeobot. 5, 1996, 39-55.

- 1998: -, Der Nacktweizen aus den neolithischen Ufersiedlungen des nördlichen Alpenvorlandes und seine Bedeutung für unser Bild von der Neolithisierung Mitteleuropas. Arch. Korrbl. 28, 1998, 205-218.

-1999: -, Agricultural activities and land use in a Neolithic village around 3900 B. C.: Hornstaad Hörnle I A, Lake Constance, Germany. Vegetation Hist. Archaeobot. 8, 1999, 87-94. 
-/Vogt 2001: -/R. Vogt, Siedlungsarchäologie im Alpenvorland VI. Botanische und pedologische Untersuchungen zur Ufersiedlung Hornstaad-Hörnle IA. Forsch. u. Ber. z. Vor- u. Frühgesch. Baden-Württemberg 74 (Stuttgart 2001).

- 2004: -/mit Beitrag von R. Vogt, Archäobotanische Untersuchungen in jung- und endneolithischen Moorsiedlungen am Federsee. In: H. Schlichtherle (Ed.), Ökonomischer und ökologischer Wandel am vorgeschichtlichen Federsee. Archäologische und naturwissenschaftliche Untersuchungen. Hemmenhofener Scripte 5 (Hemmenhofen 2004) 71-159.

- 2011: -/mit einem Beitrag von Christoph Herbig, Archäobotanische Flächenuntersuchungen in der endneolithischen Siedlung Torwiesen II. In: H. Schlichterle/R. Vogt/U. Maier/ C. Herbig/E. Schmidt/K. Ismail-Meyer/M. Kühn/L. Wick/ A. Dufraisse (Eds.), Die endneolithische Moorsiedlung Bad Buchau-Torwiesen II am Federsee. Band 1: Naturwissenschaftliche Untersuchungen. Hemmenhofener Scripte 9 (Freiburg i. Breisgau 2011) 81-280.

Maise 1998: C. Maise, Archäoklimatologie. Vom Einfluß nacheiszeitlicher Klimavariabilität in der Ur- und Frühgeschichte. Jahrb. Schweizer. Ges. Ur- u. Frühgesch. 81, 1998, 197-235.

Manen et al. 2004: C. Manen/L. Bouby/I. Carrère/J. Coularou/ B. Devillers/C. Muller/T. Perrin/D. Sordoillet/J.-D. Vigne/ J.-L. Voruz, Nouvelles données sur le Néolithique ancien Gardois: résultats des campagnes de fouille 2001-2002 de la Grotte du Taï (Remoulins). In : H. Dartevelle (Ed.), Auvergne et Midi. Actualité de la recherche. Actes des 5e Rencontres Méridionales de Préhistoire Récente, ClermontFerrand (Puy-de-Dôme) 8 et 9 novembre 2002. Préhistoire de Sud-Ouest, suppl. 9 (Cressensac 2004) 321-336.

Marinval 2007: P. Marinval, Premières données sur l'économie végétale. In: J. Guilaine/C. Manen/J.-D. Vigne (Eds.), Pont de Roque-Haute. Nouveaux regards sur la Néolithisation de la France méditerranéenne. Archives d’Écologie Prehist. (Toulouse 2007) 215-217.

- 1988: -, L'alimentation végétale en France du Mésolithique jusqu'à l'Âge du Fer, 1988.

Marolle 1998: C. Marolle, Le site Michelsberg des "Hautes Chanviéres” avec bâtiments et enceinte á Mairy, Ardennes France. In: J. Biel/H. Schlichtherle/M. Strobel/A. Zeeb (Eds.), Die Michelsberger Kultur und ihre Randgebiete - Probleme der Entstehung, Chronologie und des Siedlungswesens. Math. z. Arch. Baden-Württemberg 43 (Stuttgart 1998) 21-28.

Martinoli/Jacomet 2002: D. Martinoli/S. Jacomet, Pflanzenfunde aus Cham-Eslen. Erste Ergebnisse zur Versorgung mit pflanzlichen Nahrungsmitteln. Tugium 18, 2002, 76-77.

Matuschik 2011: I. Matuschik, Die Keramikfunde von Hornstaad Hörnle I-VI. Besiedlungsgeschichte der Fundstelle und Keramikentwicklung im beginnenden 4. Jahrtausend v. Chr. im Bodenseeraum. Siedlungsarchäologie im Alpenvorland XII. Forsch. u. Ber. z. Vor- u. Frühgesch. Baden-Württemberg 122 (Stuttgart 2011).

McClatchie et al. 2013: M. McClatchie; A. Bogaard; S. Colledge; N. J. Whitehouse; R. J. Schulting; P. Barratt; T. R. McLaughlin, Neolithic farming in north-western Europe: archaeobotanical evidence from Ireland. Journal of Archaeological Science 2013, http://dx.doi.org/10.1016/j.jas.2012.10.022.

Meeker/Mayewski 2002: L. D. Meeker/P. A. Mayewski, A 1400-year high-resolution record of atmospheric circulation over the North Atlantic and Asia. The Holocene 12, 257-266.
Meligren 2012: J. Meligren, Flechten mit Naturmaterial faszinierende Körbe, Schalen und mehr (Werkstatt, Stuttgart 2012).

Meyer 1992/1993: M. Meyer, Zur Michelsberger Kultur im nördlichen Hessen. Ber. Komm. Arch. Landesforsch. Hessen 2 (Spangenberg 1992/1993) 19-32.

Moffett/Robinson/Straker 1989: L. Moffett/M. A. Robinson/ V. Straker, Cereals, fruit and nuts: charred plant remains from Neolithic sites in England and Wales and the Neolithic economy. In: A. Milles/D. Williams/N. Gardner (Eds.), The beginnings of agriculture. BAR Internat. Ser. 496 (Oxford 1989) 243-261.

Moinat/Chambon 2007: P. Moinat/P. Chambon (Eds.), Les cistes de Chamblandes et la place des coffres dans les pratiques funéraires du Néolithique moyen occidental. Actes du colloque de Lausanne, 12 et 13 mai 2006. Cahiers arch. Romande 110/ Mémoires de la Société préhistorique française 43 (Lausanne, Paris 2007).

Müller 2010: J. Müller, Dorfanlagen und Siedlungssysteme. Die europäische Perspektive: Südosteuropa und Mitteleuropa. In: Badisches Landesmuseum Karlsruhe (Ed.), Jungsteinzeit im Umbruch. Die “Michelsberger Kultur” und Mitteleuropa vor 6000 Jahren (Karlsruhe 2010) 250-257.

- 2011: -, “Rituelle Kooperation” und “Rituelle Kollektivität”: Zur Sozialstruktur der mittleren und jüngeren TrichterbecherNordgruppe (3500-2800 v. Chr.). In: S. Hansen/J. Müller (Eds.), Sozialarchäologische Perspektiven: Gesellschaftlicher Wandel 5000-1500 v. Chr. zwischen Atlantik und Kaukasus: Internationale Tagung 15-18 Oktober 2007 in Kiel (Darmstadt 2011) 139-150.

Nicod/Coutard 2009 : P.-Y. Nicod/C. Coutard, Les céramiques du Néolithique moyen I (couches 52 à 48). In: Voruz, Jean-Louis (Ed.). La grotte du Gardon (Ain) Volume 1 : Le site et la séquence néolithique des couches 60 à 47. Toulouse : Ecole des Hautes études en sciences sociales (Archives d'écologie préhistorique) 2009, 501-536.

Nielsen et al. 2012: A. B. Nielsen/T. Giesecke/M. Theuerkauf/ I. Feeser/K.-E. Behre/H.-J. Beug/S.-H. Chen/J. Christiansen/ W. Dörfler/E. Endtmann/S. Jahns/P. de Klerk/N. Kühl/ M. Latałowa/B. V. Odgaard/P. Rasmussen/J. R. Stockholm/ R. Voigt/J. Wiethold/S. Wolters, Quantitative reconstructions of changes in regional openness in north-central Europe reveal new insights into old questions. Quaternary Scien. Rev. 47, 2012, 131-149.

Nisbet 2008: R. Nisbet, Wood use and agriculture at Villandro/ Villanders (Bolzano/Bozen, Alto Adige/South Tirol): the charred remains from Mesolithic to Middle Ages. Atti della Società per la preistoria e protostoria della regione Friuli-Venezia Gulia 16, 2008 (Trieste 2008) 75-131.

Nussbaumer/Steinhilber/Trachsel/Breitenmoser/Beer/Blass/ Grosjean/Hafner/Holzhauser/Wanner/Zumbühl 2011: S. U. Nussbaumer/F. Steinhilber/M. Trachsel/P. Breitenmoser/J. Beer/A. Blass/M. Grosjean/A. Hafner/H. Holzhauser/H. Wanner/H. J. Zumbühl, Alpine climate during the Holocene: a comparison between records of glaciers, lake sediments and solar activity. Journal Quaternary Scien. 16/7, 2011, 703-713.

Päffgen/Zerl 2005: B. Päffgen/T. Zerl, Das Michelsberger Erdwerk von Geuenich (Inden 9). Neue Ausgrabungen und archäobotanische Untersuchungen. Arch. Rheinland 2004 (2005) 50-52. 
Pena-Chocarro et al. 2005: L. Pena-Chocarro/L. Zapata Pena/ J. García Gazólaz/M. Gonzáles Morales/J. Sesma /L. G. Straus, The spread of agriculture in northern Iberia: new archaeobotanical data from El Mirón cave (Cantabria) and the open-air site of Los Cascajos (Navarra). In: R. Buxó/S. Jacomet/ F. Bittmann (Eds.), Interaction between Man and Plants. New Progress in Archaeobotanical Research. Proceeding of the 13th IWGP Symposium Girona, Spain, 2004. Vegetation Hist. Archaeobot. 14/4 (Heidelberg 2005) 268-278.

Pétrequin/Cassen/Klassen 2010: P. Pétrequin/S. Cassen/L. Klassen, Zwischen Atlantik und Schwarzem Meer. Die großen Beile aus alpinem Jadeit im 5. und 4. Jahrtausend v. Chr. In: Badisches Landesmuseum Karlsruhe (Ed.), Jungsteinzeit im Umbruch. Die “Michelsberger Kultur" und Mitteleuropa vor 6000 Jahren (Karlsruhe 2010) 191-197.

- et al. 2012: -/-/M. Errera/L. Klassen/A. Sheridan/

A.-M. Pétrequin, Jade. Grandes haches alpines du Néolithique européen. Ve et IVe millénaires avant J.-C; 2 Bände. Cahiers Maison Scien. Homme Claude Nicolas Ledoux, 17, Sér. «Dynamiques territoriales» 6 (Besançon 2012).

Preuß 1998: J. Preuß, Das Neolithikum in Mitteleuropa. Kulturen Wirtschaft - Umwelt vom 6. bis 3. Jahrtausend v. u. Z. Übersichten Zum Stand Der Forschung. Bd 1/1, Teil A: Das Neolithikum in Mitteleuropa (Weissbach 1998).

Probst 1991: E. Probst, Deutschland in der Steinzeit. Jäger, Fischer und Bauern zwischen Nordseeküste und Alpenraum (München 1991).

Rackham 2003: O. Rackham, Ancient woodland. Its history, vegetation and uses in England, $2^{\text {nd }}$ ed. (Kirkcudbrightshire 2003).

Rademacher 1991: R. Rademacher, Spuren einer Siedlung der mittleren Jungsteinzeit im "Hinterweil" in Sindelfingen. In: Stadtarchiv Sindelfingen (Ed.), Sindelfinger Fundstücke - von der Steinzeit bis zur Gegenwart. Stadtarchiv Sindelfingen Veröff. 1, 1991, 17-22.

Raetzel-Fabian 2006: D. Raetzel-Fabian, Rezension: Birgit Höhn, Michelsberger Kultur in der Wetterau. Univforsch. prähist. Arch. 87 (Bonn 2002). Germania 84, 2006, 177-182.

Ramminger 2010: B. Ramminger, Kommunikationsanzeigende Netzwerke. Beile und Äxte. In: Badisches Landesmuseum Karlsruhe (Ed.), Jungsteinzeit im Umbruch. Die “Michelsberger Kultur” und Mitteleuropa vor 6000 Jahren. Kat. Austell. Badisches Landesmus. Karlsruhe (Darmstadt 2010) 198-202.

Regner-Kamlah 2010: B. Regner-Kamlah, Bevorzugte Höhenlage: Michelsberger Erdwerke im Bruchsaler Raum. In: Badisches Landesmuseum Karlsruhe (Ed.), Jungsteinzeit im Umbruch. Die “Michelsberger Kultur" und Mitteleuropa vor 6000 Jahren (Karlsruhe 2010) 70-71.

Richter in prep.: N. Richter, Der Kapellenberg bei Hofheim a. T. Eine michelsbergzeitliche Höhensiedlung und ihr Umland. Unveröffentlichte Inauguraldissertation. Johannes-GutenbergUniversität Mainz (Mainz 2010), Materialien zur Vor- und Frühgeschichte von Hessen, (Wiesbaden) in prep.

Rigert et al. 2005: E. Rigert/I. Ebneter/R. Ebersbach/Ö. Akeret/

U. Leuzinger, Die Epi-Rössener Siedlung von Sevelen

SG-Pfäfersbüel. Jahrb. Schweizer. Ges. Ur- u. Frühgesch. 88, 2005, 41-86.

Rösch 2012: M. Rösch, Vegetation und Waldnutzung im Nordschwarzwald während sechs Jahrtausenden anhand von Profundalkernen aus dem Herrenwieser See. Standort.Wald,
Mitt. Ver. forstl. Standortskde u. Forstpflanzenzüchtung 47, 2012, 43-64.

- 2013: -, Pflanzliche Großreste aus Schichten der Schussenrieder und Pfyn-Altheimer Kultur aus dem Steeger See, Stadt Aulendorf, Landkreis Ravensburg. Fundber. Baden-Württemberg 33, 2013, 7-35.

- 2014: -, Pflanzenreste vom Viesenhäuser Hof, Stadtteil Mühlhausen, Stuttgart. Fundberichte aus Baden-Württemberg 34/1, 2014, 143-176.

- et al. 2011: -/H. Biester/A. Bogenrieder/E. Eckmeier/O. Ehrmann/ R. Gerlach/M. Hall/C. Hartkopf-Fröder/L. Herrmann/B. Kury/ W. Schier/E. Schulz, Spätneolithischer Ackerbau im Experiment - eine Zwischenbilanz nach zwölf Jahren Forchtenberg. In: H.-R. Bork/H. Meller/R. Gerlach (Eds.): Umweltarchäologie - Naturkatastrophen und Umweltwandel im archäologische Befund. 3. Mitteldeutscher Archäologentag vom 07. bis 09. Oktober 2010 in Halle (Saale). Tagungen des Landesmuseums für Vorgeschichte Halle (Saale) 6 (Halle 2011) 175-192.

Roth 2000: G. Roth, Die Gesteinsartefakte des michelsbergzeitlichen Erdwerkes “Auf der Alteburg”, Gemeinde Ranstadt-Dauernheim, Wetteraukreis (Grabungen 1991 und 1995). Unpubl. Magisterarbeit im Fach Ur- und Frühgeschichte Philosophische Fakultät der Universität zu Köln (Köln 2000).

Rottoli/Castiglioni 2009: M. Rottoli/E. Castiglioni, Prehistory of plant growing and collecting in Northern Italy, based on seed remains from the Early Neolithic and Chalcolithic (c. 5600-2100 cal B. C.). In: S. Jacomet/K. Oeggl (Eds.), Palaeoethnobotany at the time of the Tyrolean Iceman. Vegetation Hist. Archaeobot. 18, 2009, 91-103.

Schäfer 1996: M. Schäfer, Pollenanalysen an Mooren des Hohen Vogelsberges (Hessen) - Beiträge zur Vegetationsgeschichte und anthropogenen Nutzung eines Mittelgebirges. Dissertationes Bot. 265 (Berlin, Stuttgart 1996) 3-280.

Schamuhn in prep.: S. Schamuhn, Hambach 502 und Koslar $10-$ Der Beginn des Jungneolithikums im Rheinland. Arch. Inf. (in prep.).

-/Meurers-Balke 2008: -/J. Meurers-Balke, Verkohlte Früchte und Samen aus dem Michelsberger Grabenwerk in der Soester Altstadt. In: B. Knoche, Die Erdwerke von Soest, Kreis Soest und Nottuln-Uphofen, Kreis Coesfeld. Studien zum Jungneolithikum in Westfalen. Münstersche Beitr. z. Ur- u. Frühgesch. Arch. 3 (Rahden/Westf. 2008) 255-258.

Schibler et al. 1997: J. Schibler/S. Jacomet/H. Hüster-Plogmann/ C. Brombacher, Economic crash during the 37 th and $36^{\text {th }}$ centuries BC. Neolithic lakeshore sites in Switzerland. Anthropozoologica 25/26, 1997, 553-570.

Schier 1993: W. Schier, Das westliche Mitteleuropa an der Wende vom 5. zum 4. Jahrtausend: Kulturwandel durch Kulturkontakt. In: A. Lang/H. Parzinger/H. Küster (Eds.), Kulturen zwischen Ost und West. Das Ost-West-Verhältnis in vor- und frühgeschichtlicher Zeit und sein Einfluss auf Werden und Wandel des Kulturraums Mitteleuropa. Georg Kossack zum 70. Geburtstag am 25. Juni 1993. (Berlin 1993) 19-59.

- 2009: -, Extensiver Brandfeldbau und die Ausbreitung der neolithischen Wirtschaftsweise in Mitteleuropa und Südskandinavien am Ende des 5. Jahrtausends v. Chr. Praehist. Zeitschr. 84 (Berlin 2009) 15-43.

Schlenker 2008: B. Schlenker, Die Knochen- und Geweihartefakte aus dem jungneolithischen Erdwerk von Heilbronn-Klingen- 
berg. Ein Beitrag zur Funktionsanalyse prähistorischer Gerätfunde. In: Regierungspräsidium Stuttgart - Landesamt für Denkmalpflege (Ed.), Michelsberger Erdwerke im Raum Heilbronn, Neckarsulm-Obereisesheim “Hetzenberg”, Ilsfeld "Ebene", Landkreis Heilbronn und Heilbronn-Klingenberg “Schlossberg”, Stadtkreis Heilbronn, Band 3: Osteologische Beiträge (Stuttgart 2008) 9-130.

Schlichtherle 1981: H. Schlichtherle, Cruciferen als Nutzpflanzen in neolithischen Ufersiedlungen Südwestdeutschlands und der Schweiz. Zeitschr. Arch. 15, 1981, 113-124.

- 1988: -, Das Jung- und Endneolithikum in Baden-Württemberg. Zum Stand der Forschung aus siedlungsarchäologischer Sicht. In: D. Planck (Ed.), Archäologie in Württemberg. Ergebnisse und Perspektiven archäologischer Forschung von der Altsteinzeit bis zur Neuzeit (Stuttgart 1988) 91-110.

- 1998: -, Was sucht Michelsberg in den Ufersiedlungen des Bodensees. In: J. Biel/H. Schlichtherle/M. Strobel/A. Zeeb (Eds.), Die Michelsberger Kultur und ihre Randgebiete Probleme der Entstehung, Chronologie und des Siedlungswesens. Math. z. Arch. Baden-Württemberg 43 (Stuttgart 1998) 169-176.

Schreurs 1992: J. Schreurs, The Michelsberg site MaastrichtKlinkers: a functional interpretation. Analecta Praehistorica Leidensia 25 (Leiden 1992) 129-172.

Seidel 2008: U. Seidel, Michelsberger Erdwerke im Raum Heilbronn. Neckarsulm-Obereisesheim "Hetzenberg”, Ilsfeld "Ebene", Landkreis Heilbronn und Heilbronn-Klingenberg "Schlossberg", Stadtkreis Heilbronn. Math. z. Arch. BadenWürttemberg Bd. 81/1; 81/2; 81/3 (Stuttgart 2008).

- 2010: -, Satelliten der Erdwerke? Die unbefestigten Siedlungen der Michelsberger Kultur. In: Badisches Landesmuseum Karlsruhe (Ed.), Jungsteinzeit im Umbruch. Die “Michelsberger Kultur" und Mitteleuropa vor 6000 Jahren. Kat. Austell. Badisches Landesmus. Karlsruhe (Darmstadt 2010) 82-87.

- 2011: -, Oberderdingen-Grossvillars, Lkr. Karlsruhe, eine Siedlungsstelle des Bischheimer Horizonts und der Michelsberger Kultur. In: A. Denaire/C. Jeunesse/P. Lefranc (Eds.), Nécropoles et enceintes danubiennes du Ve millénaire dans le Nord-Est de la France et le Sud-Ouest de l'Allemagne. Actes de la table ronde internationale de Strasbourg 2. 6. 2010, organisée par l' UMR 7044 (CNRS et Université de Strasbourg). Rhin, Meuse, Moselle. Monogr. Arch. Grand Est (Strasbourg 2011) 143-158.

- 2012: -, Wechselnde Überlieferungsdichten von Fundstellen an der Wende vom 5. zum 4. Jahrtausend v. Chr. - am Beispiel der Michelsberger Besiedlung im nördlichen Baden-Württemberg. In: R. Gleser/V. Becker (Eds.), Mitteleuropa im 5. Jahrtausend vor Christus. Beiträge zur Internationalen Konferenz in Münster 2010. Neolithikum und ältere Metallzeiten. Stud. u. Materialien 1 (Berlin 2012) 291-307.

Seifert 2004: M. Seifert, Schellenberg Borscht IV. Ein prähistorischer Siedlungsplatz im Fürstentum Liechtenstein. Die Funde aus Hirschgeweih, Knochen, Felsgestein, Silex und Bergkristall (Triesen 2004).

- 2012: -, Zizers GR-Friedau - mittelneolithische Siedlung mit Hinkelsteinkeramik im Bündner Alpenrheintal. In: A. BoschettiMarardi/A. de Capitani/S. Hochuli/U. Niffeler (Eds.), Form, Zeit und Raum. Grundlagen für eine Geschichte aus dem Boden (Festschrift Werner Stöckli zum 65. Geburtstag). Antiqua. Veröff. Arch. Schweiz 50 (Basel 2012) 79-94.
Siebenmorgen/Lichter 2010: H. Siebenmorgen/C. Lichter, Das Badische Landesmuseum und die Michelsberger Kultur. In: Badisches Landesmuseum Karlsruhe (Ed.), Jungsteinzeit im Umbruch. Die "Michelsberger Kultur" und Mitteleuropa vor 6000 Jahren. Kat. Austell. Badisches Landesmus. Karlsruhe (Darmstadt 2010) 15-23.

Stephan 2008a: E. Stephan, Die Tierknochenfunde aus den Michelsberger Erdwerken von Neckarsulm-Obereisesheim "Hetzenberg" und Heilbronn-Klingenberg "Schloßberg”. In: Regierungspräsidium Stuttgart - Landesamt für Denkmalpflege (Ed.), Michelsberger Erdwerke im Raum Heilbronn, Band 3: Osteologische Beitr. (Stuttgart 2008) 131-382.

- 2008b: -, Katalog der Tierknochenfunde von NeckarsulmObereisesheim “Hetzenberg”, Grabung1989/90: Nachbestimmungen. In: Regierungspräsidium Stuttgart Landesamt für Denkmalpflege (Ed.), Michelsberger Erdwerke im Raum Heilbronn, Band 3: Osteologische Beiträge (Stuttgart 2008) 415-418.

Steppan 1998: K. Steppan, Archäozoologische Untersuchung der Säugetierreste aus den Gräben der Michelsberger "Erdwerke" in Bruchsal, Landkreis Karlsruhe - Die Bedeutung der Haus- und Wildsäugetiere im Rahmen der jungneolithischen Ernährungswirtschaft in Südwestdeutschland. In: J. Biel/ H. Schlichtherle/M. Strobel/A. Zeeb (Eds.), Die Michelsberger Kultur und ihre Randgebiete - Probleme der Entstehung, Chronologie und des Siedlungswesens. Math. z. Arch. BadenWürttemberg 43 (Stuttgart 1998) 143-151.

- 2003: -, Taphonomie - Zoologie - Chronologie - Technologie Ökonomie. Die Säugetierreste aus den jungsteinzeitlichen Grabenwerken in Bruchsal/Landkreis Karlsruhe. Math. z. Arch. in Baden Württemberg 66 (Stuttgart 2003).

- 2007: -, Wild oder domestiziert? Jungsteinzeitliche Pferde im Alpenvorland. Arch. Deutschland 3, 2007, 26-27.

- 2010: -, Nutztierhaltung und Jagd im Jung- und Spätneolithikum in Südwestdeutschland. In: Badisches Landesmuseum Karlsruhe (Ed.), Jungsteinzeit im Umbruch. Die “Michelsberger Kultur"und Mitteleuropa vor 6000 Jahren (Karlsruhe 2010) 169-172.

Stika 1996a: H.-P. Stika, Cultivated plant remains of the late Neolithic Michelsberg Culture at Heilbronn-Klingenberg (southwest Germany) - a comparison of different features, find assemblages and preservation conditions relating to the representation of archaeobotanical remains. Vegetation Hist. Archaeobot. 5/1-2, 1996, 57-64.

- 1996b: -, Vorgeschichtliche Pflanzenreste aus HeilbronnKlingenberg. Math. Arch. 34 (Stuttgart 1996) 9-128.

Stobbe 1996: A. Stobbe, Die holozäne Vegetationsgeschichte der nördlichen Wetterau - paläoökologische Untersuchungen unter besonderer Berücksichtigung anthropogener Einflüsse. Dissertationes Bot. 260 (Berlin, Stutgart 1996) 1-216.

Strobel 2000: M. Strobel, Die Schussenrieder Siedlung Taubried I (Bad Buchau, Kr. Biberach). Ein Beitrag zu den Siedlungsstrukturen und zur Chronologie des frühen und mittleren Jungneolithikums in Oberschwaben. Forsch. u. Ber. Vor- u. Frühgesch. Baden-Württemberg 81 (Stuttgart 2000).

Thiériot/Saintot 1999: F. Thiériot/S. Saintot/avec la collaboration de A. Urgal, La fosse néolithique du site des Estournelles à Simandres (Rhône). In: A. Beeching (Ed.), Circulations et identités culturelles alpines à la fin de la Préhistoire. Matériaux pour une étude. Programme collectif CIRCALP 1997-1998. 
Travaux Centre d’Arch. Préhist. Valence 2 (Valence 1999) 403-426.

Vanmontfort 2004: B. Vanmontfort, Converging worlds. The Neolithisation of the Scheldt basin during the late fifth and early forth millenium cal BC. Doctoral thesis, Katholieke Universiteit Leuven (Leuven 2004).

- et al. 2001/2002: -/A.-I. Geerts/C. Casseyas/C. Bakels/

C. Buydens/F. Damblon/R. Langohr/W. Van Neer/

P. Vermeersch, De Hel in de tweede helft van het 5 de millenium v. Chr. Een midden-Neolithische enclosure te Spiere (prov. West-Vlaanderen). Arch. Vlaanderen 8, 2001/2002, 9-77.

Vera 2002: F. W.M. Vera, Grazing ecology and forest history (New York repr. 2002).

Vermeersch/Burnez-Lanotte 1998: P. M. Vermeersch/L. BurnezLanotte, La culture de Michelsberg en Belgique: état de la question. In: J. Biel/H. Schlichtherle/M. Strobel/A. Zeeb (Eds.), Die Michelsberger Kultur und ihre Randgebiete - Probleme der Entstehung, Chronologie und des Siedlungswesens. Math z. Arch. Baden-Württemberg 43 (Stuttgart 1998) 47-54.

Villaret-von Rochow 1967: M. Villaret-von Rochow, Frucht- und Samenreste aus der neolithischen Station Seeberg, Burgäschisee-Süd. Acta Bernensia 2/4, 1967, 26-64.

von Merhart 1936: G. von Merhart, Rössener Gefäß vom Gutenberg. Jahrb. Hist. Ver. Fürstentum Liechtenstein 36, 1936, 23-29.

Wahl 2008: J. Wahl, Profan oder kultisch - bestattet oder entsorgt? Die menschlichen Skelettreste aus den Michelsberger Erdwerken von Heilbronn-Klingenberg, NeckarsulmObereisesheim und Ilsfeld. In: Regierungspräsidium Stuttgart - Landesamt für Denkmalpflege (Ed.), Michelsberger Erdwerke im Raum Heilbronn. Neckarsulm-Obereisesheim “Hetzenberg", Ilsfeld "Ebene”, Landkreis Heilbronn und Heilbronn-Klingenberg "Schlossberg", Stadtkreis Heilbronn, Band 3: Osteologische Beiträge (Stuttgart 2008) 703-829.

- 2010: -, Wenige Knochen, viele Fragen. Auf der Suche nach den Menschen der Michelsberger Kultur. In: Badisches
Landesmuseum Karlsruhe (Ed.), Jungsteinzeit im Umbruch. Die “Michelsberger Kultur" und Mitteleuropa vor 6000 Jahren (Karlsruhe 2010) 96-101.

Wanner et al. 2008: H. Wanner/J. Beer/J. Bütikofer/T. J. Crowley/ U. Cubasch/J. Flückiger/H. Goosse/M. Grosjean/F. Joos/ J. O. Kaplan/M. Küttel/S. A. Müller/I. C. Prentice/O. Solomina/ T. F. Stocker/P. Tarasov/M. Wagner/M. Widmann, Mid- to Late Holocene climate change: an overview. Quaternary Scien. Rev. 27/19-20, 2008, 1791-1828.

- et al. 2011: -/O. Solomina/M. Grosjean/S. P. Ritz/M. Jetel, Structure and origin of Holocene cold events. Quaternary Scien. Rev. 30/21-22, 2011, 3109-3123.

Willerding 1986: U. Willerding, Zur Geschichte der Unkräuter Mitteleuropas. Göttinger Schr. z. Vor- u. Frühgesch. 22 (Neumünster 1986).

Winiger 2009: A. Winiger, Le mobilier du Néolithique moyen de Saint-Léonard Sur-le-Grand-Pré (Valais, Suisse). Fouilles Sauter 1956-1962. Cahiers arch. romande 113 (Lausanne 2009).

Wotzka 2000: H.-P. Wotzka, Forschungen zur Siedlungs-, Wirtschafts- und Umweltgeschichte im Niddatal zur Zeit der späten Michelsberger Kultur. Ber. Komm. Arch. Landesforsch. Hessen 5 (Wiesbaden 2000) 27-39.

Wüthrich 2003: S. Wüthrich, Saint-Aubin/Derrière la Croix. Un complexe mégalithique durant le Néolithique moyen et final. Arch. neuchâteloise 29 (Hauterive 2003).

Zeeb-Lanz 2002: A. Zeeb-Lanz, Die Bischheimer Gruppe in der Pfalz. Zugleich ein Beitrag zum Stand der Diskussion um die Chronologie des Übergangs vom Mittel- zum frühen Jungneolithikum in Südwestdeutschland. Mitt. Hist. Ver. Pfalz 100 (Speyer 2002).

Zerl 2003: T. Zerl, Archäobotanische Untersuchungen in Bischheimer Siedlungen aus dem Rheinland und deren Vergleich zu Michelsberger Komplexen Unpubl. Magisterarbeit am Institut für Vor- und Frühgeschichte der J. W. GoetheUniversität Frankfurt a. Main (Frankfurt a. M. 2003). 
نิ่

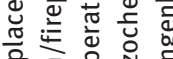

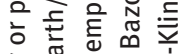

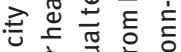

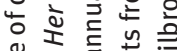
范范

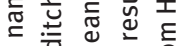
बं 0 है

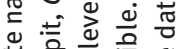

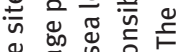

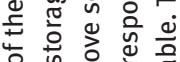

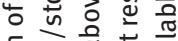

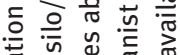
等

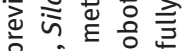

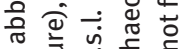
ᄒᄒ जु

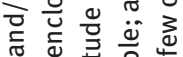

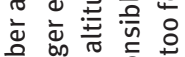

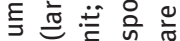

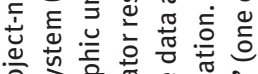
흥 के 든.

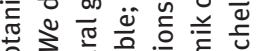

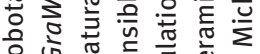

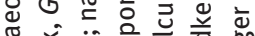

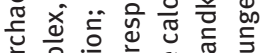

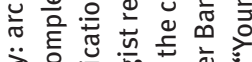

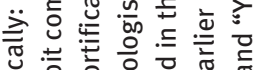

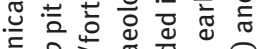
焉 원돈

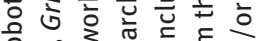

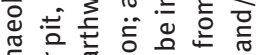

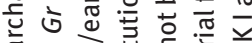

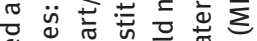

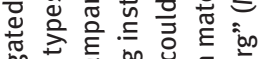
品

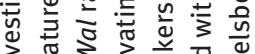

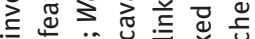

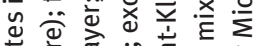

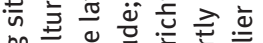

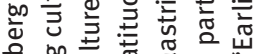

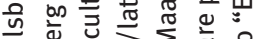
过

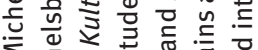
$\sum_{0}$

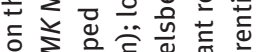

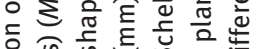

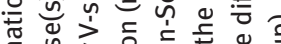

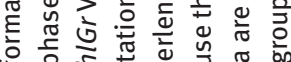

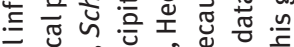

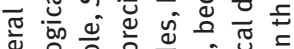

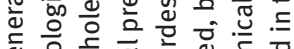
过造卷

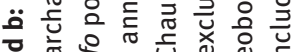

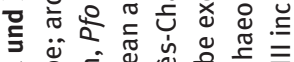

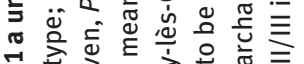

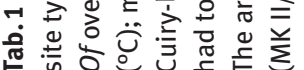

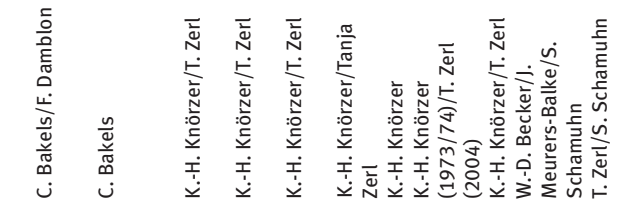

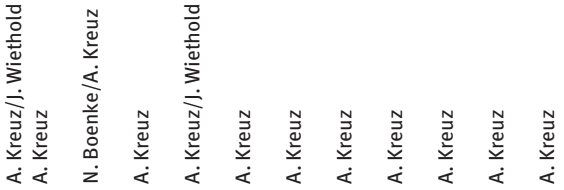

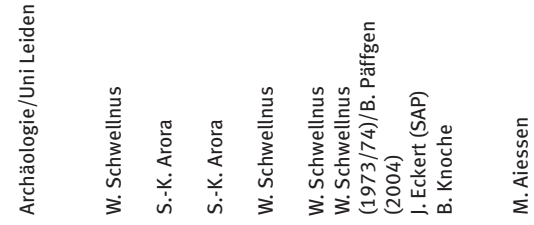

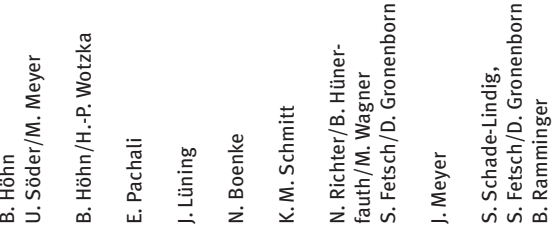

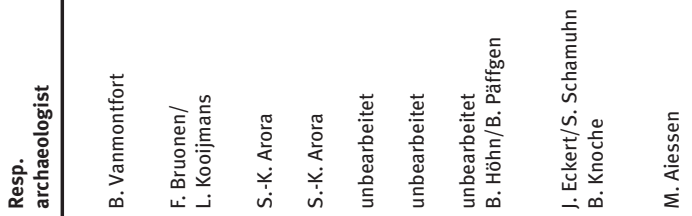

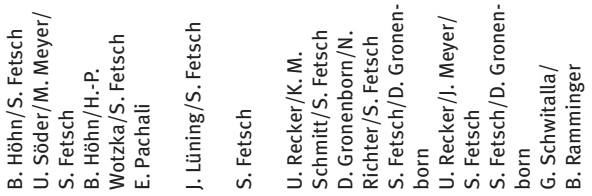

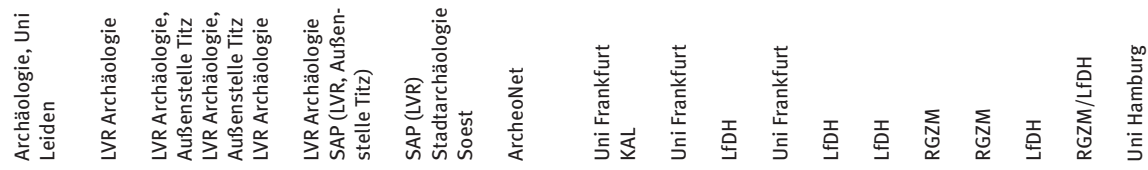

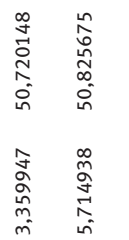

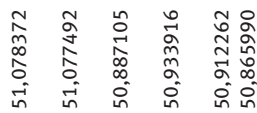

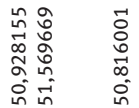

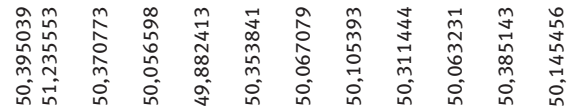

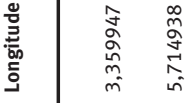

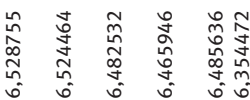

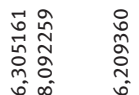

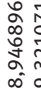

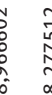

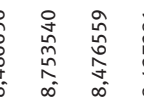

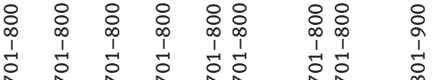

离炬

र下

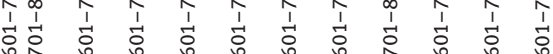

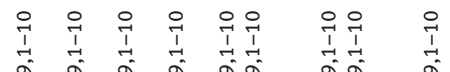

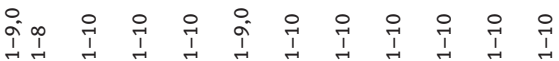

突。

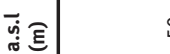

in

$\infty \circ \underset{7}{n} \stackrel{0}{\circ}$

꼬 웅

䒘乲

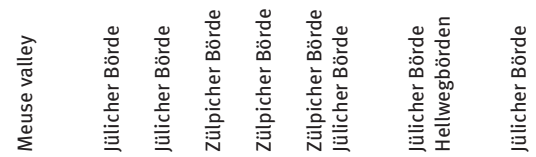

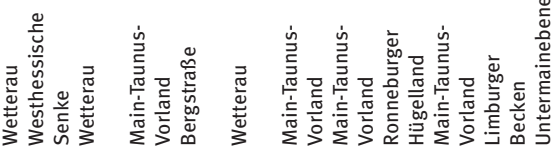

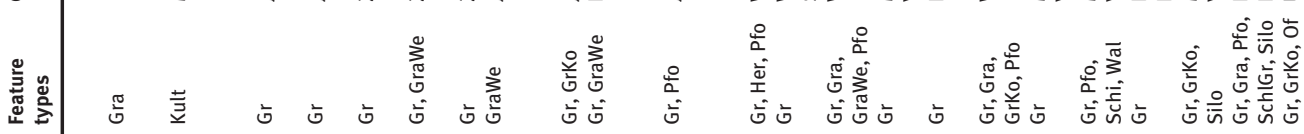

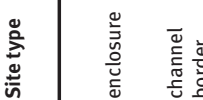

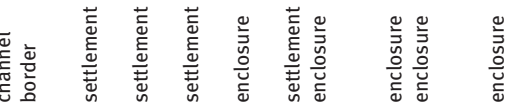

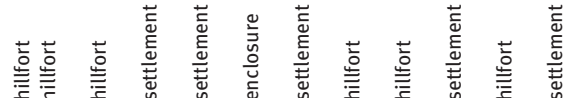

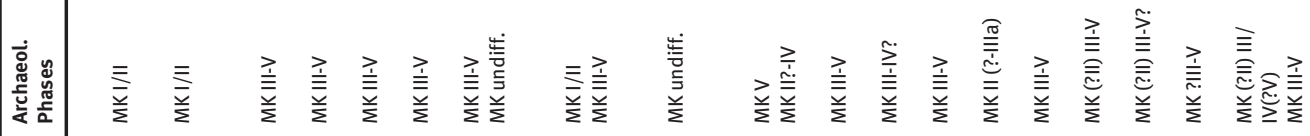

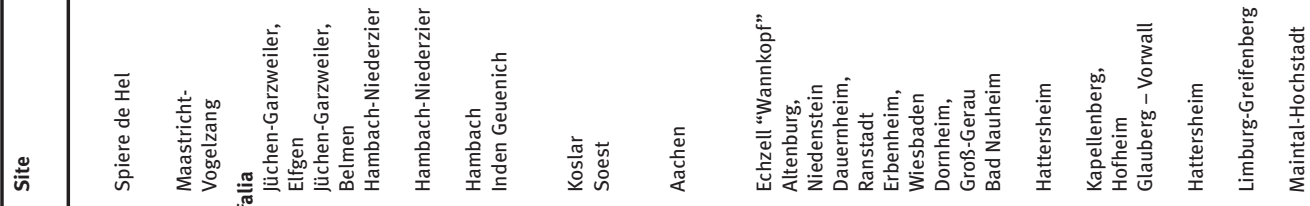

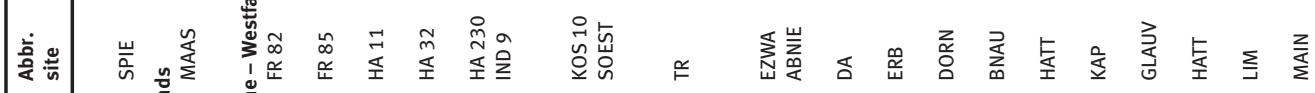

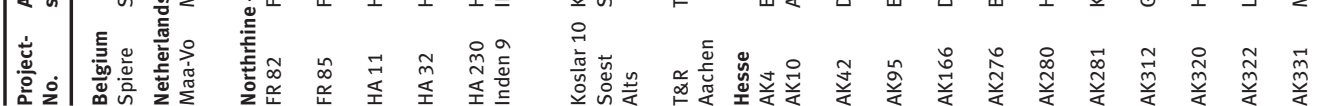




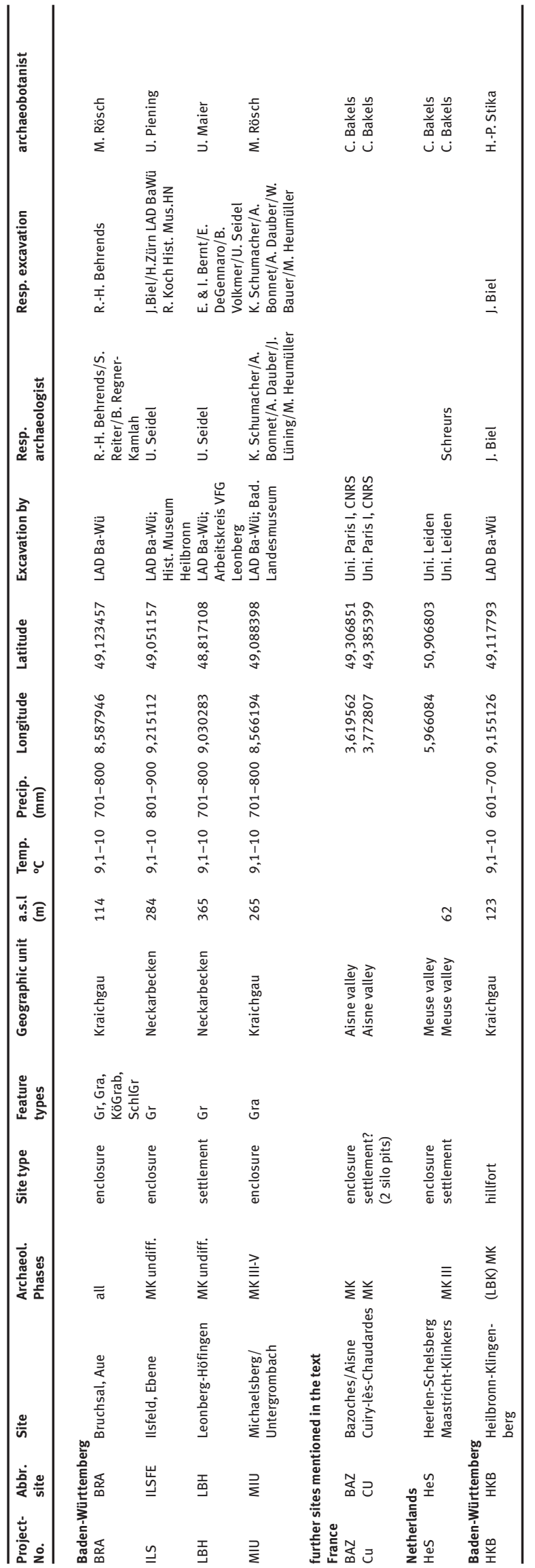


Tab. 2: Database of the 27 Michelsberg sites included in the quantitative evaluations ( $P$ Codes plant codes). Sample volumes are not available at three sites: at Bruchsal and Spiere volumes are partly, at Ilsfeld completely lacking, and so have been (partly) excluded from the calculation of the concentrations

\begin{tabular}{|c|c|c|c|c|c|c|c|c|}
\hline Project & Abbr. & Site name & $\begin{array}{l}\text { Archaeological } \\
\text { dating }\end{array}$ & Features & Samples & $\begin{array}{l}\text { Sample } \\
\text { volume (l) }\end{array}$ & $\begin{array}{l}\text { Plant remains } \\
\text { (without wood) }\end{array}$ & $\begin{array}{l}\text { Number of } \\
\text { taxa (Pcodes) }\end{array}$ \\
\hline AK276 & BNAU & Bad Nauheim & Earlier MK & 6 & 14 & 125,5 & 5.998 & 16 \\
\hline BRA & BRA & Bruchsal & Earlier MK & 2 & 35 & $>5,34$ & 121 & 19 \\
\hline Koslar 10 & KOS 10 & Koslar & Earlier MK & 24 & 95 & 216,95 & 2.465 & 22 \\
\hline Maa-Vo & MAAS & Maastricht, Vogelzang & Earlier MK & 1 & 17 & 121 & 542 & 15 \\
\hline Spiere & SPIE & Spiere de Hel & Earlier MK & 4 & 10 & $>36,6$ & 580 & 14 \\
\hline AK10 & ABNIE & Altenburg, Niedenstein & Younger MK & 4 & 26 & 71,62 & 70 & 11 \\
\hline BRA & BRA & Bruchsal & Younger MK & 3 & 9 & & 27 & 16 \\
\hline AK42 & DA & Dauernheim, Ranstadt & Younger MK & 47 & 187 & $2.523,65$ & 18.202 & 69 \\
\hline AK166 & DORN & Dornheim, Groß-Gerau & Younger MK & 1 & 13 & 143,9 & 338 & 21 \\
\hline AK95 & ERB & Erbenheim, Wiesbaden & Younger MK & 1 & 2 & 0,21 & 24 & 3 \\
\hline AK4 & EZWA & Echzell “Wannkopf” & Younger MK & 10 & 48 & 417,04 & 353 & 14 \\
\hline FR 82 & FR 82 & Jüchen-Garzweiler, Elfgen & Younger MK & 2 & 5 & 41,18 & 689 & 10 \\
\hline FR 85 & FR 85 & Jüchen-Garzweiler, Belmen & Younger MK & 6 & 9 & 16,97 & 1.900 & 12 \\
\hline HA 11 & HA 11 & Hambach-Niederzier & Younger MK & 7 & 26 & 52 & 276 & 13 \\
\hline HA 32 & HA 32 & Hambach-Niederzier & Younger MK & 5 & 10 & 21,00 & 200 & 16 \\
\hline HA 230 & HA 230 & Hambach & Younger MK & 4 & 8 & 9,28 & 106 & 11 \\
\hline AK280 & HATT & Hattersheim & Younger MK & 1 & 1 & 21 & 3 & 3 \\
\hline AK320 & HATT & Hattersheim & Younger MK & 10 & 15 & 115 & 415 & 24 \\
\hline AK322 & LIM & Limburg-Greifenberg & Younger MK & 37 & 50 & 458,5 & 66 & 15 \\
\hline AK331 & MAIN & Maintal-Hochstadt & Younger MK & 5 & 5 & 41 & 530 & 13 \\
\hline MIU & MIU & $\begin{array}{l}\text { Michaelsberg/Untergrom- } \\
\text { bach }\end{array}$ & Younger MK & 1 & 17 & 85,08 & 31 & 10 \\
\hline Soest Alts & SOEST & Soest, Altstadt & Younger MK & 5 & 38 & 212,3 & 175 & 12 \\
\hline BRA & BRA & Bruchsal & MK undiff. & 6 & 91 & $>25,01$ & 377 & 38 \\
\hline AK312 & GLAUV & Glauberg - Vorwall & MK undiff. & 1 & 3 & 50,5 & 82 & 11 \\
\hline ILS & ILSFE & Ilsfeld & MK undiff. & 3 & 3 & & 726 & 2 \\
\hline Inden 9 & IND 9 & Inden Geuenich & MK undiff. & 10 & 19 & 121,05 & 1.481 & 27 \\
\hline AK281 & KAP & Kapellenberg, Hofheim & MK undiff. & 12 & 39 & 158,68 & 10 & 6 \\
\hline LBH & LBH & Leonberg-Höfingen & MK undiff. & 1 & 1 & 10 & 99 & 8 \\
\hline T\&R Aachen & TR & Tank und Rast Aachen & MK undiff. & 9 & 9 & 50,30 & 56 & 7 \\
\hline Sum & & & & 228 & 805 & $5.083,71$ & 35.942 & 113 \\
\hline
\end{tabular}


Tab. 3: Diachronic comparison of frequency values (\% of occurrence per features) from oil-/fibre-plants and pulses. Despite the different numbers of features investigated it is evident, that oil plants and pulses can be preserved in a charred state if they were in use (Bandkeramik/LBK and Middle Neolithic data (Großgartach, Hinkelstein and Rössen) as well as data from younger prehistoric periods from the ArboDat database, Wiesbaden)

\begin{tabular}{|c|c|c|c|c|c|c|c|c|c|}
\hline LBK I & 21 & & & 64 & 57 & 14 & 229 & 1.007 & 18.393 \\
\hline Middle Neolithic & & & & 33 & 33 & 12 & 34 & 199 & 3.439 \\
\hline Michelsberg & & & & 11 & 22 & 27 & 228 & 805 & 5.151 \\
\hline Hallstatt & & 22 & 56 & 44 & 33 & 18 & 84 & 151 & 1.449 \\
\hline Latène & 56 & 20 & 44 & 56 & 60 & 25 & 221 & 639 & 6.471 \\
\hline Roman & 24 & 5 & 39 & 39 & 45 & 38 & 307 & 1.005 & 11.322 \\
\hline Sum & & & & & & 178 & 1.468 & 4.720 & 57.779 \\
\hline
\end{tabular}




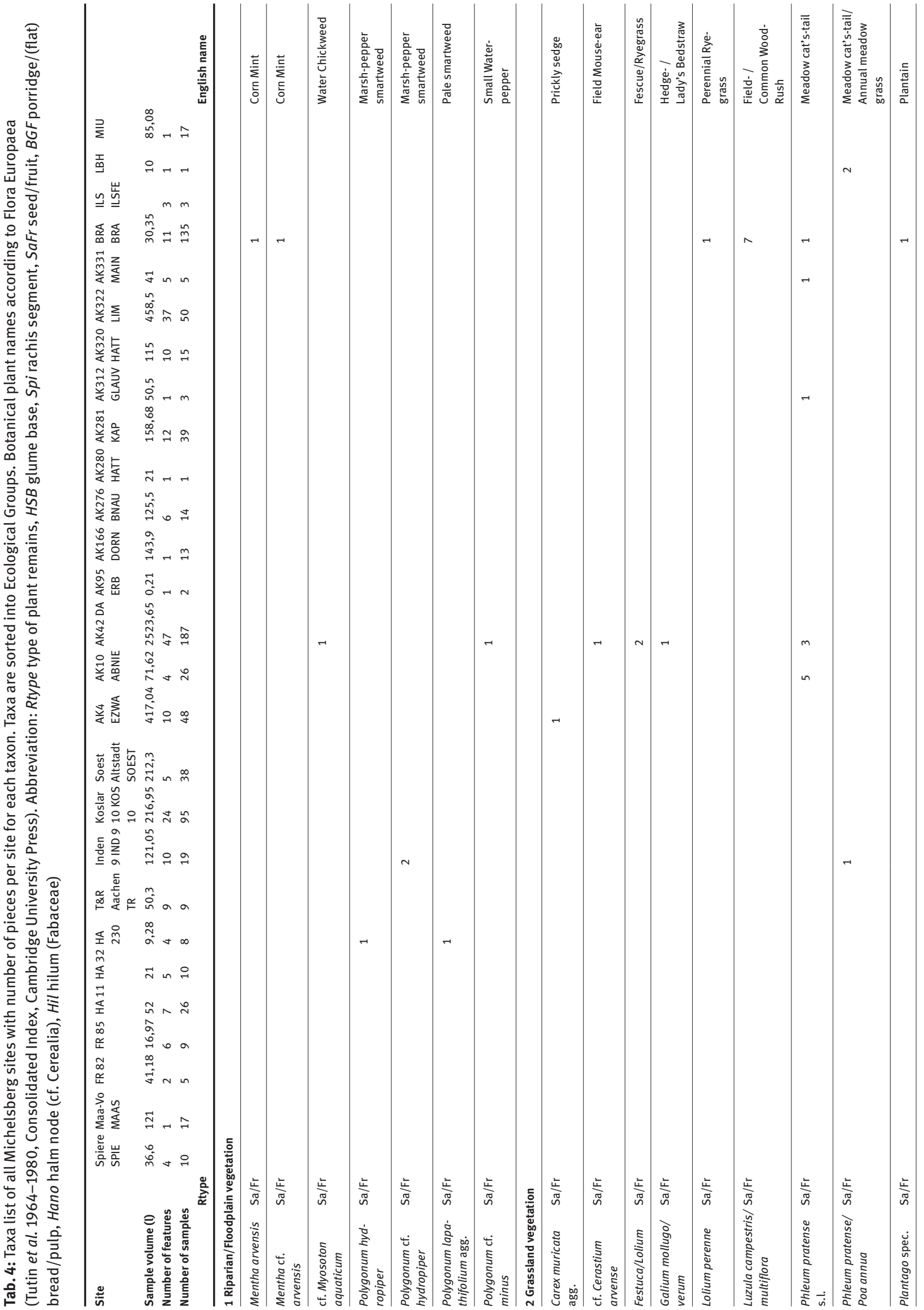




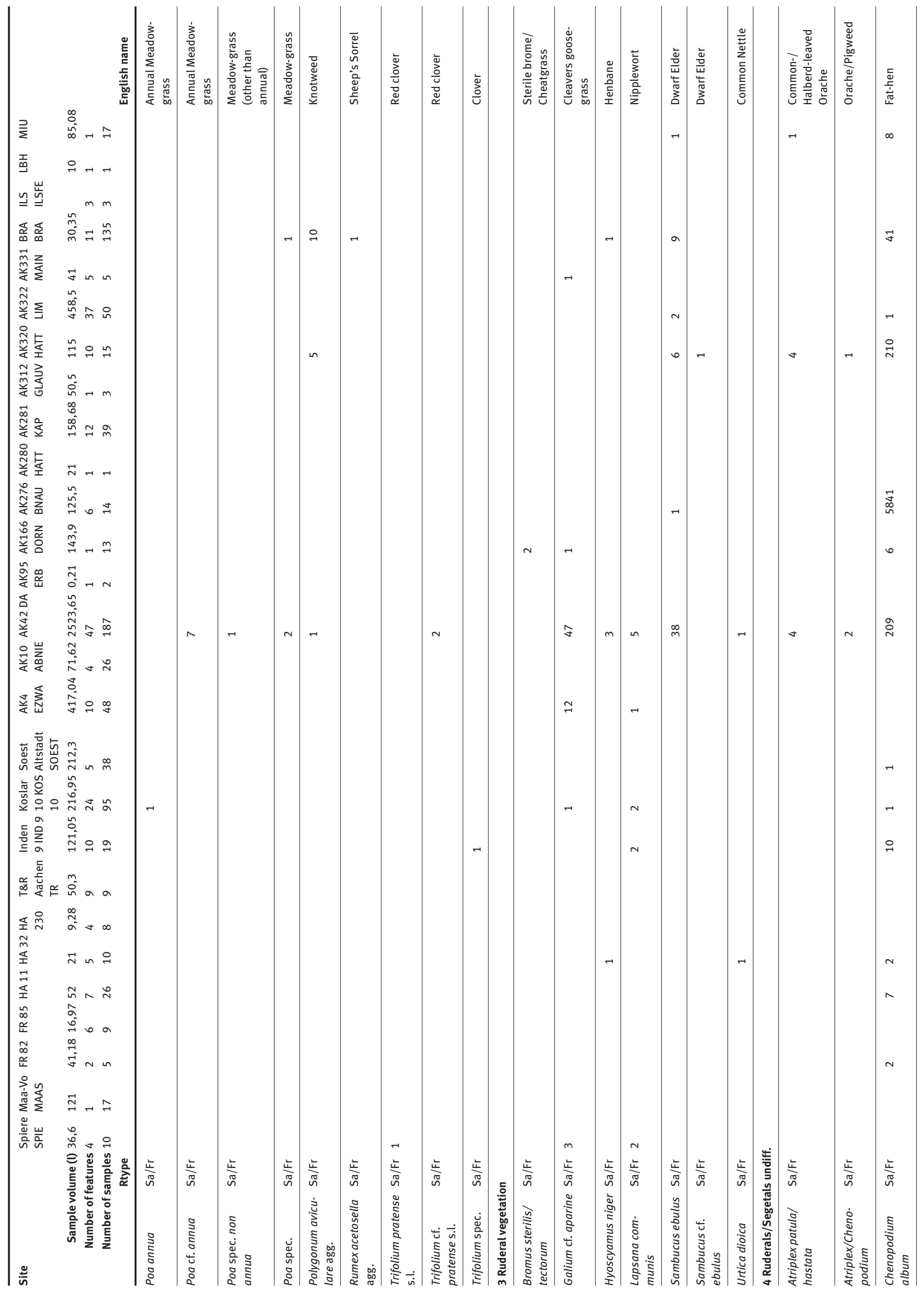




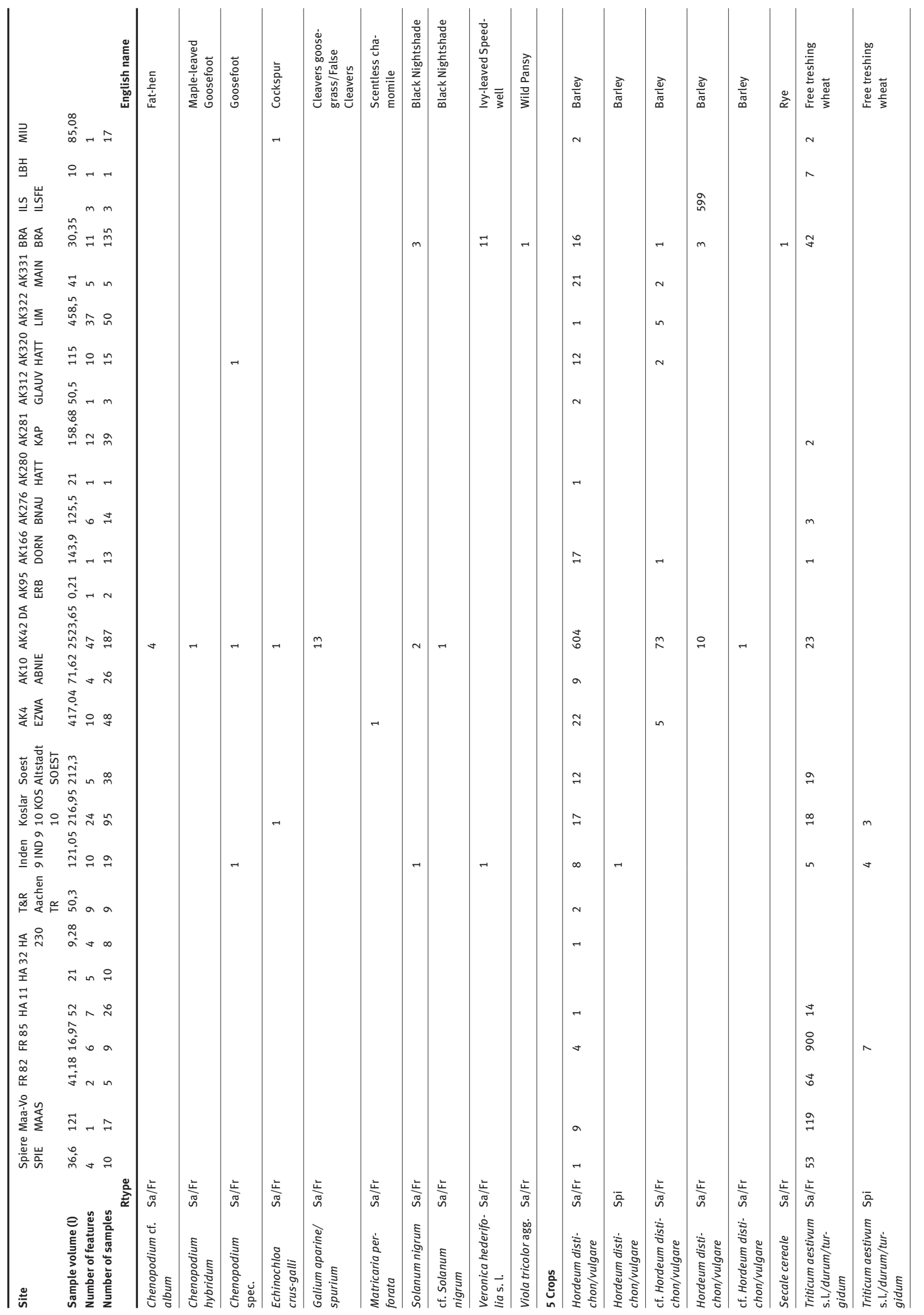




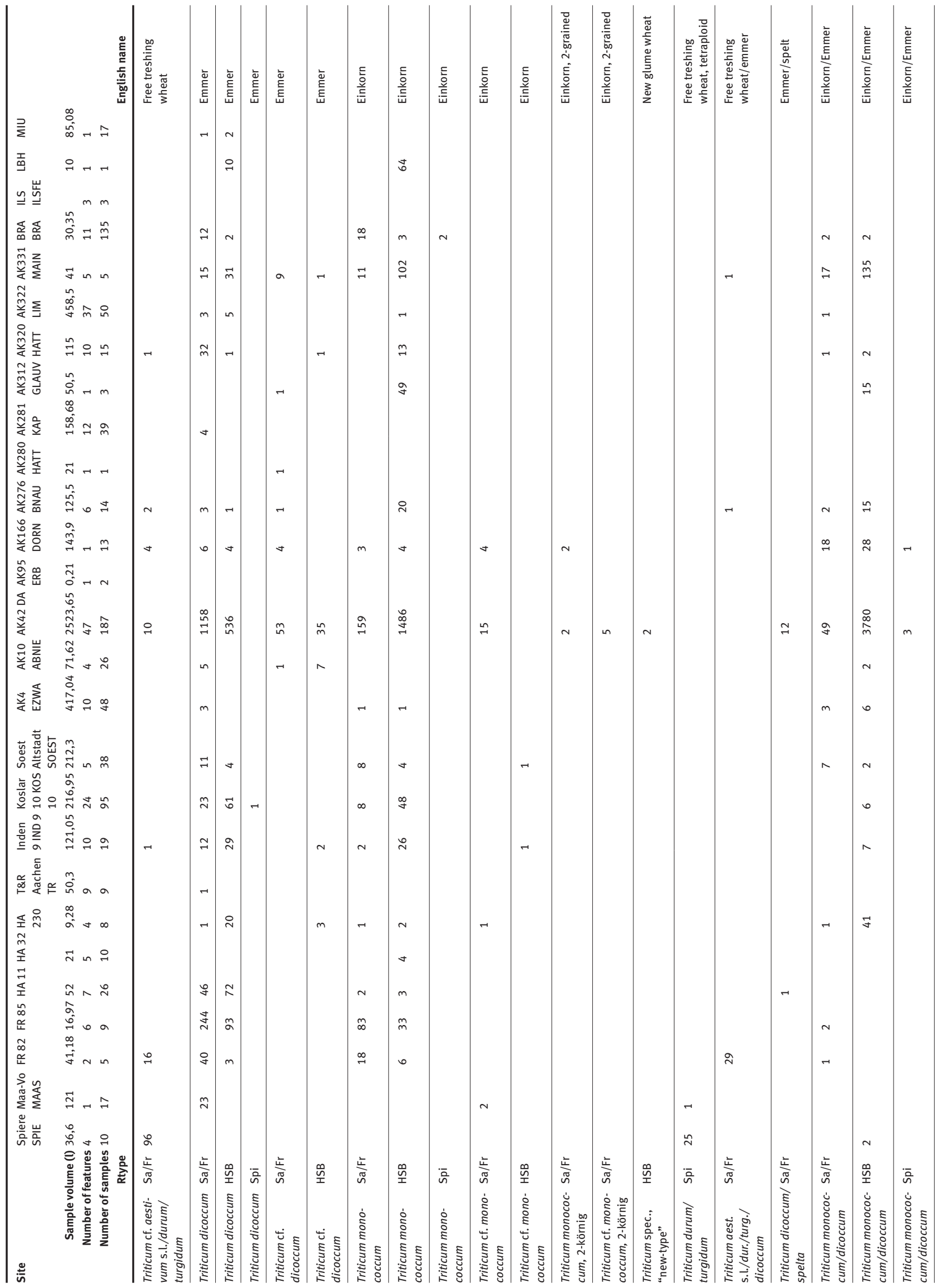




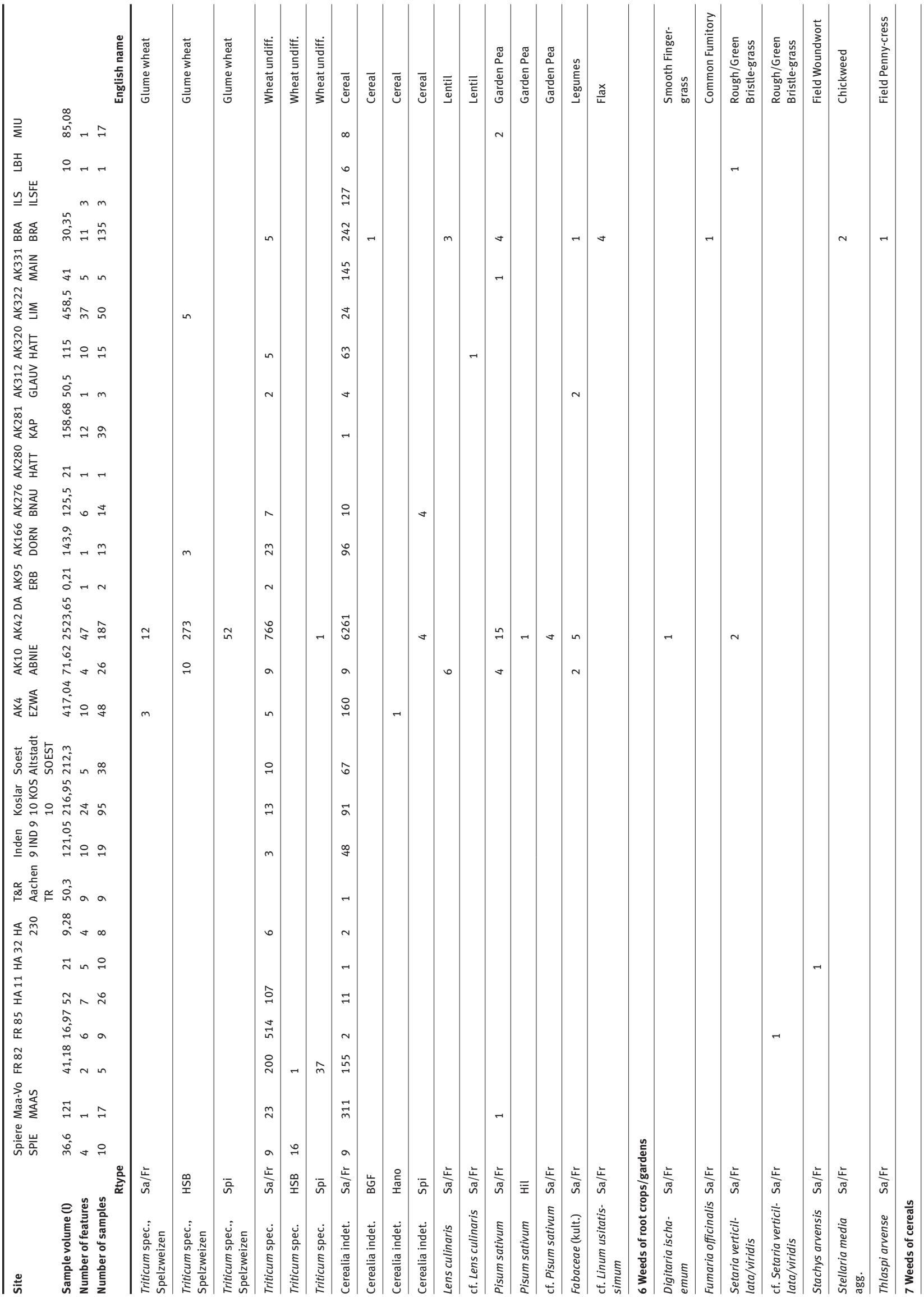




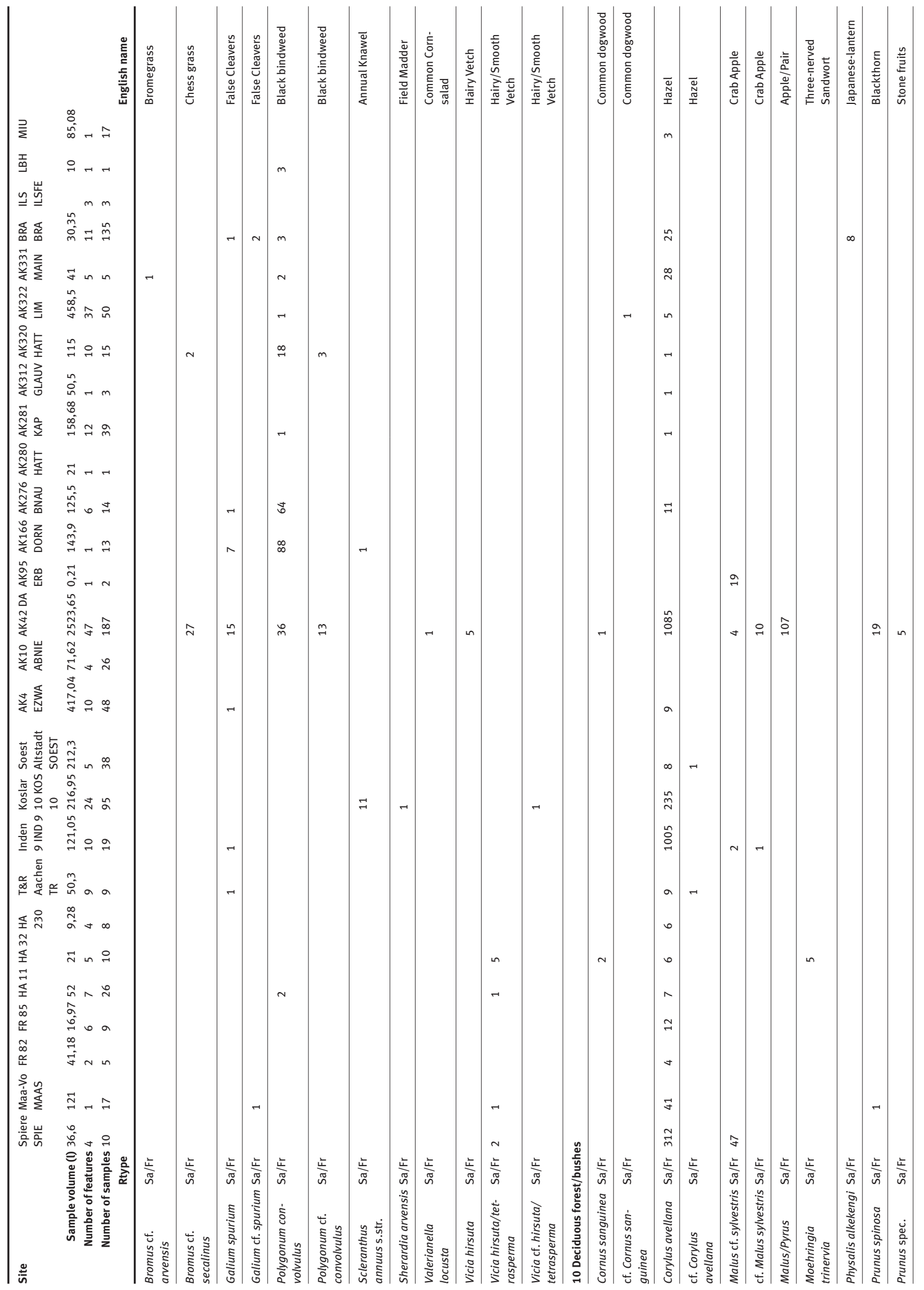




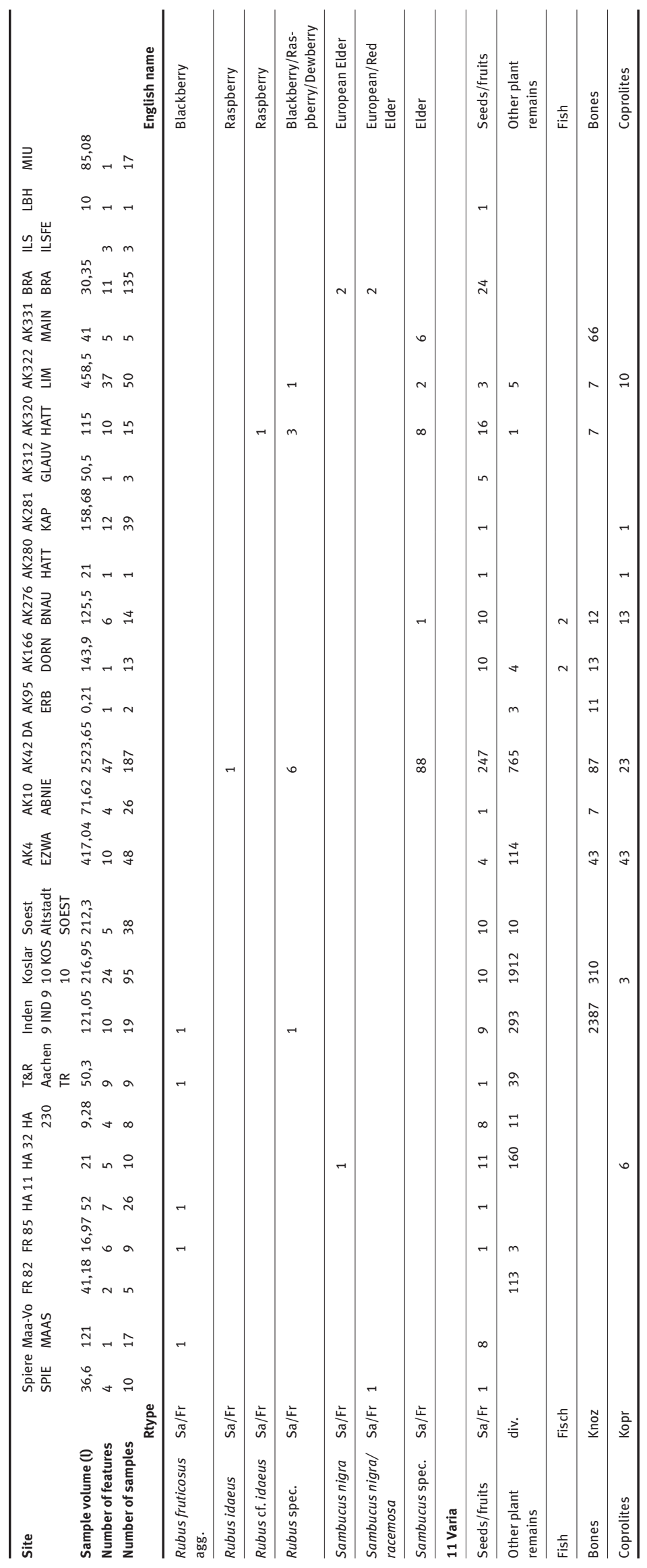

